JULIANA DE PAULA NHANHARELLI

Avaliação da eficácia da terapia com células-tronco renais, oriundas do metanéfro de gato doméstico, no tratamento da doença renal crônica em felinos

São Paulo

2018 


\section{Avaliação da eficácia da terapia com células-tronco renais, oriundas do metanéfro de gato doméstico, no tratamento da doença renal crônica em felinos}

Dissertação apresentada ao

Programa de Pós-Graduação em

Anatomia dos Animais Domésticos e

Silvestres da Faculdade de Medicina

Veterinária e Zootecnia da

Universidade de São Paulo para a obtenção do título de Mestre em Ciências.

Departamento:

Cirurgia

Área de concentração:

Anatomia dos Animais Domésticos e

Silvestres

Orientador:

Profa. Dra. Maria Angélica Miglino

São Paulo

2018 
Autorizo a reprodução parcial ou total desta obra, para fins acadêmicos, desde que citada a fonte.

\section{DADOS INTERNACIONAIS DE CATALOGAÇÃO NA PUBLICAÇÃO}

(Biblioteca Virginie Buff D’Ápice da Faculdade de Medicina Veterinária e Zootecnia da Universidade de São Paulo)

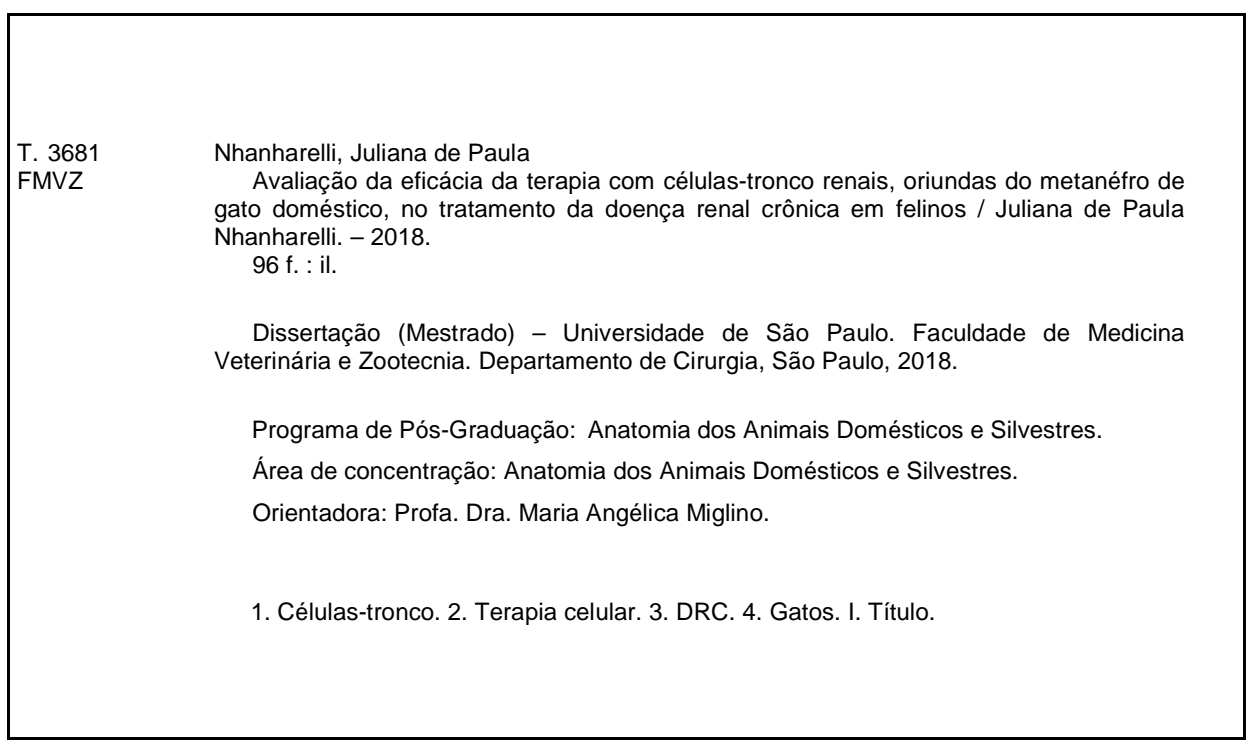

Ficha catalográfica elaborada pela bibliotecária Maria Aparecida Laet, CRB 5673-8, da FMVZ/USP. 


\section{CERTIFICADO}

Certificamos que a proposta intitulada "Avaliação da eficácia da terapia com células tronco renais,oriundas do metanéfro de gato doméstico, no tratamento da doença renal crônica em felinos ", protocolada sob o CEUA no 6673140716 (ID 005084), sob a responsabilidade de Maria Angélica Miglino e equipe; Juliana de Paula Nhanharelli - que envolve a produção, manutenção e/ou utilização de animais pertencentes ao filo Chordata, subfilo Vertebrata (exceto o homem), para fins de pesquisa científica ou ensino - está de acordo com os preceitos da Lei 11.794 de 8 de outubro de 2008, com o Decreto 6.899 de 15 de julho de 2009, bem como com as normas editadas pelo Conselho Nacional de Controle da Experimentação Animal (CONCEA), e foi aprovada pela Comissão de Ética no Uso de Animais da Faculdade de Medicina Veterinária e Zootecnia da Universidade de São Paulo (CEUA/FMVZ) na reunião de 20/06/2018.

We certify that the proposal "Therapy efficacy evaluation with kidney stem cells derived from domestic cat metanephro in the treatment of chronic kidney disease in cats", utilizing 10 Cats (males and females), protocol number CEUA 6673140716 (ID 005084), under the responsibility of Maria Angélica Miglino and team; Juliana de Paula Nhanharelli - which involves the production, maintenance and/or use of animals belonging to the phylum Chordata, subphylum Vertebrata (except human beings), for scientific research purposes or teaching - is in accordance with Law 11.794 of October 8, 2008, Decree 6899 of July 15, 2009, as well as with the rules issued by the National Council for Control of Animal Experimentation (CONCEA), and was approved by the Ethic Committee on Animal Use of the School of Veterinary Medicine and Animal Science (University of São Paulo) (CEUA/FMVZ) in the meeting of 06/20/2018.

Finalidade da Proposta: Pesquisa

Vigência da Proposta: de 11/2016 a 11/2017

Área: Anatomia dos Animais Domésticos E Silvestres

Origem: Não aplicável biotério

Espécie: Gatos sexo: Machos e Fêmeas

idade: 5 a 10 anos

$\mathrm{N}: \quad 10$

Linhagem: todas as raças

Peso: 2 a $5 \mathrm{~kg}$

Local do experimento: Hospital veterinário da Universidade de Santo Amaro (UNISA)

São Paulo, 13 de julho de 2018

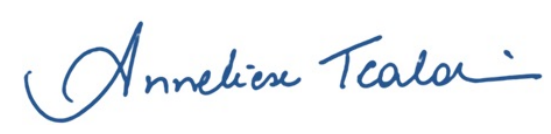

Profa. Dra. Anneliese de Souza Traldi

Presidente da Comissão de Ética no Uso de Animais

Faculdade de Medicina Veterinária e Zootecnia da Universidade de São Paulo

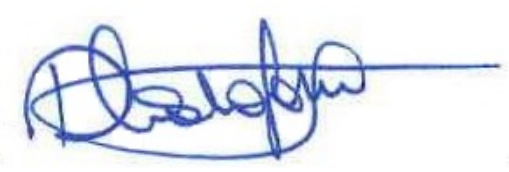

Roseli da Costa Gomes

Secretária

Faculdade de Medicina Veterinária e Zootecnia da Universidade de São Paulo 


\section{FOLHA DE AVALIAÇÃO}

Autor: NHANHARELLI, Juliana de Paula

Título: Avaliação da eficácia da terapia com células-tronco renais, oriundas do metanéfro de gato doméstico, no tratamento da doença renal crônica em felinos

Dissertação apresentada ao Programa de Pós-Graduação em Anatomia dos animais domésticos e Silvestres da Faculdade de Medicina Veterinária e Zootecnia da Universidade de São Paulo para obtenção do título de Mestre em Ciências.

Data:

Banca Examinadora

Prof. Dr.

Instituição: Julgamento:

Prof. Dr.

Instituição: Julgamento:

Prof. Dr. Instituição: Julgamento: 
Dedico este trabalho à minha família 


\section{AGRADECIMENTO}

Agradeço à Professora Maria Angélica Miglino pela oportunidade de fazer minha pós-graduação no setor de Anatomia dos Animais Domésticos FMVZ-USP e também por me ensinar e me ajudar nos momentos em que eu mais precisei.

Às pessoas maravilhosas que conheci nesses dois anos de pós-graduação, que sempre me apoiaram e me orientaram, mas em especial a Lara Carolina Mario, a qual foi a melhor parceira que eu poderia ter e essencial para que tudo desse certo.

Aos meus amigos que entenderam a minha rotina e me ajudaram sempre que preciso, principalmente a Mayara Marjorye, a qual está ao meu lado há 21 anos e mesmo com 6 horas de diferença de fuso horário esteve presente em todos os momentos me dando todo o apoio psicológico que eu precisava.

E o agradecimento final vai para os meus pais Roseli e Amarildo, que investiram no meu futuro, no meu conhecimento e nunca deixam de acreditar em mim, e para o meu irmão João Vitor, o qual é o melhor companheiro e irmão do mundo. 
"É preciso coragem para lembrar que este é um mundo onde nossos sonhos podem se tornar realidade" (Sense 8) 


\section{RESUMO}

NHANHARELLI, J.P. Avaliação da eficácia da terapia com células-tronco renais, oriundas do metanéfro de gato doméstico, no tratamento da doença renal crônica em felinos. 2018. 96f. Dissertação (Mestrado em Ciências) Faculdade de Medicina Veterinária e Zootecnia Universidade de São Paulo, 2018

A doença renal crônica é uma doença de alta incidência na espécie felina, sendo responsável por altas taxas de mortalidade e morbidade. O tratamento clínico é paliativo. Atualmente as células-tronco têm sido estudadas para várias doenças degenerativas e crônicas, entre elas a doença renal. O presente estudo testou a utilização uma nova linhagem de células, progenitoras do tecido renal na terapia de gatos domésticos acometidos naturalmente com doença renal crônica, nos estágios 1, 2 e 3 da doença (creatinina $<1,6$ a 5,0 mg/dl), por meio de avaliações clínicas e laboratoriais. Os animais foram divididos em dois grupos, experimental e controle. No grupo experimental foi aplicado pela via intraperitoneal $2 \times 10^{6}$ células progenitoras renais e os animais do grupo controle receberam a aplicação de PBS. Os animais foram avaliados nos dias 0, 7 e 14 e monitorados clinicamente e por meio de exames laboratoriais, incluindo hemograma, creatinina, urinálise e o SDMA. A análise estatística foi realizada pelo teste "Scheirer Ray Hare" para dados não paramétricos $(p=0,05)$. A aplicação intraperitoneal ocorreu sem intercorrências e aparenta ser segura para utilização em gatos. Dos 4 animais do grupo experimental 3 apresentaram melhora clínica, melhora do apetite e ganho de peso, o quarto animal apresentou perda de peso inicial, mas retornou ao peso do início do estudo 14 dias após a aplicação das células. Não houve diferenças estatísticas nos parâmetros de creatinina, ureia, fósforo e densidade urinária. Os leucócitos do grupo experimental apresentaram uma redução significativa em relação ao grupo controle. O SDMA apresentou redução em 3 animal do grupo experimental e aumento nos animais do grupo controle, mas a análise não apresentou diferença estatística devido ao aumento dos valores no em um dos animais. A aplicação de células progenitoras renais no tratamento da DRC em gatos é promissora e pode ser realizada pela via intraperitoneal, sem que ocorra intercorrências.

Palavras-chave: Células-tronco. Terapia celular. DRC. Gatos. 


\begin{abstract}
NHANHARELLI, J.P. Effectiveness assessment of kidney stem cell therapy, derived from cat metanephro, in the treatment of chronic kidney disease in felines. 2018. 96f. Dissertação (Mestrado em ciências) - Faculdade de Medicina Veterinária e Zootecnia Universidade de São Paulo, 2018

Chronic kidney disease is a high incidence disease in the feline species, responsible for high rates of mortality and morbidity. The clinical treatment is palliative. Currently, stem cells have been studied for various degenerative and chronic diseases, including kidney disease. The present study tested the use of a new lineage of renal tissue progenitor cells in the therapy of naturally occurring chronic kidney disease in cats at stages 1, 2 and 3 of the disease (creatinine $<1.6$ to $5.0 \mathrm{mg} / \mathrm{dl}$ ), through clinical and laboratory evaluations. The animals were divided into two groups, experimental and control. In the experimental group $2 \times 10^{6}$ renal progenitor cells were administered intraperitoneally and the animals in the control group received PBS application. The animals were evaluated on days 0,7 and 14 and monitored clinically and through laboratory tests, including complete blood count, creatinine, urinalysis and SDMA assay. Statistical analysis was performed by the Scheirer Ray Hare test for non-parametric data $(p=0.05)$. The intraperitoneal application occurred uneventfully and appeared to be safe for use in cats. Of the 4 animals in the experimental group 3 showed clinical improvement, food intake and weight gain, the fourth animal presented initial weight loss, but returned to the weight of the study beginning 14 days after the application of the cells. There were no statistical differences in the parameters of creatinine, urea, phosphorus and urinary density. Leukocytes in the experimental group showed a significant reduction in relation to the control group. The SDMA showed reduction in 3 animals from the experimental group and increase in the animals from the control group, but the analysis did not show statistical difference due to the increase values in one of the animals. The application of renal progenitor cells in the treatment of CKD in cats is promising and can be performed intraperitoneally, without causing intercurrences.
\end{abstract}

Key words: Stem cells. Cell therapy. CKD. Cats. 


\section{LISTA DE FIGURAS}

Figura 1 - Armazenamento e preparo prévio ao transporte das células progenitoras

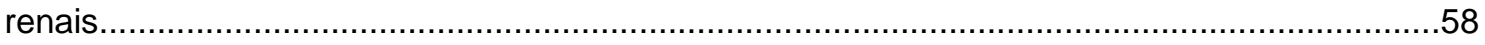

Figura 2 - Cultivo in vitro de células progenitoras renais..................................................60

Figura 3 - Armazenamento e preparo prévio ao transporte das células progenitoras

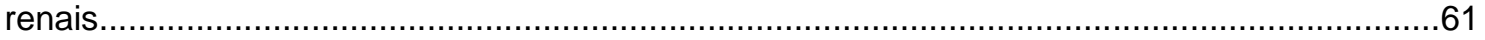

Figura 4 - $\quad$ Aplicação intraperitoneal de células progenitoras renais em gatos com doença

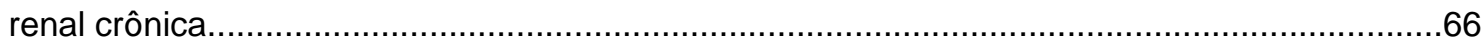

Figura 5 - $\quad$ Alterações da morfologia renal de gatos com doença renal crônica...................79 


\section{LISTA DE TABELAS}

Tabela 1 - Classificação da doença renal crônica em gatos pela "International Renal Interest Society"

Tabela 2 - Subclassificação da doença renal crônica em gatos, de acordo com a proteinúria, pela "International Renal Interest Society"

Tabela 3 - Subclassificação da DRC em gatos, de acordo com a hipertensão arterial, pela "International Renal Interest Society"

Tabela 4 - Animais portadores de doença renal crônica (DRC) selecionados no atendimento do Hospital veterinário UNISA..

Tabela 5 - Parâmetros fisiológicos dos animais avaliados antes e após aplicação de células progenitoras renais ou placebo, pela via intraperitoneal 69

Tabela 6 - Manifestações clínicas apresentadas por gatos portadores de doença renal crônica antes e após serem tratados com células progenitoras renais ou placebo 


\section{LISTA DE GRÁFICOS}

Gráfico 1 - Parâmetros fisiológicos dos animais avaliados antes e após aplicação de células progenitoras renais ou placebo, pela via intraperitoneal.

Gráfico 2 - Valores da Pressão Arterial Sistólica de gatos portadores de doença renal crônica, obtidas antes e após a aplicação de células progenitoras renais (CPRs) ou placebo.

Gráfico 3 - Avaliação do ganho de peso de gatos com doença renal crônica, antes e após a aplicação de células progenitoras renais (CPRs) ou placebo

Gráfico 4 - Valores de leucócitos totais de gatos domésticos com doença renal crônica, obtidos antes e após a aplicação de células progenitoras renais (CPRs) ou placebo

Gráfico 5 - Variações de fósforo sérico de gatos com doença renal crônica, obtidos antes e após a aplicação de células progenitoras renais (CPRs) ou placebo..

Gráfico 6 - Variações de creatinina sérica de gatos com doença renal crônica, obtidos antes e após a aplicação de células progenitoras renais (CPRs) ou placebo.

Gráfico 7 - Variações de ureia sérica de gatos com doença renal crônica, obtidos antes e após a aplicação de células progenitoras renais (CPRs) ou placebo. 76

Gráfico 8 - Variações de SDMA sérico de gatos com doença renal crônica, obtidos antes e após a aplicação de células progenitoras renais (CPRs) ou placebo.

Gráfico 9 - Variações da densidade urinária de gatos com doença renal crônica, obtidos antes e após a aplicação de células progenitoras renais (CPRs) ou placebo. 78 


\section{SUMÁRIO}

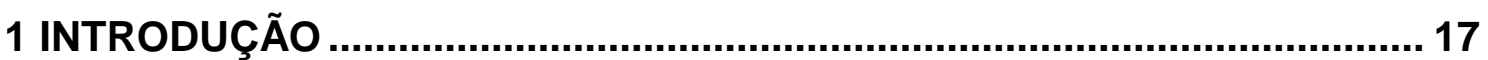

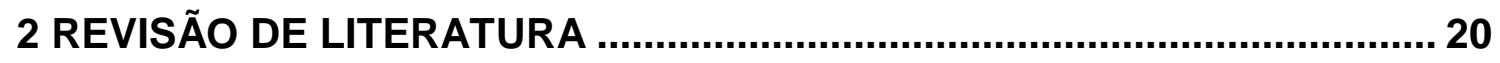

2.1 INCIDÊNCIA E PREVALÊNCIA DA DRC NA ESPÉCIE FELINA ..............20

2.2 CAUSAS RELACIONADAS AO DESENVOLVIMENTO DA DRC ............ 20

2.3. FISIOPATOLOGIA DA DRC ............................................................ 22

2.4 ALTERAÇÕES SECUNDÁRIAS A DOENÇA RENAL CRÔNICA ............ 24

2.4.1 Redução da concentração urinária ................................................. 24

2.4.2 Perda de peso e alterações gastrointestinais ................................. 24

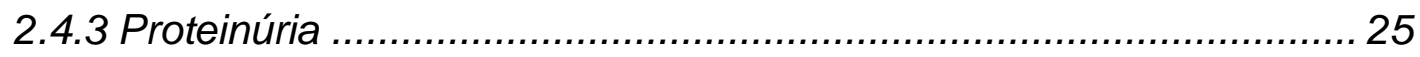

2.4.4. Hipertensão Arterial Sistêmica (HAS) .......................................... 26

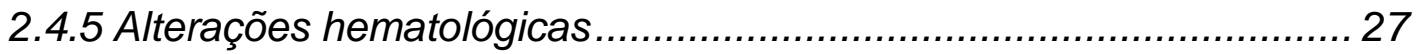

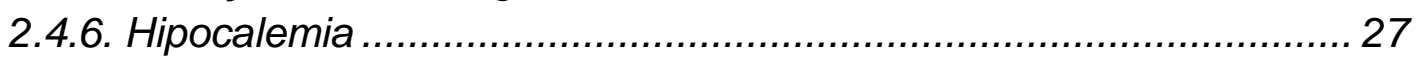

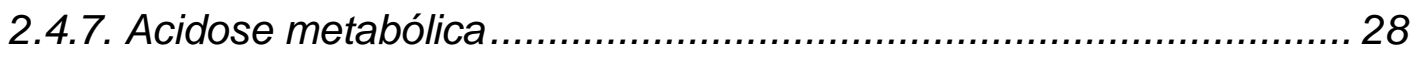

2.4.8. Hiperfosfatemia e Hiperparatireoidismo secundário renal ............... 28

2.5 MANIFESTAÇÕES CLÍNICAS DA DRC ……..................................... 30

2.6 ALTERAÇÕES LABORATORIAIS NA DOENÇA RENAL CRÔNICA....... 31

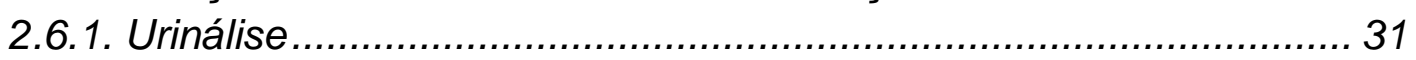

2.6.2. Alterações hematológicas........................................................ 32

2.6.3. Avaliação bioquímica da função renal .......................................... 33

2.6.4. Avaliação do metabolismo de cálcio e fósforo ................................ 34

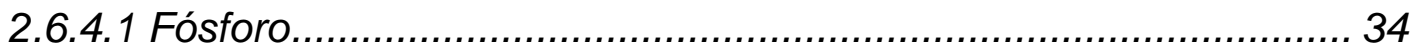

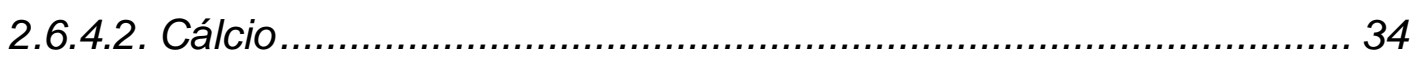

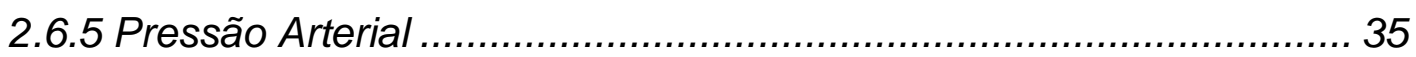

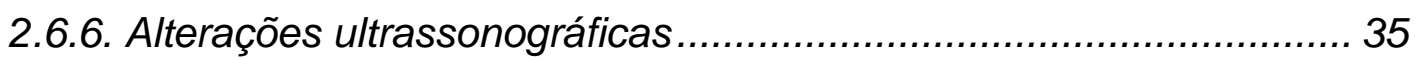

2.7. CLASSIFICAÇÃO DA DOENÇA RENAL CRÔNICA …........................... 36

2.8 TRATAMENTO DA DOENÇA RENAL CRÔNICA .................................. 38

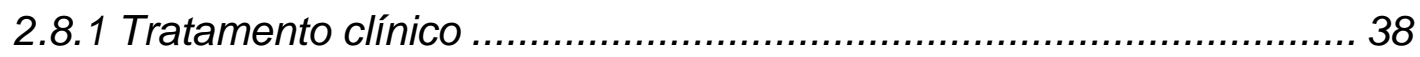

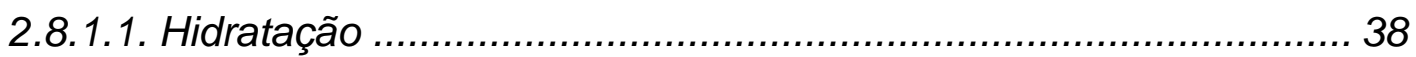

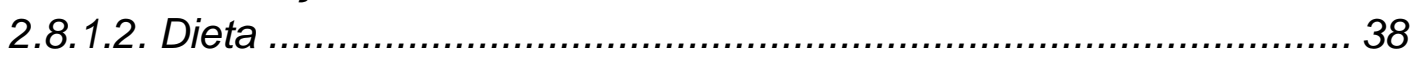

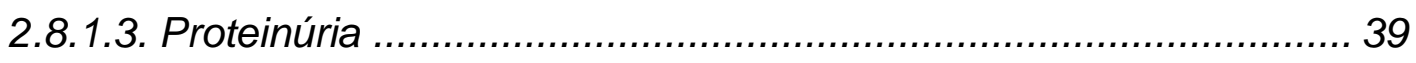

2.8.1.4. Hipertensão Arterial Sistêmica............................................... 39

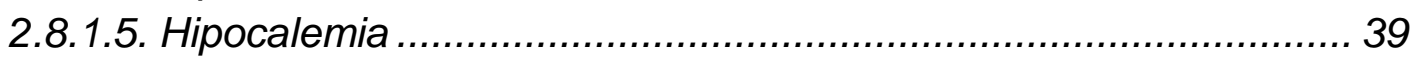

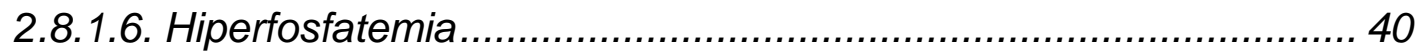

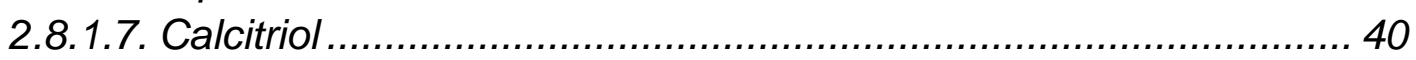

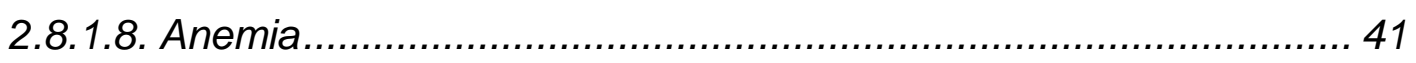

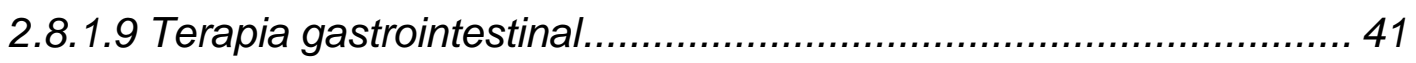

2.8.2 Terapia com células-tronco....................................................... 42

2.8.2.1 Células-tronco embrionárias .................................................... 42

2.8.2.2. Células-tronco mesenquimais.................................................. 43

2.8.2.3 Células-tronco progenitoras ......................................................... 43 
2.8.3 Ação parácrina e imunomodulatória das células-tronco. .................. 45

2.8.4 Vias para a administração das células-tronco ................................ 46

2.8.5. TERAPIA COM CÉLULAS-TRONCO NA DOENÇA RENAL ........... 47

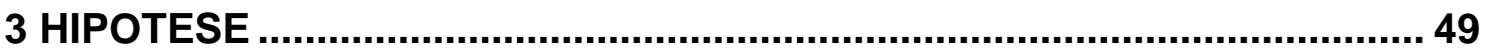

4 OBJETIVO

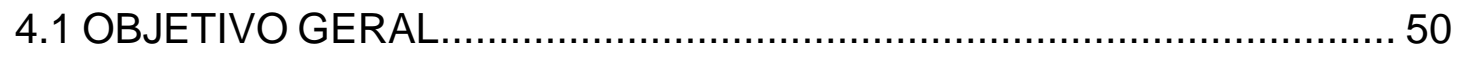

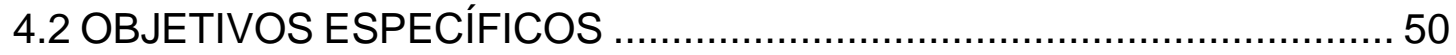

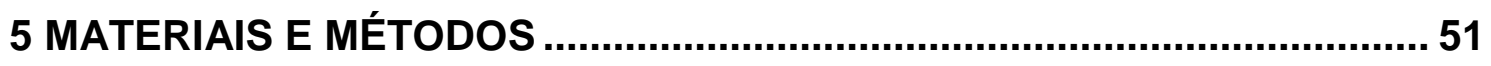

5.1. OBTENÇÃO E CULTIVO DAS CÉLULAS PROGENITORAS RENAIS ... 51

5.2 DESCRIÇÃO DOS ANIMAIS UTILIZADOS ………............................... 51

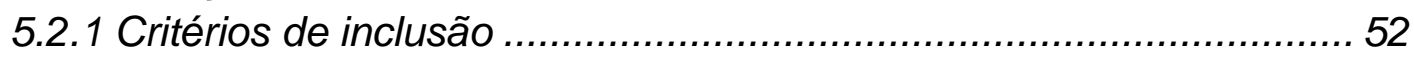

5.2.2 Critérios de exclusão .................................................................. 52

5.3. SUPORTE NUTRICIONAL E TERAPÊUTICO...................................... 52

5.4 APLICAÇÃO INTRAPERITONEAL DE CÉLULAS PROGENITORAS

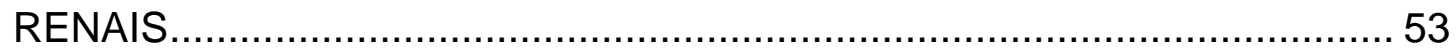

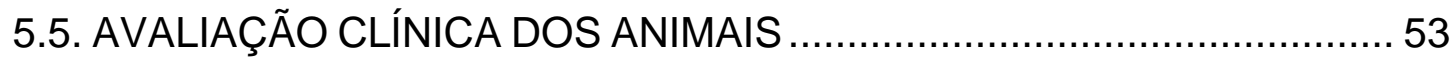

5.5.1. Avaliação clínica após a aplicação de células-tronco ou placebo.... 53

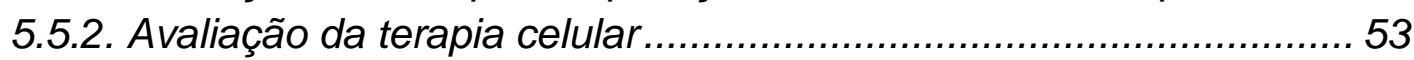

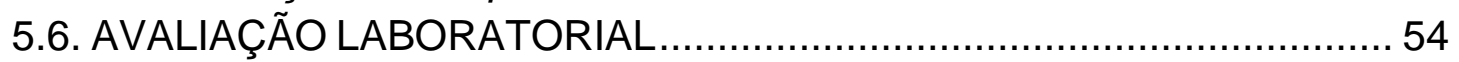

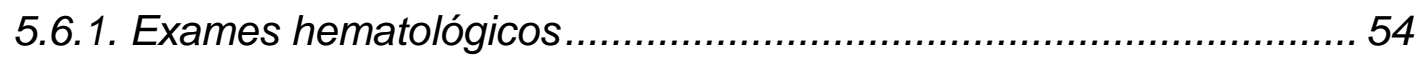

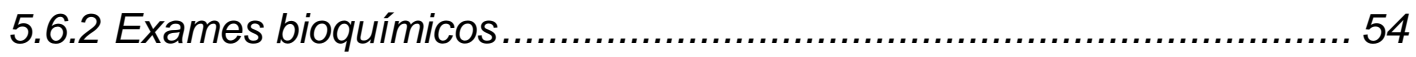

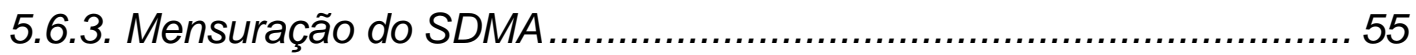

5.6.4. Sorologia para Diagnóstico de FIV E FeLV …............................... 55

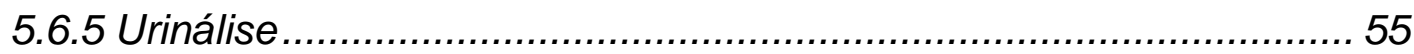

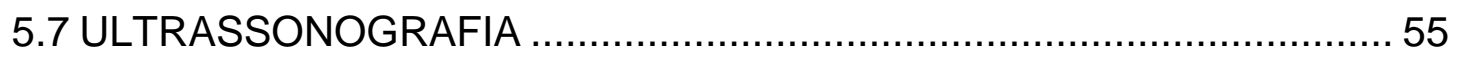

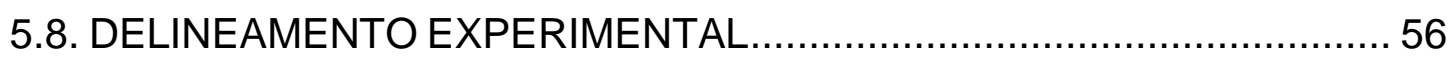

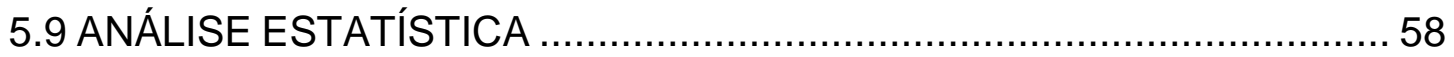

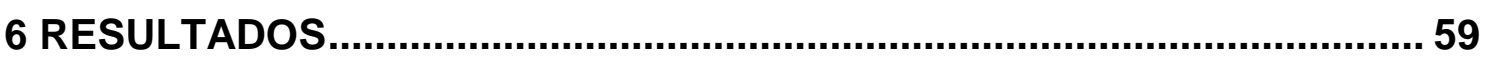

6.1 OBTENÇÃO E CULTIVO DAS CÉLULAS PROGENITORAS RENAIS .... 59

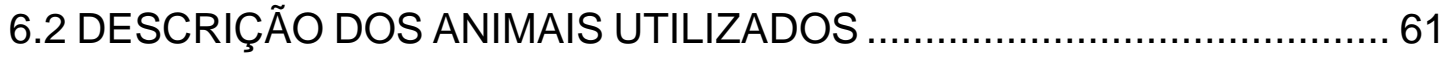

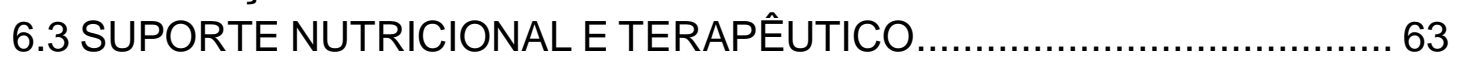

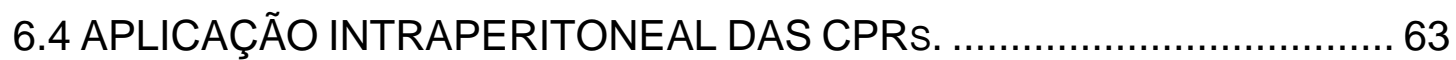

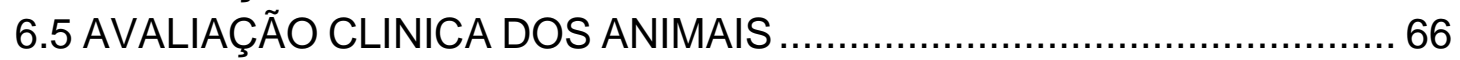

6.5.1 AVALIAÇÃO APÓS A APLICAÇÃO DE CÉLULAS-TRONCO OU PLACEBO …..........66

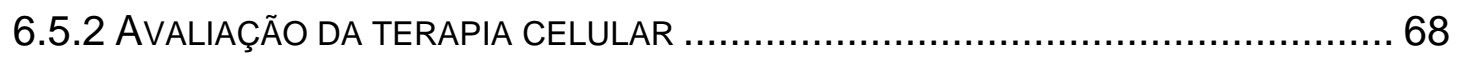

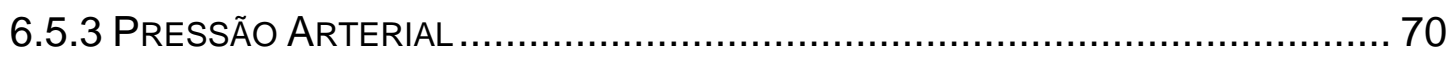

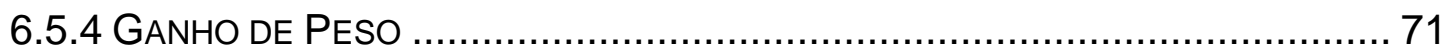

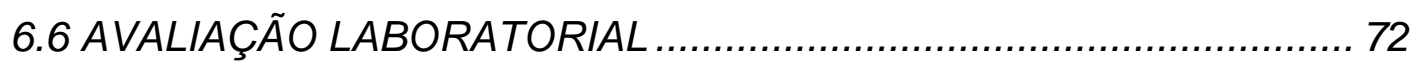

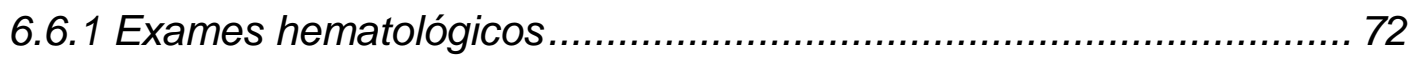

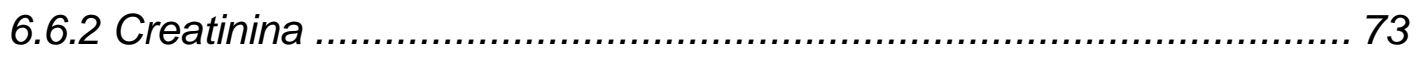

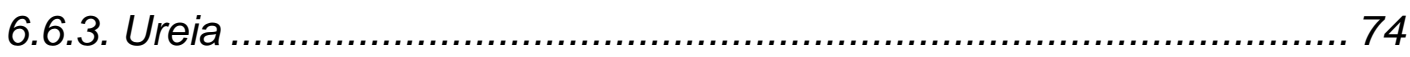




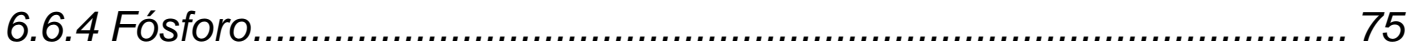

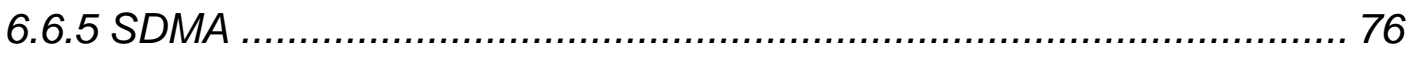

6.6.6 Urinálise ........................................................................... 77

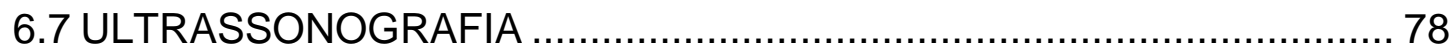

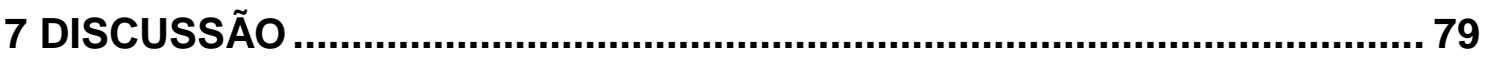

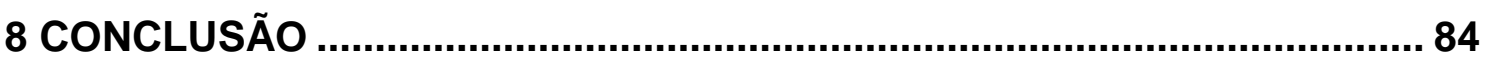

9 REFERÊNCIAS BIBLIOGRÁFICAS ....................................................... 85 


\section{INTRODUÇÃO}

A doença renal crônica (DRC) é uma doença muito frequente na espécie felina, caracterizada pela perda progressiva da capacidade funcional de um ou ambos os rins, por um período superior a 3 meses. Possui caráter progressivo e irreversível, levando, ao longo de sua evolução, a uma série de alterações metabólicas, hidroeletrolíticas e hematopoiéticas com elevado índice de mortalidade e morbidade (DIBARTOLA; RUTGERS; ZACK; TARR, 1987).

Nos felinos, a doença em sua maioria é causada por inflamação túbulointersticial, atrofia tubular e fibrose intersticial. A origem etiológica da doença muitas vezes não é claramente elucidada, mas acredita-se que seja multifatorial (CHAKRABARTI; SYME; ELLIOTT, 2012). A prevalência da doença é maior em animais idosos, machos e da raça Persa (BARTLETT; VAN BUREN; NETERER; ZHOU, 2010; LULICH; OSBORNE; O'BRIEN; POLZIN, 1992). Os animais afetados apresentam um conjunto de manifestações clínicas que variam de acordo com a gravidade e evolução da doença. Os sinais iniciais são a perda de peso progressiva, poliúria e polidipsia. Com o avanço do quadro clínico e o acúmulo de toxinas urêmicas, podem ocorrem alterações gastrointestinais, como êmese e anorexia, alterações eletrolíticas levando, anemia e alterações neurológicas (POLZIN, 2011).

O diagnóstico da DRC é realizado por meio da mensuração sérica de ureia e creatinina, as quais se elevam apenas quando $75 \%$ do rim está lesado, associada a presença de baixa densidade urinária por meio do exame de urina. Atualmente a mensuração do SDMA (Symmetric dimethylarginine) está sendo amplamente estudada para o diagnóstico precoce da DRC (HALL et al., 2014). Os níveis plasmáticos de SDMA aumentam quando há cerca de $40 \%$ de perda da capacidade renal, muitas vezes em animais assintomáticos. É utilizado também como auxiliar na classificação da doença (IRIS, 2016) por não sofrer influência da massa corpórea, como ocorre com a creatinina. A ultrassonografia abdominal e a relação proteína/creatinina urinária também são importantes para o diagnóstico da DRC, e podem apresentar alterações nos estágios iniciais da doença.

O tratamento da DRC é paliativo e visa a estabilização dos sinais clínicos e qualidade de vida por meio do restabelecimento medicamentoso do equilíbrio 
hídro-eletrolítico e ácido-base a correção das alterações metabólicas e hematológicas (BARTLETT; VAN BUREN; NETERER; ZHOU, 2010; LULICH; OSBORNE; O'BRIEN; POLZIN, 1992). A terapia com células-tronco é uma alternativa que vem sendo amplamente estudada em diversas afecções, entre elas, no tratamento da doença renal crônica. $O$ interesse principal nesse tipo de terapia é a capacidade de auto renovação e diferenciação dessas células em linhagens específicas e a sua capacidade secretora, com liberação de mediadores e fatores de crescimento tecidual que auxiliar no processo de reparação dos órgãos lesados (CHAMBERLAIN; FOX; ASHTON; MIDDLETON, 2007).

Estudos recentes utilizando modelos induzidos de DRC (secção 5/6 em ratos e camundongos) demonstraram melhora nos aspectos clínicos, laboratoriais e teciduais com redução da glomeruloesclerose e fibrose (LEE et al., 2010; SEMEDO et al., 2009; CAVAGLIERI; MARTINI; SOGAYAR; NORONHA, 2009; VILLANUEVA et al., 2013). Em felinos, os estudos realizados com células-tronco mesenquimais - provenientes de tecido adiposo, medula óssea, membrana aminiótica - também apresentaram resultados positivos quanto à melhora clínica, mas não obtiveram dados significativos quanto ao potencial regenerativo das mesmas (QUIMBY; WEBB; DOW; GIBBONS, 2011; QUIMBY; WEBB; HABENICHT; DOW, 2013; VIDANE, et al., 2016).

Acredita-se que a melhora clínica seja proveniente da ação parácrina imunomodulatória que essas células possuem, com consequente redução da inflamação do tecido renal e efeito antifibrótico, isso leva à melhora das alterações clínicas e diminuição no tempo de evolução da doença. Além de seu efeito imunomodulatório, as células-tronco mesenquimais podem ser utilizadas tanto em transplantes autólogos, quanto alogênicos, devido sua baixa expressão imunogenicidade (CAPLAN; DENNIS, 2006)

As células progenitoras são células originada de tecidos diferenciados e possuem caraterísticas intrínsecas de seus tecidos de origem. Estudos com células progenitoras são ainda mais escassos, transplantes autólogos de células provaram-se eficazes e estudos com a utilização alogênica dessas células são necessários (RANGEL et al., 2013)

Devido ao alto potencial das células-tronco na terapia da DRC e à necessidade de novos estudos na área, o presente projeto visa estabelecer um 
modelo clínico para testar a aplicação e avaliar a eficácia de células precursoras de rim - extraídas a partir de fetos de gato domésticos, no tratamento de gatos com DRC enfatizando os aspectos clínicos, laboratoriais da doença e avaliar a viabilidade do transplante celular pela via intraperitoneal na espécie felina. 


\section{REVISÃO DE LITERATURA}

\subsection{INCIDÊNCIA E PREVALÊNCIA DA DRC NA ESPÉCIE FELINA}

A doença renal crônica (DRC) é caracterizada pela perda da capacidade funcional de um ou ambos os rins e tem caráter progressivo e irreversível, por um período superior há 3 meses. A prevalência geral da DRC na população felina é de 1\% a 4\% (BARTGES, 2012; REYNOLDS; LEFEBVRE, 2013; O'NEILL; CHURCH; MCGREEVY, 2014). A doença pode acometer gatos de todas as idades, mas é mais frequente nos animais idosos. De acordo com dados da Universidade de Purdue (EUA), a média de prevalência da DRC em animais com mais de 10 anos foi de $63 \%$, sendo $31 \%$ dos gatos entre 10 e 15 anos e $32 \%$ dos animais acima de 15 anos (LULICH; OSBORNE; O'BRIEN; POLZIN, 1992). Segundo MARINO. et al. (2014), a prevalência de DRC em animais geriátricos é de $35 \%$. Apesar da alta prevalência em animais idosos, a DRC é a causa da mortalidade de cerca de $13 \%$ dos animais acima de 15 anos, sendo que muitos animais com DRC não evoluem para o estágio final da doença, e morrem de causas extra renais (O'NEILL et al., 2015).

Os gatos machos são mais acometidos que as fêmeas. As raças mais acometidas são os Persas, Siameses, Abissínios e Maine Coon (WHITE; NORRIS; BARAL; MALIK, 2006).

\subsection{CAUSAS RELACIONADAS AO DESENVOLVIMENTO DA DRC}

As causas para o desenvolvimento da DRC, podem ser de origem congênita ou adquirida. Dentre as causas congênitas as mais comuns são a doença renal policística - relacionada a uma mutação no gene PKD-1, transmitida geneticamente de forma autossômica dominante e com maior ocorrência na raça Persa, a amiloidose renal, que pode ocorrer em gatos Siameses e Abissínios e as aplasias e displasias renais, que são menos comuns na espécie felina (LYONS, 2004; WHITE; LEES, 2011).

A DRC adquirida possui causas multifatoriais, pode ser iniciada devido um processo de lesão extenso e agudo ou por diversas lesões menores que ocorrem 
ao longo da vida do animal. Entre os principais mecanismos de lesão renal relacionados com o desenvolvimento de DRC estão os processos inflamatórios e infeciosos, utilização de drogas nefrotóxicas, intoxicações, urolitíases e obstrução do fluxo renal, injúria renal aguda, hipertireoidismo, neoplasias e mais recentemente a vacinação (REYNOLDS; LEFEBVRE, 2013).

Os processos inflamatórios e infecciosos locais ou sistêmicos, causam lesões renais (nefrite intersticial, glomerulonefrite) tanto por ação direta, quanto no caso da pielonefrite, quanto por mecanismos indiretos, como vasculites e deposição de imunocomplexos na membrana glomerular. $O$ vírus da imunodeficiência felina (FIV) foi diretamente correlacionado com 0 desenvolvimento de doença renal. Em um estudo realizado por POLI; TOZON; GUIDI; PISTELLO (2012), 72 gatos foram avaliados quanto a alterações morfológicas do tecido renal, 51 experimentalmente infectados e 21 indivíduos com infecção natural. Todos os animais apresentaram aumento mesangial, glomerulonefrite lesões no tecido renal, sendo essas lesões mais evidentes nos animais naturalmente infectados. Os animais com a infecção natural também apresentavam infiltrado intersticial e amiloidose glomerular e intersticial. O vírus também foi relacionado com proteinúria moderada em $25 \%$ dos animais afetados.

Os principais agentes nefrotóxicos são os antinflamatórios não esteroidais, os antibióticos da classe dos aminoglicosídeos, sulfadiazina, agentes quimioterápicos como a doxorrubicina e o metrotrexato, ciclosporina, anfotericina $B$ e os contrastes radiológicos. As intoxicações são causadas pela ingestão de plantas tóxicas, como o lírio (Lilium sp), alimentos como uvas, uvas passas e carambola e o etilenoglicol, um anticongelante utilizado em países de clima frio (REYNOLDS; LEFEBVRE, 2013).

As urolitíases no trato urinário superior são um achado comum em felinos com DRC e pode ocorrer em $15 \%$ dos gatos acometidos. A composição mais frequente é oxalato de cálcio, o qual corresponde a $98 \%$ dos urólitos encontrados (BUCKLEY; HAWTHORNE; COLYER.; STEVENSON, 2011). KYLES et al. (2005), avaliaram 163 gatos por meio de exames de imagem e laboratoriais, 76\% dos animais que possuíam cálculos unilaterais eram azotêmicos e $56 \%$ deles possuíam redução de tamanho do rim contralateral, sugerindo que esses animais possuíam acometimento renal antes do desenvolvimento da urolitíase. 
A maior complicação relacionada às urolitíases são as obstruções do fluxo urinário, que causam hidronefrose e lesão do parênquima, podendo resultar na perda do rim afetado.

O hipertireoidismo é a doença endócrina mais comum em felinos idosos e é uma importante causa de desenvolvimento e progressão da DRC. O aumento da atividade tireoidiana leva a um aumento do fluxo sanguíneo renal e da taxa de filtração glomerular (TFG), aumento da pressão arterial, proteinúria e hipertrofia tubular, além das alterações cardíacas que podem levar a lesão renal secundária. $O$ hipertireoidismo pode também mascarar a existência e o estágio da doença renal crônica. Em animais tratados para a doença, ocorrem alterações na função renal em até 4 semanas após o tratamento (VAN HOEK; DAMINET, 2009).

O linfoma é a neoplasia primária que ocorre com maior frequência em felinos, sendo responsável por $16 \%$ dos casos de DRC (DIBARTOLA; RUTGERS; ZACK; TARR, 1987).

A vacinação contendo vírus cultivados em células renais felinas de Crandell Rees (Crandell Rees feline kidney cells - CRFK) como o herpes-vírus felino tipo 1, calicivírus e vírus da panleucopenia felina, podem mesmo após 0 processo de produção da vacina, conter proteínas CRFK que induzem a formação de anticorpos anti-CRFK e auto-anticorpos, que podem lesionar o tecido renal e causar inflamação intersticial. Não está comprovado se essa inflamação pode levar ao desenvolvimento de DRC (WHITTEMORE; HAWLEY; JENSEN; LAPPIN, 2010).

\subsection{FISIOPATOLOGIA DA DRC}

Independente da causa da lesão, a DRC leva a uma via comum, resultando na grande maioria dos casos a nefrite túbulo intersticial e fibrose do tecido renal. Em gatos, a doença glomerular primária é rara e ocorre frequentemente secundária a infecções sistêmicas ou neoplásicas (DIBARTOLA; RUTGERS; ZACK; TARR, 1987; LULICH; OSBORNE; O'BRIEN; POLZIN, 1992; ROSS et al., 2006; ICHII et al., 2011).

Após a instalação da doença, devido as lesões e perda de néfrons, ocorre um aumento compensatório da taxa de filtração glomerular (TFG) 
individual, com aumento da pressão intraglomerular dos néfrons remanescentes. O aumento do fluxo no capilar faz com que ocorra um aumento da passagem de proteínas, com maior filtração das mesmas.

O aumento de proteínas no ultrafiltrado exige um aumento da reabsorção tubular, ocasionando lesões epiteliais (BROWN; BROWN, 1995). Com a sobrecarga dos néfrons, inicia-se o estabelecimento de um processo inflamatório renal, com a infiltração de células inflamatórias polimorfonucleadas (LULICH; OSBORNE; O'BRIEN; POLZIN, 1992). A produção de citocinas prófibróticas (entre elas o TGF- $\beta 1$ ) pelas matrizes inflamatórias estimulam 0 aumento da produção de matriz extracelular pelos fibroblastos, que iniciam o processo de fibrogênese (ARATA et al., 2005). Os fibroblastos ativados, ou miofribroblastos, produzem grande quantidade de colágeno e fibronectina que se depositam no interstício, causando fibrose e disfunção renal. As células do epitélio tubular também são fontes de miofibroblastos e sofrem transformação epitélio-mesenquimal (YABUKI et al., 2010).

Outro fator envolvido na patogênese da doença renal crônica em felinos é a ativação do sistema renina-angiotensina-aldosterona (SRAA), o qual apresenta atividade elevada nesses animais (TAUGNER; BAATZ; NOBILING, 1996). A produção de angiotensina II (All) induz a vasoconstrição da arteríola eferente renal, aumentando a pressão de filtração do capilar glomerular e aumenta a produção de matriz extracelular e fibrose. A aldosterona contribui para a retenção de sódio e excreção de potássio, podendo resultar em hipocalemia e hipertensão arterial sistêmica. A hipóxia crônica e o estresse oxidativo também contribuem na patogênese da DRC em felinos (ARATA et al., 2005; LIU, 2011).

Inicialmente, o aumento da TFG dos néfrons remanescentes é suficiente para que ocorra a excreção dos produtos do metabolismo e as manifestações clínicas são brandas ou inexistentes, mas com a evolução da doença, o processo inflamatório e a hipertrofia ocasionam lesão e apoptose dos néfrons remanescentes, sendo esse processo responsável pelo caráter progressivo da doença (BROWN; BROWN, 1995). Os gatos possuem cerca de 400.000 de néfrons, para que ocorra azotemia, é necessário um comprometimento superior a $75 \%$ dos néfrons funcionais. 


\subsection{ALTERAÇÕES SECUNDÁRIAS A DOENÇA RENAL CRÔNICA}

\subsubsection{Redução da concentração urinária}

A redução da densidade urinária é uma das primeiras manifestações da DRC em gatos, principalmente pelo seu caráter de lesão tubular. A lesão tubular ocorre no início da doença, antes de ocorrer elevação da creatinina sérica (ROSS; FINCO, 1981). Os rins realizam o controle hídrico do organismo por meio da reabsorção de água pelos túbulos renais. O túbulo contorcido proximal é responsável pela absorção de cerca de $2 / 3$ da água do filtrado glomerular, por meio de um processo ativo do trocador $\mathrm{Na}^{+}-\mathrm{K}^{+}-\mathrm{ATPase}$, situado na membrana basolateral tubular, que realiza absorção dos íons de sódio e consequentemente de água. Outro importante mecanismo, principalmente para os felinos que possuem maior quantidade de néfrons justamedulares, é o sistema de contracorrente que ocorre na alça de Henle, responsável pelo aumento da osmolaridade urinária por meio da absorção passiva de água, movida pela alta concentração iônica da medula renal. Por último, no ducto coletor ocorre a ação do hormônio antidiurético, o $A D H$, responsável pelo controle central da concentração urinária (VERLANDER, 1999; ZATZ, 2012).

$\mathrm{Na}$ DRC, o aumento da TFG individual pelos néfrons, aumenta o fluxo do filtrado glomerular, reduz a absorção de sódio e água no TCP e ocasiona uma menor resposta ao hormônio antidiurético (ADH). As lesões no epitélio tubular e o aumento de solutos no filtrado reduz a absorção osmótica da água. Todos esses processos resultam na redução concentração urinária e perda de água pelo organismo (BROWN; BROWN, 1995)

\subsubsection{Perda de peso e alterações gastrointestinais}

$\mathrm{Na}$ DRC, mesmo nos estágios iniciais ocorre um aumento da taxa de metabolismo basal e, somada a redução da ingestão calórica devido a náusea e anorexia, levam os gatos com DRC a perda de peso progressiva, a qual é um fator de prognóstico negativo nesses animais (FREEMAN et al., 2015).

A regulação do apetite está alterada em animais com DRC, e acreditase que ocorra um aumento das substâncias anorexígenas (leptina, 
colecistoquinina, obestatina), associadas a redução da TFG. O acúmulo dessas substâncias é significativamente maior em animais com baixo escore corporal (QUIMBY, 2016).

As alterações gastrointestinais que ocorrem na DRC são multifatoriais e em grande parte associadas ao acúmulo de toxinas urêmicas, sendo mais frequentes nos estágios 3 e 4 da doença (POLZIN, 2011).

As toxinas urêmicas são detectadas pela zona de gatilho quimiorreceptora, localizada na área de postrema, no assoalho do 4 ventrículo, a qual causa náusea e êmese por estimulação do centro do vomito, sendo essa uma alteração bastante comum em gatos com DRC (QUIMBY, 2016)

Em humanos, a redução da TFG e o acúmulo de gastrina - um hormônio responsável pela estimulação da produção de ácido pelo estômago - é associada com hiperacidez, gastrite urêmica e ulcerações do trato gastrointestinal. Em gatos essas alterações não são frequentemente encontradas, sendo a fibrose e a mineralização gástrica os achados histopatológicos mais prevalentes nos gatos com DRC (MCLELAND et al., 2014).

Em um trabalho realizado por TOLBERT et al. (2017), foram realizadas mensurações dos níveis séricos de gastrina e monitoração do pH gástrico por 12 horas em animais saudáveis e com DRC. Nesse estudo, não houve diferenças significativas entre os grupos, sugerindo que a hiperacidez gástrica não ocorre na $\mathrm{DRC}$ em gatos.

Apesar de menos frequentes, ulcerações gastrointestinais podem ocorrer nesses animais e devem ser tratadas quando há manifestações clínicas. Nos quadros urêmicos, podem aparecer ulcerações na cavidade oral e necrose da língua (POLZIN, 2011).

\subsubsection{Proteinúria}

A proteinúria pode ser de origem glomerular, tubular ou mista e está correlacionada com o desenvolvimento de azotemia em gatos com DRC (LEES et al., 2005). O glomérulo possui uma barreira seletiva formada pelo capilar glomerular, membrana basal glomerular e pelos podócitos - células epiteliais que exibem prolongamentos ao longo do capilar. A barreira glomerular retém proteínas de alto peso molecular (acima de $60000 \mathrm{Da}$ ) e possui carga negativa que auxilia a repelir proteínas de cargas semelhantes, como a albumina (69000 
Da). Proteínas com menor peso molecular e pequenas quantidades de proteínas maiores são filtradas pelo glomérulo e em seguida reabsorvidas pelas células do epitélio tubular por meio de lisossomos que fazem endocitose e hidrólise dessas proteínas (ZATZ, 2012).

A proteinúria de alto peso molecular geralmente é de origem glomerular, que ocorrem devido a lesão na barreira seletiva e são menos comuns em gatos, ocorrendo nos estágios mais avançados da doença. Na proteinúria glomerular ocorre a perda de albumina, podendo reduzir as concentrações séricas da mesma. A proteinúria tubular ou tubulointersticial ocorre devido a falha de absorção tubular. A perda de proteínas de origem tubular é chamada de microalbuminúria e é mais comum na DRC felina, devido a etiologia da doença (WEHNER; HARTMANN; HIRSCHBERGER, 2008). A presença de uma maior quantidade de proteínas no filtrado renal também causam inflamação nos túbulos renais. $O$ aumento da reabsorção de proteínas pode levar à ruptura dos lisossomos e lesão na célula endotelial tubular (ZATZ, 2012). A proteinúria em gatos ocorre de forma moderada quando comparada a DRC em humanos, mas é significante em termos de sobrevida, visto que a proteinúria é um fator que contribui para a progressão da DRC (LEES et al., 2005; SYME, 2009).

\subsubsection{Hipertensão Arterial Sistêmica (HAS)}

A pressão arterial é controlada por diversos fatores entre eles o sistema renina-angiotensina-aldosterona (SRAA) e os metabólitos vasomoduladores como a noradrenalina e a vasopressina. As arteríolas periféricas são de grande importância para a manutenção da pressão, pequenas mudanças no calibre dos vasos, podem causar grandes mudanças na resistência vascular (KOBAYASHI et al., 1990).

Os rins possuem uma capacidade de auto-regulação da pressão interna, alterando o calibre das arteríolas renais, de forma a manter o fluxo renal e a TFG em diferentes pressões sistêmicas. Na DRC, esse mecanismo auto-regulatório pode estar alterado, levando a hipertensão glomerular e a ativação do SRAA. Os mecanismos de desenvolvimento de HAS na doença renal não são completamente elucidados (JEPSON, 2011). 


\subsubsection{Alterações hematológicas}

A produção de hemácias é regulada pela eritropoetina. A eritropoetina é um hormônio produzido pelos fibroblastos peritubulares renais que atua na medula óssea, inibindo a apoptose das células eritróides na fase de diferenciação, promovendo uma maior liberação de hemácias na corrente sanguínea. Na DRC ocorre a redução gradual da produção de eritropoetina, conforme $o$ avanço da fibrose renal, resultando em um quadro de anemia, não regenerativa (CHALHOUB; LANGSTON; EATROFF, 2011). O ferro é outro componente importante na produção das células eritróides e contribui para a maturação celular. A deficiência de ferro na DRC ocorre devido a sangramentos gastrointestinais e devido a uma redução na absorção de ferro pelo organismo, o qual é mediado pela expressão da hepicidina, um peptídeo responsável pela ativação ou inibição dos canais de ferro intestinais. A redução da hepcidina ocorre devido ao quadro inflamatório da doença. A deficiência de ferro resulta na redução do tamanho da hemácia e na capacidade de saturação da hemoglobina (GEST; LANGSTON; EATROFF, 2015).

Outros fatores que contribuem para a anemia na DRC é a redução do tempo de vida das hemácias, devido a uremia, trombocitopatia urêmica que pode agravar os sangramentos gástricos e nas fases mais avançadas, pode ocorrer mielofibrose, secundária a uremia e ação do paratormônio (CHALHOUB; LANGSTON; EATROFF, 2011).

\subsubsection{Hipocalemia}

A hipocalemia é uma alteração comum em gatos com DRC. O potássio é filtrado livremente pelo glomérulo e sua absorção ou secreção tubular variam de acordo com as necessidades orgânicas. As causas para hipocalemia na DRC são diversas, o aumento do fluxo tubular causa redução na absorção renal do potássio e consequentemente uma maior perda urinária, a ativação do SRAA, onde a aldosterona realiza a secreção de potássio em troca pelo sódio e a redução da ingestão de alimentos. Nos animais que apresentam acidose metabólica, a hipocalemia pode ocorrer devido ao deslocamento do potássio 
intracelular causado pelo alto influxo dos íons $\mathrm{H}^{+}$no interior da célula (BARTGES, 2012).

Embora seja uma alteração bastante comum, não houve associação da hipocalemia com o aumento da mortalidade (CHAKRABARTI; SYME; ELLIOT, 2012). A presença de hipocalemia é mais comum nos estágios iniciais (2 e 3) e menos comum no estágio IV, devido à redução importante da TFG e acúmulo de $\mathrm{K}^{+}$no organismo (REYNOLDS; LEFEBVRE., 2013)

\subsubsection{Acidose metabólica}

Os rins são importantes para o equilíbrio ácido básico, sendo uma das principais ferramentas no controle do $\mathrm{pH}$ sanguíneo. No túbulo contorcido, ocorre a secreção de íons $\mathrm{H}^{+}$, por meio de um transportador $\mathrm{Na}^{+}-\mathrm{H}^{+}$. Os íons $\mathrm{H}^{+}$se associam ao $\mathrm{HCO}_{3}$, presente em grande quantidade no filtrado renal, formando o ácido carbônico $\left(\mathrm{H}_{2} \mathrm{CO}_{3}\right)$, o ácido carbônico é dissociado no lúmem em $\mathrm{H}_{2} \mathrm{O}$ e $\mathrm{CO}_{2}$. $\mathrm{O} \mathrm{CO}_{2}$ é absorvido pela célula tubular e reidratado, formando novamente $\mathrm{O}$ ácido carbônico, o qual é dissociado em $\mathrm{H}^{+}{\mathrm{e} \mathrm{HCO}_{3}}^{-}$.

$\mathrm{O}$ íon $\mathrm{H}^{+}$é secretado pela célula tubular ${\mathrm{e} \mathrm{HCO}_{3}}^{-}$é reabsorvido na circulação.

$\mathrm{Na}$ DRC esse mecanismo fica comprometido. A redução na reabsorção de $\mathrm{HCO}_{3}^{-}$e na secreção de $\mathrm{H}^{+}$leva o organismo a uma sobrecarga de prótons e pode ocasionar acidose metabólica (ZATZ, 2012). Outro mecanismo que contribui para o equilíbrio ácido-base é a amoniogênese renal. Quando ocorre sobrecarga de prótons, os rins eliminam $\mathrm{NH}_{4}$ (amônia). $\mathrm{Na} \mathrm{DRC}$ a taxa de eliminação de $\mathrm{NH}_{4}$ chega a ficar de 3 a 5 vezes elevada nos néfrons remanescentes, mas é comprometida quando a massa renal fica abaixo de $20 \%$ (ELLIOTT; SYME; REUBENS; MARKWELL, 2003).

\subsubsection{Hiperfosfatemia e Hiperparatireoidismo secundário renal}

Os rins têm um importante papel no metabolismo do cálcio e fósforo. Ambos são absorvidos pelo intestino, excretados pelos rins e sofrem incorporação ou reabsorção óssea de acordo com as necessidades orgânicas. (ZATZ, 2012). O cálcio é distribuído no organismo em 3 formas distintas - ligado 
a proteínas plasmáticas, quelado com ânions (complexado) e ionizado. O cálcio ionizado (iCa) corresponde a $50 \%$ do total de cálcio no organismo e é a forma fisiologicamente ativa (GALVÃO, 2013). A homeostase do cálcio é regulada pelo paratormônio (PTH) - um hormônio sintetizado pela paratireoide o qual atua nas situações de redução do cálcio sérico, promovendo redução da excreção urinária de cálcio e ativação da vitamina $D$ - importante fator para absorção de cálcio pelo intestino e na reabsorção das reservas de cálcio ósseo, por meio do aumento da atividade dos osteoclastos (KOGIKA et al., 2006).

A vitamina $D$ tem papel fundamental na absorção de cálcio, enquanto o fósforo é reabsorvido pela forma paracelular, por meio do transporte passivo, o transporte de cálcio é feio de forma predominantemente transcelular, ativa e dependente do calcitriol, a forma ativa da vitamina $D$. A ativação da vitamina $D$ ocorre nos túbulos proximais, dependendo da necessidade metabólica. A 25hidroxivitamina $D$ (calcidiol) é sintetizada no fígado e sofre ação da enzima 1- $\alpha$ hidroxilase nos túbulos proximais, formando a 1,25 dihidroxivitamina $D$ (calcitriol), que é a forma ativa. No tecido ósseo, o calcitriol age diretamente nos osteoblastos promovendo a reabsorção óssea (KOGIKA et al., 2006).

O metabolismo do cálcio e fósforo é comprometido na $\mathrm{DRC}$ devido a dois principais mecanismos - a retenção de fósforo devido a redução da TFG e a redução do calcitriol, com consequente ativação do $\mathrm{PTH}$, levando ao hiperparatireoidismo secundário renal (HPTSR) (FOSTER, 2016).

Outro mecanismo que contribui para o HPTSR, é o fator de crescimento de fibroblastos 23 (FGF-23), hormônio regulador da excreção de fosfato ou fosfatonina, produzido em vários tecidos do organismo, mas em maior quantidade pelo tecido ósseo (FINCH, et al., 2013; GEDDES; FINCH; SYME; ELLIOTT, 2013). A redução da TFG leva a um aumento de fósforo na circulação e esse aumento estimula a ativação do FGF 23, o qual promove a fosfatúria e reduz a síntese de calcitriol. O aumento do FGF-23 pode ser notado nos estágios iniciais da doença, e em gatos é fortemente relacionado ao aumento da creatinina plasmática e aos níveis de paratormônio circulante, sendo apontado como um hormônio precursor do desenvolvimento do HPTS. (GALVÃO, 2013; GEDDES; ELLIOTT; SYME, 2015)

A hipocalcemia resultante da redução do calcitriol, se persistente, causa uma hipersecreção de PTH pelas paratireoides, levando a hiperplasia glandular, 
o qual pode evoluir para uma secreção autônoma (FOSTER, 2016). O PTH é também considerado uma toxina urêmica, responsável por alterações no sistema nervoso e mielofibrose (GEDDES; FINCH; SYME; ELLIOTT, 2013).

\subsection{MANIFESTAÇÕES CLÍNICAS DA DRC}

As manifestações clínicas da DRC variam individualmente e de acordo com a progressão da doença. Nos estágios iniciais, os principais achados são prostração, emagrecimento progressivo, hiporexia ou anorexia, poliúria, polidipsia e desidratação (DIBARTOLA; RUTGERS; ZACK; TARR, 1987). Segundo FREEMAN et al. (2015), a perda de peso inicia-se cerca de um ano antes do diagnóstico, com uma redução de cerca de $9 \%$ do peso corporal. Os animais continuam perdendo peso após o diagnóstico da doença. Alterações no apetite ocorrem em 43\% dos animais afetados (REYNOLDS; LEFEBRVE, 2013).

A HAS ocorre em $20 \%$ a $65 \%$ dos gatos com DRC e não possui manifestações clínicas específicas, sendo mais frequentemente associada quando ocorrem lesões nos órgãos alvo, como o descolamento de retina, a hipertrofia cardíaca, alterações neurológicas e comportamentais (BROWN et al., 2007; SYME, 2011).

A proteinúria ocorre com menor frequência nos gatos com DRC, 50 a 66\% dos animais não são proteinúricos. A proteinúria ocorre em cerca de $20 \%$ dos animais (SYME; MARKWELL; PFEIFFER; ELLIOTT, 2006)

A anemia é presente em 30 a $65 \%$ dos gatos com DRC e apresenta manifestações clínicas inespecíficas, como letargia, hiporexia, fraqueza e prostração. Ao exame físico achados relacionados a anemia incluem mucosas claras, hipotensão, hipotermia, redução do nível de consciência, sopro cardíaco (sopro anêmico) (CHALHOUB; LANGSTON; EATROFF, 2011).

Cerca de 20 a $30 \%$ dos gatos apresentam hipocalemia, associada a prostração, fraqueza muscular, tremores e ventroflexão cervical. A hipocalemia é menos frequente no estágio 4 da doença devido a redução da TFG (DIBARTOLA; RUTGERS; ZACK; TARR, 1987).

A acidose metabólica é uma alteração bastante frequente nos gatos com DRC, pode ocorrer em qualquer estágio da doença, mas é mais evidente nos estágios finais. Nos gatos com DRC moderada a acidose ocorre em 15\% dos 
animais, enquanto $53 \%$ dos gatos com DRC avançada apresentam essa alteração (ELLIOTT; SYME; REUBENS; MARKWELL, 2003).

A hiperfostatemia e o aumento do PTH estão presenteS em grande quantidade de animais com DRC. O HPTSR afeta de $47 \%$ a $100 \%$ dos animais, porém as manifestações clínicas são incomuns em gatos, podendo ocorrer calcificação de tecidos moles e osteoporose (DIBARTOLA; RUTGERS; ZACK; TARR, 1987; FOSTER, 2016).

Com a evolução da doença, há um acúmulo de toxinas urêmicas na circulação sanguínea, denominado de azotemia. As manifestações clínicas relacionadas a azotemia, também chamada de síndrome urêmica ou uremia, incluem as alterações gastrointestinais como anorexia, êmese, diarreia, estomatite, halitose, ulcerações gastroentéricas e alterações neurológicas como ataxia, incoordenação, obnubilação, hiperexitabilidade e convulsões (POLZIN, 2013).

\subsection{ALTERAÇÕES LABORATORIAIS NA DOENÇA RENAL CRÔNICA}

\subsubsection{Urinálise}

A urinálise é de grande importância no diagnóstico e acompanhamento da DRC, a alteração mais comumente encontrada é a diminuição da densidade urinária. Os felinos possuem uma concentração urinária que varia de 1.035 a 1.060. Na DRC a concentração urinária geralmente encontra-se abaixo de 1,035 (BARTGES, 2012; POLZIN, 2011). A análise do sedimento urinário deve ser interpretada juntamente com a DU, uma vez que em uma urina altamente diluída os sedimentos podem não ser notados. O sedimento urinário pode ter a presença de hemácias, leucócitos e bactérias, indicativos sangramentos, inflamação ou infecção do trato urinário, cristais como os de fosfato triplo, estruvita e oxalato de cálcio, que não são diagnósticos, mas podem ser indicativos de urolitíases. Cilindros, formados pela passagem de proteína pelos túbulos renais e células que podem ser de origem vesical ou do epitélio renal, que podem ser um indicativo de lesão nos rins (DIBARTOLA; RUTGERS; ZACK; TARR, 1987).

A concentração urinária alta auxilia no controle do crescimento bacteriano no trato urinário, a redução da densidade urinária na DRC pode facilitar o 
aparecimento de infecções do trato urinário (ITU). As ITUs podem ser diagnosticadas pela presença de bactérias no sedimento urinário ou pela cultura de urina, a qual pode identificar crescimento bacteriano mesmo em urinas com baixa densidade e sedimento inativo, sendo o exame de escolha para confirmação da ITU em gatos (WEESE et al., 2011).

Outro parâmetro importante é a presença de proteinúria, a qual é avaliada por meio da relação proteína/creatinina urinária (RPC). Em felinos a RPC ideal é abaixo de 0.2. A análise deve ser feita com urina coletada por cistocentese e com o sedimento inativo. Quando detectada proteinúria, é importante a exclusão de causas extra renais e coleta de amostras repetidas, com intervalos de 1 a 2 semanas, onde se detecta a persistência da mesma. (SYME, 2009).

\subsubsection{Alterações hematológicas}

A anemia normocítica, normocrômica e arregenerativa é a característica mais comum no eritrograma do animal com DRC, devido a redução da produção de eritropoetina. Nos casos de perda sanguínea crônica, deficiências de ferro e vitamina $B$, a anemia pode ser microcítica e hipocrômica, indicando alterações na fase de maturação da hemácia (CHALHOUB; LANGSTON; EATROFF, 2011).

A avaliação da anemia em felinos é realizada com base no hematócrito, o qual varia de $25 \%$ a $45 \%$ nos gatos. Valores de hematócrito abaixo de $15 \%$, são indicativos de transfusão sanguínea. A avaliação do índice de regeneração é feita por meio da contagem dos reticulócitos, que são precursores imaturos dos eritrócitos. Os gatos apresentam 2 tipos de reticulócitos, os agregados e os pontilhados. Os reticulócitos agregados, tornam-se pontilhados após um período de 12 horas e, devido a essa característica de maturação rápida, são melhores indicativos de regeneração. As plaquetas podem estar numericamente inalteradas, mas é importante considerar que a função plaquetária pode estar alterada devido a uremia. O leucograma pode estar inalterado ou ter o padrão de leucograma de estresse, com neutrofilia, linfopenia e monocitose devido ao quadro inflamatório crônico secundário a doença (WEISS; WARDROP, 2011). 


\subsubsection{Avaliação bioquímica da função renal}

O melhor teste para avaliação da função renal é a taxa de filtração glomerular, a qual pode ser mensurada por meio do plasma ou clearance renal. O clearance renal da Inulina, marcador exógeno da taxa de filtração glomerular (TFG), necessita de infusão contínua da substância e acesso a produção urinária durante 24 horas, o que dificulta a execução da técnica na rotina clínica. 0 clearance plasmático da inulina não foi estudado em gatos. O clearance da creatinina pode ser utilizado, mas necessitam de mensurações repetidas e não existe formulação comercial da creatinina. Em locais com estrutura para medicina nuclear, pode-se realizar a mensuração da TFG por meio de radioisótopos e cintilografia. A vantagem desse método é o acesso da TFG individual de cada rim. Outros métodos estão sendo estudados na espécie como a utilização do loexol, e métodos de mensuração da TFG com número reduzido de coleta de amostras, mas ainda não são utilizados na rotina clínica. A TFG em gatos é de 2 a $3 \mathrm{ml} / \mathrm{kg} / \mathrm{min}$ (FINCH; SYME; ELLIOT, 2013).

A creatinina plasmática, é correlacionada com a TFG, de fácil mensuração e amplamente utilizada na medicina veterinária, como um marcador da função renal. É produzida no organismo por meio de uma reação enzimática não reversível da fosfocreatina presente nos músculos. A creatinina não sofre interferência do catabolismo muscular, mas varia quando a massa muscular é reduzida. A excreção de creatinina é unicamente pela via renal. A desvantagem desse método é a deteç̧ão tardia da doença, pois a elevação sérica só ocorre quando cerca de $2 / 3$ do tecido renal apresenta alteração de função. $O$ valor da normalidade para a espécie felina é abaixo de 1,6 mg/dl (FINCH, 2011; IRIS, 2016).

A uréia é mensurada em conjunto com a creatinina na rotina de avaliação renal. Sua síntese é hepática, a partir da amônia derivada do catabolismo dos aminoácidos. É excretada principalmente pela urina, mas possui um grau de excreção intestinal e pode ser reabsorvida pelos túbulos renais, principalmente em casos em que ocorre redução do fluxo tubular, por isso é bastante influenciada pelas variações do volume plasmático. Os valores normais de ureia variam são de 40 a 70 mg/dl (ETTINGER, 2010). 
O aumento sérico dos níveis de ureia e creatinina são denominados azotemia. A uremia ou síndrome urêmica, é um conjunto de manifestações clínicas secundárias a azotemia (HALL et al., 2014; POLZIN, 2013).

O SDMA é uma molécula proveniente do metabolismo proteico, a qual é liberada na corrente sanguínea durante a degradação de proteínas e excretada quase que exclusivamente pela via urinária. Estudos realizados por HALL et al. (2014) e BRAFF et al. (2014), validaram a SDMA como um marcador endógeno da taxa de filtração glomerular. É utilizado tanto para diagnóstico precoce da DRC visto que seus níveis séricos aumentam com a perda de $30-40 \%$ da filtração glomerular, quanto para a monitoração da doença, visto que não se altera com níveis de massa muscular e doenças concomitantes, como o hipertireoidismo.

2.6.4. Avaliação do metabolismo de cálcio e fósforo

\subsubsection{Fósforo}

Os animais com DRC podem apresentar valores normais de fósforo no início da doença, devido a ação dos hormônios fosfatúricos. Com a redução da TFG o fósforo tende a se acumular na circulação (GEDDES; FINCH; SYME; ELLIOTT, 2013). Segundo a recomendação da IRIS (2016), os valores de fósforo toleráveis variam conforme o estágio da doença. Abaixo de $4,5 \mathrm{mg} / \mathrm{dl} \mathrm{em}$ animais estágio 2, abaixo de 5,0 mg/dl nos animais no estágio 3 e nos animais estágio 4 , abaixo de $6,0 \mathrm{mg} / \mathrm{dl}$.

\subsubsection{Cálcio}

As concentrações de cálcio sérico na DRC são variáveis e os valores podem se apresentar dentro da normalidade. Existem 3 formas de cálcio no organismo, o livre ou ionizado, o complexado e o ligado as proteínas. Os valores de cálcio total e cálcio iônico (iCa) são passíveis de mensuração. Entre eles, os valores de iCa são mais confiáveis, por não sofrer interferência dos valores de albumina (GEDDES; FINCH; SYME; ELLIOTT, 2013). Em um estudo realizado por SCHENCK; CHEW (2010), com 102 gatos com DRC, 10\% apresentavam hipocalcemia iônica. No mesmo estudo, $30 \%$ dos felinos apresentavam 
hipercalcemia iônica. Quando mensurado o cálcio total, apenas 20\% dos animais apresentavam a alteração.

\subsubsection{Pressão Arterial}

A pressão arterial sistólica (PAS) pode ser mensurada em gatos de forma não invasiva por meio de Doppler ou aparelhos oscilométricos. De acordo com a IRIS (2016), o valor ideal para a PAS em gatos é abaixo de $150 \mathrm{~mm} \mathrm{Hg}$. Para a mensuração da PAS são realizadas 5 aferições consecutivas, excluindo a primeira e a última aferição e fazendo a média entre as aferições (JEPSON, 2011).

Os valores acima da referência devem ser confirmados com 2 ou 3 aferições intervaladas para confirmação do diagnóstico. Animais muito agitados ou nervosos podem apresentar hipertensão por estresse. Valores acima de 200 $\mathrm{mm} \mathrm{Hg}$ ou com presença de lesões em órgãos alvo devem ser submetidos a terapia imediata. Os órgãos-alvo são olhos, coração, rins e cérebro. Animais hipertensos podem apresentar alterações como descolamento de retina, hipertrofia cardíaca, lesão renal e alterações neurológicas (IRIS, 2016)

\subsubsection{Alterações ultrassonográficas}

O principal exame de imagem para avaliação renal é a ultrassonografia, nela podemos observar perda da relação corticomedular, diminuição e irregularidade da parede, diminuição do tamanho renal, dilatação de pelve e alterações de ecogenicidade. Todos esses são indicativos de fibrose e inflamação renal, auxiliando no diagnóstico, muitas vezes precoce, da DRC. As alterações morfológicas podem estar presentes no estágio inicial da doença, antes do início das manifestações clínicas (DA SILVA, 2008). 


\subsection{CLASSIFICAÇÃO DA DOENÇA RENAL CRÔNICA}

A classificação mais utilizada para o estadiamento da DRC em gatos foi proposta pela IRIS (International Renal Interest Society), a qual classifica a doença em 4 estágios principais, de acordo com a creatinina sérica (Tabela 1). O estadiamento da doença é importante para o estabelecimento do tratamento adequado para cada estágio. O substadiamento da doença é feito com base na presença de proteinúria e hipertensão arterial.

Há também um grupo de risco para desenvolvimento da DRC, onde são inclusos os animais não azotêmicos e sem alterações morfofuncionais dos rins, mas que possuem um maior risco de desenvolvimento da doença, devido a alterações raciais, doenças familiares ou hereditárias, exposição a toxinas e drogas nefrotóxicas, presença de processo infeccioso sistêmico ou local que possa comprometer ou lesionar o parênquima renal ou animais idosos, que são mais predispostos ao desenvolvimento da doença.

O substadiamento pela proteinúria é realizado por meio da relação proteína creatinina urinária (RPC). São classificados como não proteinúricos os animais que apresentam valores de RPC abaixo de 0,2 , borderline proteiúrico entre 0,2 e 0,4 e proteinúrico acima de 0,4 (Tabela 2).

A classificação da hipertensão é baseada na pressão arterial sistólica (PAS) e no risco de lesão em órgãos alvo como coração, olhos, cérebro e rins. PAS abaixo de $150 \mathrm{~mm} \mathrm{Hg}$ são considerados normotensos, com baixo risco de lesão em órgãos alvo. Entre 150 e 159 mm Hg, hipertensão borderline; Entre 160 e $179 \mathrm{~mm} \mathrm{Hg}$ hipertenso com moderado risco de lesão em órgãos alvo e acima de $180 \mathrm{~mm} \mathrm{Hg}$, hipertenso com alto risco de lesão em órgãos alvo (Tabela 3).

O SDMA é um biomarcador da função renal e pode detectar redução da TFG antes das elevações da creatinina, não sendo afetado pela massa muscular do paciente. Recentemente a IRIS, 2016 considerou o SDMA como ferramenta auxiliar no estadiamento dos animais com DRC, principalmente os com baixo escore corporal.

Animais não azotêmicos, mas com aumento persistente do SDMA, acima de $14 \mu \mathrm{g} / \mathrm{dl}$ devem ser tratados como DRC estágio 1. Em animais no estágio 2, com valores de SDMA acima de $25 \mu \mathrm{g} / \mathrm{dl}$, podem ser considerados com estágio 
3 e nos animais no estágio 3 , com valores de SDMA acima $45 \mu \mathrm{g} / \mathrm{dl}$, o tratamento recomendado para o estágio 4 da doença deve ser considerado.

Tabela 1 - Classificação da doença renal crônica em gatos pela "International Renal Interest Society"

\begin{tabular}{|c|c|l|}
\hline Estágio & $\begin{array}{c}\text { Creatinina } \\
\text { (mg/dl) }\end{array}$ & \multicolumn{1}{c|}{ Comentários } \\
\hline Risco & $<1,6$ & $\begin{array}{l}\text { Animais com predisposição ao desenvolvimento de DRC, } \\
\text { animais idosos, doença infecciosa concomitante, doença } \\
\text { hereditária, exposição a toxinas nefrotóxicas, etc. }\end{array}$ \\
\hline $\mathbf{1}$ & $<1,6$ & $\begin{array}{l}\text { Não azotêmico. Alteração renal presente (redução da } \\
\text { densidade urinária, após a exclusão de causas não renais, } \\
\text { palpaçãó renal anormal ou alterações de imagem renal, } \\
\text { proteinúria renal, alterações na biopsia renal, aumento da } \\
\text { concentração de creatinina em amostras seriadas. }\end{array}$ \\
\hline $\mathbf{2}$ & $1,6-2,8$ & $\begin{array}{l}\text { Azotemia discreta. Ausência de manifestações clínicas ou } \\
\text { manifestações clínicas moderadas. }\end{array}$ \\
\hline $\mathbf{3}$ & $2,9-5,0$ & $\begin{array}{l}\text { Azotemia moderada. Várias manifestações clínicas extra } \\
\text { renais podem estar presentes. }\end{array}$ \\
\hline $\mathbf{4}$ & $>5,0$ & $\begin{array}{l}\text { Risco elevado de manifestações clínicas sistêmicas e crise } \\
\text { urêmica. }\end{array}$ \\
\hline
\end{tabular}

Fonte: IRIS (2016)

Tabela 2 - Subclassificação da doença renal crônica em gatos, de acordo com a proteinúria, pela "International Renal Interest Society"

\begin{tabular}{|c|c|}
\hline $\begin{array}{c}\text { Relação proteína/creatinina } \\
\text { urinária }\end{array}$ & Sub estágio \\
\hline$<0,2$ & Não proteinúrico \\
\hline $0,2-0,4$ & Proteinúrico borderline \\
\hline$>0,4$ & Proteinúrico \\
\hline
\end{tabular}

Fonte: IRIS (2016)

Tabela 3 - Subclassificação da DRC em gatos, de acordo com a hipertensão arterial, pela "International Renal Interest Society"

\begin{tabular}{|c|c|c|}
\hline $\begin{array}{c}\text { Pressão arterial sistólica } \\
\mathbf{m m ~ H g}\end{array}$ & $\begin{array}{c}\text { Sub estagio pela pressão } \\
\text { arterial }\end{array}$ & $\begin{array}{c}\text { Risco de lesão em orgãos } \\
\text { alvo }\end{array}$ \\
\hline$<150$ & Normotenso & Mínimo \\
\hline $150-159$ & Hipertensão borderline & Baixo \\
\hline $160-179$ & Hipertenso & Moderado \\
\hline$\geq 180$ & Hipertensão grave & Alto \\
\hline
\end{tabular}

Fonte: IRIS (2016) 


\subsection{TRATAMENTO DA DOENÇA RENAL CRÔNICA}

\subsubsection{Tratamento clínico}

\subsubsection{Hidratação}

A melhora no aporte de água deve ser iniciada nos primeiros estágios da doença. $\mathrm{O}$ aumento da disponibilidade e introdução de novas fontes de água e a alimentação úmida, são ferramentas que auxiliam a ingestão hídrica. Nos animais que não puderem ser hidratados pela via enteral ou que se mantém desidratados mesmo com uma maior ingestão de água, a hidratação pode ser realizada por meio de fluidoterapia subcutânea, com soluções eletrolíticas balanceadas (Ringer com Lactato, Normosol®). O volume a ser administrado varia de 75 a $100 \mathrm{ml} /$ dia e a frequência deve ser avaliada de forma individual. Animais debilitados ou muito desidratados devem ser hospitalizados e receber fluidoterapia intravenosa (LANGSTON, 2008; POLZIN, 2011).

\subsubsection{Dieta}

As dietas terapêuticas comerciais para DRC possuem alta densidade energética, restrição de proteínas, fósforo e sódio e suplementação com ácidos graxos, vitaminas do complexo B e potássio. A utilização da dieta adequada é associada a redução das manifestações clínicas da DRC e da hiperfosfatemia e a um maior tempo de sobrevida (ROSS, 2006). De acordo com ELLIOTT (2006) os animais com DRC que faziam o uso de dieta renal tiveram uma sobrevida de 633 dias, em comparação a 264 dias dos animais que recebiam dieta normal. A restrição proteica é um assunto bastante estudado em felinos, devido sua natureza carnívora e os animais devem ser monitorados quanto a perda de massa magra e emagrecimento (POLZIN; CHURCHILL, 2016). O início da alimentação terapêutica é recomendado em animais a partir do estágio 2 (IRIS, 2016). A troca de dieta deve ser gradual em um intervalo de 1 a 4 semanas. Nos animais que não se adaptarem com a dieta comercial, pode-se optar pela alimentação caseira balanceada (POLZIN; OSBORNE; ROSS, 2000). 


\subsubsection{Proteinúria}

O tratamento da proteinuria é recomendado para animais com relação proteína-creatinina urinária acima de 0.4. Em gatos, a utilização de benazepril demonstrou efeitos benéficos na redução da proteinúria. O bloqueador do receptor de angiotensia telmisartam apresentou eficácia na redução da proteinúria em gatos, sendo também benéfico para o controle da pressão arterial (Syme et al., 2006; IRIS, 2016).

\subsubsection{Hipertensão Arterial Sistêmica}

O controle da pressão arterial deve ser feito de forma gradual, com 0 objetivo de manter a PAS abaixo de $150 \mathrm{~mm} \mathrm{Hg}$ (IRIS, 2016). Animais com hipertensão e manifestações clínicas de lesões em órgãos alvo devem ser tratados com urgência. Em gatos, a droga de escolha para o controle da HAS é a amlodipina. Caso o controle da PAS não seja efetivo, a associação de medicações como os inibidores da enzima conversora de angiotensina (iECa) e bloqueadores do receptor de aldosterona é recomendada (JEPSON, 2011)

Em um estudo realizado LEES et al. (2012) demonstrou que os inibidores da enzima conversora de angiotensina (IECA) não apresentam resultados na regulação da PAS em gatos, quando utilizado como monoterapia. A restrição excessiva de sódio não é recomendada, por induzir a ativação precoce do SRAA (ROSS et al., 2006).

\subsubsection{Hipocalemia}

O objetivo terapêutico nos amimais com hipocalemia é que os níveis séricos de potássio se mantenham acima de $4 \mathrm{mEq} / \mathrm{dl}$. A manutenção do balanço energético positivo é essencial. Dietas terapêuticas renais para felinos são suplementadas com potássio e auxiliam na manutenção dos valores normais (REYNOLDS; LEFEBVRE., 2013).

Quando necessária a suplementação de potássio, o mesmo pode ser administrado pela via oral, na forma de gluconato de potássio ou citrato de potássio (CHAKRABARTI; SYME; ELLIOTT, 2012). Em animais com 
hipocalemia grave e hospitalizados, deve-se realizar a administração parenteral. Há também a possibilidade de administração subcutânea, a qual pode conter até $30 \mathrm{mEq} / \mathrm{L}$ (BARTGES, 2012)

\subsubsection{Hiperfosfatemia}

A restrição de fósforo é recomendada a partir do estágio 1 da doença renal crônica, por meio de troca da dieta por uma com menor teor de fósforo, como os alimentos comerciais para a animais idosos. A recomendação da troca para alimentação terapêutica é para os animais a partir do estágio 2 (IRIS, 2016). Em animais já hiperfosfatêmicos, a dieta terapêutica é instituída e o animal é reavaliado após um mês. A meta do controle de fósforo varia de acordo com o estágio da doença renal. Animais que não conseguem atingir do controle por meio da alimentação devem ter quelantes de fósforo associados ao protocolo (GEDDES; FINCH; SYME; ELLIOTT, 2013). Os quelantes mais utilizados na rotina clínica são o hidróxido de alumínio e o carbonato de cálcio. O hidróxido de alumínio, em humanos, pode causar intoxicações, levando a um quadro anêmico. A intoxicação por alumínio ainda não foi bem descrita em animais. $O$ carbonato de cálcio é uma escolha para animais que apresentam hipocalcemia concomitante, nesses o iCa necessita ser sempre monitorado (FOSTER, 2016).

\subsubsection{Calcitriol}

O calcitriol é um importante inibidor do paratormônio por meio de feedback negativo e evita a hipertrofia glandular. O calcitriol só deve ser considerado como opção terapêutica em animais com fósforo controlados, devido a possibilidade de calcificação de tecidos moles. A administração de colecalciferol (Vitamina D) pode ser administrada concomitante ao tratamento com calcitriol, principalmente em animais com hipocalcemia, mas a eficácia de sua utilização ainda não foi comprovada. Animais tratados com calcitriol os níveis de cálcio devem sempre ser monitorados, devido a possibilidade de hipercalcemia (GEDDES; FINCH; SYME; ELLIOTT, 2013). 


\subsubsection{Anemia}

Para o tratamento da anemia, inicialmente deve-se excluir as alterações sistêmicas que possam agravar o quadro anêmico como sangramentos do trato gastrointestinal, processos inflamatórios ou infecciosos concomitantes devem ser investigadas e tratadas sempre que presentes. Animais com anemia importante (abaixo de 20\%) necessitam de um acompanhamento mais frequente. Em animais com manifestações clínicas considera-se o tratamento por meio da transfusão de hemocomponentes (BARTGES, 2012).

Outro importante fator no tratamento da anemia é a suplementação de ferro. O ferro é um componente essencial na eritropoiese e pode estar reduzido na DRC. Animais com sangramentos gastrointestinais, anemia hipocrômica e sendo tratados com estimulantes da eritropoiese devem ser suplementados. A melhor formar de suplementação de ferro é pela via parenteral, visto que a absorção intestinal é menor e interfere com absorção de outros medicamentos (GEST; LANGSTON; EATROFF, 2015).

Nos casos em que as causas de base foram excluídas e há persistência do quadro anêmico, deve-se considerar deficiência de eritropoetina e instituída a terapia com estimulantes da eritropoiese. Os dois principais são a eritropoetina recombinante humana e a darboepoetina.

As complicações dos estimulantes de eriropoiese é a estimulação da produção de anticorpos anti-eritropoetina. Outra complicação associada é o agravamento do quadro hipertensivo, policitemia e aplasia da série eritrocitária. A darboepoetina é superior devido a menor indução na formação de anticorpos e pode ser administrada com um maior intervalo de tempo. Os custos são limitantes para utilização de darboepoetina. O objetivo da terapia é manter o hematócrito entre $25-35 \%$. A avaliação da medula óssea deve ser realizada em animais que não respondem a terapia (CHALHOUB; LANGSTON; EATROFF, 2011).

\subsubsection{Terapia gastrointestinal}

A terapia para as alterações gastrointestinais deve ser avaliada de forma individual. Em animais com hiporexia ou anorexia, a terapia com estimulantes de 
apetite deve ser considerada. A ciproheptadina é um estimulante de apetite de ação moderada e não apresenta comprovação científica da sua eficácia. A mirtazapina tem sido bastante estudada para o uso clínico, principalmente em felinos. Em sua ação, promove aumento do apetite e atua nos receptores de serotonina 5-TH3, auxiliando no controle da náusea (QUIMBY; LUNN, 2013).

O maropitant é a medicação de escolha para quadros eméticos devido sua inibição central do vômito. Agindo na zona de gatilho quimiorreceptora, por meio da ligação com o receptor NK-1. A ondansetrona também pode ser utilizada como terapia antiemética, mas a absorção pela via oral para gatos é de cerca de $30 \%$ e a meia vida exige administrações de até 4 vezes ao dia. A utilização subcutânea é viável, apresenta maior absorção e período de ação. Os protetores gástricos como o omeprazol e a famotidina foram muito utilizados na medicina felina, mas estudos recentes demonstraram que os gatos com DRC não apresentam hiperacidez estomacal, sendo seu uso controverso (QUIMBY; LUNN, 2013; MCLELAND et al., 2014).

Animais com sangramentos gastrointestinais podem se beneficiar do uso do sucralfato. A colocação de tubo nasoesofágico, esofágico e gastrostomia devem ser considerados em animais anoréticos que não responderam a administração de estimulantes de apetite ou para a administração de medicações em animais de difícil manejo (CHAN, 2009).

\subsubsection{Terapia com células-tronco}

\subsubsection{Células-tronco embrionárias}

As células-tronco podem ser de origem embrionária ou adultas. As células-tronco embrionárias, são células pluripotentes, isoladas das células germinativas primordiais do embrião, nas fases iniciais de seu desenvolvimento. São capazes de se diferenciar em tecidos dos três folhetos embrionários e possuem alto potencial regenerativo. A maior complicação da utilização de células embrionárias são as questões éticas da doação de embriões (FAGOONEE.; PELLICANO; SILENGO; ALTRUDA, 2011). Por terem alta capacidade de diferenciação, possuem potencial oncogênico e podem formar teratomas (MASUDA et al., 2012). 
Uma alternativa as células embrionárias são as células pluripotentes induzidas (iPS). As quais podem ser induzidas e reprogramadas a partir de células adultas, possibilitando o controle dos fatores oncogênicos. As iPS são amplamente estudadas para a sua utilização na reconstrução de órgãos in vitro e recelularização de scafolds biológicos, mas os estudos clínicos ainda são limitados (YOKOTE, 2012).

\subsubsection{Células-tronco mesenquimais}

As células-tronco mesenquimais (MSCs), são células multipotentes, capazes de se diferenciar em diferentes linhagens celulares. Podem ser isoladas de fontes como tecido adiposo, medula óssea, membranas fetais e são a linhagem celular que possuem mais estudos clínicos estabelecidos para diversos tipos de doença, agudas ou crônicas e entre elas a DRC. As células-tronco mesenquimais possuem características específicas e bem estabelecidas de aderência ao plástico, capacidade de auto-renovação, formato fibroblastóide e expressão dos marcadores CD105, CD73 e CD90, ausência dos marcadores hematopoiéticos CD34, CD45, CD14, ausência da expressão de HLA classe I e baixa expressão de HLA classe II (DOMINICl et al., 2006)

Apesar de sua capacidade de diferenciação em múltiplas linhagens celulares, estudos com a utilização in vivo das MSCs demostraram potencial para a diferenciação apenas em tecidos mesenquimais, sendo os efeitos terapêuticos benéficos demonstrados com a administração dessas células provenientes de seus efeitos parácrinos (CAPLAN; DENNIS, 2006).

$\mathrm{Em}$ gatos as células-tronco mesenquimais apresentam formato fibroblastóide, expressão CD44, CD105 e CD90. Não expressam CD18, CD4 e MHC de classe II (MARTIN et al., 2002). Essas células também exibem efeito modulatório na proliferação de linfócitos T ativado, em estudos in vitro (FIERRO et al., 2017).

\subsubsection{Células-tronco progenitoras}

As células-tronco progenitoras, são células oligopotentes, provenientes de tecidos adultos ou fetais, já diferenciados. Essas células possuem características 
intrínsecas que levam a um maior potencial de diferenciação no tecido do órgãoalvo.

O desenvolvimento renal nos mamíferos, requer a diferenciação de células progenitoras renais presentes no mesoderma intermediário em células epiteliais. Após o crescimento do broto uretérico, as células mesenquimais se aderem em suas ramificações e de diferenciam em tecido epitelial, estabelecendo a vesícula renal, precursora dos glomérulos e túbulos renais. No tecido adulto, acreditava-se que essas células progenitoras desapareciam e que o rim desenvolvido não possuía populações de células-tronco intrínsecas (COSTANTINI; KOPAN, 2010).

Células-tronco provenientes do tecido renal adulto foram encontradas na papila renal, células epiteliais tubulares, capsula de Bowman, segmento S3 dos túbulos proximais e alça de Henle. Essas células isoladas, apresentavam o marcador de células-tronco CD133 (BUSSOLATI, et al., 2005; KITAMURA et al., 2005).

RANGEL et al. (2013), isolaram células-tronco derivadas do tecido renal de ratos neonatais. Essas células foram identificadas no ramo ascendente espesso da alça de Henle e expressaram o marcador CD117 (c-kit), um receptor de tirosina quinase, presente em algumas células adultas diferenciadas como os mastócitos, células germinativas, melanócitos, células epiteliais. Também descrito como um marcador de células-tronco na medula óssea, fígado, coração, líquido amniótico e pulmões. Células c-kit+ também foram identificadas durante o desenvolvimento do mesênquima metanéfrico e o broto uretérico apresenta grande quantidade de receptores para essas células. As células c-kit+ também apresentaram características inerentes à células-tronco de autorrenovação, clonogenicidade e capacidade de diferenciação osteogênica, condrogênica, adipogênica e epitelial. A aplicação terapêutica ratos, modelo de isquemia e reperfusão demonstrou efeitos benéficos na restauração dos túbulos renais e na recuperação dos podócitos.

MARIO et al. (dados não publicados) caracterizaram células progenitoras renais, derivadas do metanéfro de fetos de gato. As células isoladas também apresentaram marcação positiva para c-kit, marcadores de células-tronco mesenquimais, capacidade de diferenciação nas linhagens adipogênica, 
osteogênica e condrogênica e auto-renovação. Estudos com a aplicação dessas células ainda não foram realizados.

\subsubsection{Ação parácrina e imunomodulatória das células-tronco.}

A ação terapêutica das células-tronco mesenquimais (CTMs) in vivo é relacionada a sua ação parácrina, com a liberação de exossomos. Os exossomos são vesículas liberadas das superfícies celulares e tem um importante papel na interação entre as células-tronco e as células residentes. Essas vesículas elas levam informações genéticas por meio de mRNA e miRNA capazes de regular a transcrição de informação genética e modulação da angiogênese (LAl; YEO; LIM, 2015). Também ocorre a liberação citocinas, como o fator de crescimento endotelial (VEGF), fator de crescimento insulina-like (IGF1 ), as quais inibem a atividade pró-fibrótica do $\operatorname{TGF} \beta$, um importante fator envolvido nos mecanismos de fibrose renal e da transição epitélio-mesenquimal que ocorre na DRC. O VEGF inibe a inflamação glomerular previne a perda de capilares peritubulares e induz a proliferação de células endoteliais (CAPLAN; DENNIS, 2006; ARATA et al., 2005)

A ação parácrina das CTMs estimula as células residentes do tecido alvo e promove a proliferação celular, por meio da ativação dos ciclos celulares de diferenciação e mitose. As CTMs apresentam diversos mecanismos imunomodulatórios, sendo relacionadas a modulação da proliferação dos linfócitos T CD4+ e CD8 ${ }^{+}$e ao aumento da expressão das células T regulatórias, as quais são responsáveis por inibir as respostas pró inflamatórias e rejeição a aloantígenos. Suprimem a formação de plasmócitos pelos linfócitos $B$ e atuam reduzindo a produção de citocinas inflamatórias pelas células dendríticas. Outra importante característica das CTMs, é o seu baixo potencial imunogênico. Apresentam baixa expressão do complexo de histocompatibilidade maior (MHC) classe I e não expressam MHC classe II (DOMINICl et al., 2006; ICHIRYU; FAIRCHILD, 2013).

O MHC é um grupo de genes responsáveis pela codificação de várias proteínas de superfície celular, conhecidas como antígenos de leucócitos, nos humanos HLA (Human Leukocyte Antigens). Possuem elevado polimorfismo, o que permite ao sistema imune reconhecer antígenos próprios e externos. É 
classificado em MHC classe I (HLA-A. HLA-B, HLA-C), encontrado na superfície celular dos linfócitos $\mathrm{T}$ citotóxicos e $\mathrm{CD} 8^{+}$, responsável por reconhecer antígenos de células e tecidos transplantados e o MHC classe II (HLA-DR, HLA-DP e HLA$D Q$ ), encontrado em células apresentadoras de antígenos - macrófagos, linfócitos B e células dendríticas (DARBÈS, 1997).

Devido a sua baixa expressão de MHC, as CTMs podem ser utilizadas em transplantes alogênicos - entre a mesma espécie, possuindo poucas complicações relacionas. O efeito imunomodulatório das CTMs também é estudado nos transplantes de órgãos, como ferramenta auxiliar na redução dos índices de rejeição pós transplante (RINGDÉN et al., 2006).

\subsubsection{Vias para a administração das células-tronco}

Diversas vias de aplicação de células-tronco foram descritas para o tratamento da doença renal, entre elas a via intravenosa, intra-arterial, subcapsular, intra-renal (SEMEDO et al., 2009; QUIMBY; WEBB; DOW; GIBBONS, 2011; QUIMBY et al., 2013; VIDANE et al., 2016). A via de intravenosa é a via mais utilizada nos tratamentos com CTMs. Por essa via, grande quantidade de células ficam presas nos capilares do pulmão, fígado e baço. Outra desvantagem dessa via, é a possibilidade de embolia, principalmente quando um maior número de células é utilizado, devido a característica de auto-adesão das células-tronco (LEE et al., 2009).

A aplicação intra-arterial melhora a distribuição das células pela circulação e diminui a retenção nos capilares e é a via que apresenta mais benefícios terapêuticos. Trabalhos com a administração renal e subcapsular também apresentaram bons resultados. A limitação dessas vias de aplicação é a necessidade de sedação do animal para as aplicações renais e em artérias de grande calibre e a limitação técnica em animais pequenos com calibre reduzido de artérias periféricas.

A via intraperitoneal é foi descrita como uma alternativa para a aplicação de células tronco. Estudos comparativos entre a via venosa e intraperitoneal demonstraram a efetividade dessa via no tratamento de diversas afecções (ELIOPOULOS et al., 2010; GAO et al., 2001; CHENG et al., 2013). Uma 
vantagem dessa via de aplicação é a possibilidade de administração de um maior volume de células, sem o risco de causar embolização (LEE et al., 2009).

A cavidade peritoneal também possui interação com o sistêma imunológico e participa da troca dinâmica de fluídos e células entre a cavidade, o sistema linfático e a circulação sanguínea. Essa troca ocorre por meio do omento, por meio de aglomerados de células, entre elas macrófagos e linfócitos, altamente vascularizadas, os vasos linfáticos mesentéricos e do peritônio e os estômatos linfáticos presentes no diafragma (STOMMEL; STRIK; VANGOOR, 2014).

As células-tronco aplicadas pela via intraperitoneal também foram encontradas em órgãos distais (WILSON et al., 2010). Algumas células formam agregados na cavidade, semelhante aos formados em cultivo tridimensionais. De acordo com BARTOSH et al. (2013), após a aplicação as células desapareceram da cavidade em uma semana, mas estimulou o recrutamento de células para o omento e a cavidade peritoneal.

\subsubsection{Terapia com células-tronco na doença renal}

Inúmeros estudos foram realizados com células tronco para o tratamento da doença renal, grande parte deles para injúria renal aguda, em modelos com roedores (MORIGI et al., 2004; SEMEDO et al., 2009; TÖGEL et al., 2007; YASUDA et al., 2012).

A maioria dos estudos demonstraram que a aplicação de células-tronco promove proteção e preserva a função renal após o insulto agudo e auxiliam na redução da lesão tubular e fibrose. Alguns desses estudos demonstraram a incorporação de um pequeno número de CTMs no parênquima renal. Ainda não está estabelecido a capacidade dessas células em se tornarem funcionais. A maioria dos estudos relacionam a efetividade do tratamento com CT devido a sua ação parácrina (MORIGl et al., 2004; KITAMURA et al., 2005)

Estudos com DRC, em modelos de indução por nefrectomia $5 / 6$, foram descritos por CAVAGLIERI, et al. (2009), SEMEDO et al. (2009), LEE et al. (2010); VILLANUEVA et al. (2011) e demonstraram um efeito benéfico nas reduções de interleucinas inflamatórias e restauração da capacidade renal. No 
entanto, resultados semelhantes não foram obtidos em modelos animais com doença renal crônica adquirida, como os gatos.

Estudos utilizando CTMs em gatos com doença renal crônica foram realizados por QUIMBY; WEBB; DOW; GIBBONS (2011) (2011, 2013, 2016), VIDANE et al. (2016).

QUIMBY; WEBB; DOW; GIBBONS (2011), realizaram um estudo piloto com a aplicação autóloga de células-tronco mesenquimais, derivadas de medula óssea (3 animais) ou tecido adiposo (3 animais), pela via subcapsular renal. Houve redução discreta da creatinina e melhora da TFG em 2 animais do grupo CTMs derivadas de tecido adiposo.

QUIMBY et al. (2013), utilizaram células-tronco alogênicas, criopreservadas de tecido adiposo em 16 gatos com DRC em diferentes estágios, em três aplicações intravenosas, com intervalo de 15 dias entre elas. Sete dos animais tratados apresentaram discreta diminuição da creatinina e quatro apresentaram melhora da TFG. Nesse estudo, os animais receberam células-tronco criopreservadas apresentaram êmese e aumento da frequência respiratória após a aplicação.

QUIMBY et al. (2016), realizaram um estudo placebo controle, com a aplicação alogênica de CTMs de medula óssea ou tecido adiposo. A aplicação de 3 doses, pela via intravenosa e com um intervalo de 14 dias. Não houveram diferenças estatísticas entre os grupos.

VIDANE et al. (2016), utilizaram CTMs derivadas do âminion fetal em 9 gatos. A aplicação foi realizada pela via intravenosa, com 21 dias de diferença. Uma discreta redução de creatinina foi notada.

Não existem estudos utilizando células progenitoras renais na espécie felina. 


\section{HIPOTESE}

As células progenitoras renais, derivadas de metanéfro de gato, possuem características intrínsecas de seu tecido de origem e apresentam efeitos benéficos na terapia da doença renal crônica em felinos domésticos. A aplicação das células-tronco renais pela via intraperitoneal demonstra potencial terapêutico, e constitui uma via segura para terapia celular em gatos. 


\section{OBJETIVO}

\subsection{OBJETIVO GERAL}

Avaliar a eficácia do transplante alogênico intraperitoneal de célulastronco renais em gatos portadores de doença renal crônica e testar seus efeitos terapêuticos por meio da avaliação clínica e laboratorial dos animais afetados.

\subsection{OBJETIVOS ESPECÍFICOS}

- Estabelecer um método de aplicação intraperitoneal de células-tronco na espécie felina;

- Avaliar a segurança e a presença de efeitos adversos à aplicação de célulastronco por essa via;

- Avaliar a presença de alterações hematológicas após a aplicação alogênica das células progenitoras renais;

- Avaliar o efeito terapêutico das células progenitoras renais nos gatos portadores de DRC;

- Monitorar a progressão do quadro clínico desses animais por meio da avaliação clínica, hematológica, bioquímica e urinária. 


\section{MATERIAIS E MÉTODOS}

\subsection{OBTENÇÃO E CULTIVO DAS CÉLULAS PROGENITORAS RENAIS}

As células progenitoras renais (CPRs) foram obtidas do metanefro de feto de gato doméstico de 60 dias. Após a obtenção dos úteros gravídicos, os fetos foram expostos da placenta e os rins foram retirados e levados ao cultivo primário. Em seguida, realizou-se a lavagem dos mesmos em solução de PBS (Phosphate Buffered Saline) e amicacina 0,5\%, durante 15 minutos.

Após esse período os rins foram transferidos para o fluxo de cultivo primário e as células extraídas por meio de maceração e mantidas no meio de cultivo DMEN F12 (Gibco by Life Technologies, NY, USA \#10565018), enriquecido com aminoácido $1 \%$, amicacina $0,5 \%$ e soro fetal bovino $10 \%$ até que atingissem a confluência de $80 \%$, em cerca de 4 a 5 dias. Após esse período, as células foram tripsinisadas e recultivadas até a passagem 3 . Antes de serem aplicadas, as células foram tripsinisadas e ressuspendidas em PBS (solução fisiológica fosfatada) e centrifugadas, três vezes seguidas, a $1200 \mathrm{rpm}$, durante 5 minutos, para a retirada do meio de cultivo.

Uma amostra era separada após a centrifugação, para a contagem pelo método de Azul de Trypan (1:1). As células foram contadas na câmara de Neubauer e utilizadas na concentração de $2 \times 10^{6}$ células $/ \mathrm{ml}$, as quais eram ressuspendidas em $1 \mathrm{ml}$ de PBS e armazenadas em um criotubo para 0 transporte.

As células que foram utilizadas nesse estudo são células progenitoras renais. A caracterização dessas células e o estabelecimento de cultura foram realizadas em um estudo paralelo, ainda não publicado (CEUA № 9798110215).

\subsection{DESCRIÇÃO DOS ANIMAIS UTILIZADOS}

Foram utilizados gatos machos e fêmeas de 5 a 10 anos, provenientes de proprietários particulares, atendidos no Hospital Veterinário da Universidade de Santo Amaro (UNISA) no período de outubro de 2017 a maio de 2018. 


\subsubsection{Critérios de inclusão}

Todos os animais possuíam doença renal crônica, nos estágios 1 a 3 (creatinina $<1,6$ a 5,0 mg/dL) pela classificação "International Renal Interest Society" (IRIS, 2016), com quadro clínico estável, ausência de urolitíases e/ou obstruções no trato urinário superior ou inferior, ausência de doenças concomitantes e com sorologia negativa para FIV (Feline Immunodeficiency Vírus) e FeLV (Feline Lekemia Vírus).

Os animais foram inclusos no estudo somente após a ciência do tutor e assinatura do termo de consentimento livre esclarecido (TCLE).

\subsubsection{Critérios de exclusão}

Foram excluídos os animais com doença renal estágio IV, presença de doenças concomitantes previamente diagnosticadas, evidências clínicas e laboratoriais de lesão renal aguda, processos obstrutivos das vias urinárias, portadores sintomáticos ou assintomáticos de FIV e FeLV. Não adesão do tutor do animal ao tratamento ou animais de difícil manejo e contenção.

\subsection{SUPORTE NUTRICIONAL E TERAPÊUTICO}

Não foram realizadas troca de alimentação durante o período do estudo. Todos os animais alimentavam-se com dieta seca comercial e com alimento úmido ocasional.

Os animais receberam suporte medicamentoso quando necessário, porém alterações terapêuticas foram realizadas antes do início do experimento. Dentre as medicações utilizadas como suporte estão os protetores gástricos omeprazol (União Química S.A., Brasil) 0,5mg/kg/q12h ou famotidina (EMS S.A., Brasil) $0,5 \mathrm{mg} / \mathrm{kg} / \mathrm{q} 12 \mathrm{~h}$, antieméticos - ondansetrona $1 \mathrm{mg} / \mathrm{kg} / \mathrm{q} 8 \mathrm{~h}$ famotidina (EMS S.A., Brasil) ou maropitant $1 \mathrm{mg} / \mathrm{kg} / \mathrm{q} 24 \mathrm{~h}$ (PFIZER LTDA, UK) quelantes de fósforo - hidróxido de alumínio 90mg/kg/dia (EMS S.A., Brasil) e estimulantes de apetite mirtazapina 1,88 mg/animal/48h (NOVARTIS LTDA, Brasil).

A necessidade e frequência de reposição hídrica por meio de fluidoterapia subcutânea com ringer com lactato foi avaliada individualmente. 


\subsection{APLICAÇÃO INTRAPERITONEAL DE CÉLULAS PROGENITORAS RENAIS}

A aplicação das células-tronco renais ou placebo foi realizada pela via intraperitoneal. Os animais foram contidos de forma manual, em decúbito dorsal. $\mathrm{O}$ acesso a cavidade abdominal foi guiado por ultrassonografia e para a antissepsia da região foi utilizada clorexidina alcoólica. A punção foi realizada na linha alba, dois centímetros abaixo da cicatriz umbilical, com cateter 24G.

\subsection{AVALIAÇÃO CLÍNICA DOS ANIMAIS}

5.5.1. Avaliação clínica após a aplicação de células-tronco ou placebo

Após a aplicação intraperitoneal, os animais foram monitorados quanto os parâmetros clínicos de frequência cardíaca, frequência respiratória, pressão arterial sistólica e temperatura. Também foi avaliado dor ou desconforto à palpação abdominal. A avaliação ocorreu imediatamente antes da aplicação e nos 10 e 20 minutos seguintes.

\subsubsection{Avaliação da terapia celular}

A avaliação clínica foi realizada por um médico veterinário - atuante na área de clínica médica de pequenos animais - com a presença do tutor do animal. Os animais foram avaliados antes da aplicação das células (D0), sete (D7) e quatorze (D14) após.

Os tutores foram questionados sobre o comportamento e atividade do animal em casa, ingestão de água, apetite, micção e evacuação, por meio de um questionário clínico (Anexo A), o qual foi utilizado em todas as avaliações.

Ao exame físico, os animais foram avaliados quanto ao estado de consciência e resposta ao ambiente no momento da avaliação, peso, escore de condição corporal (ECC), hidratação, coloração de mucosas, frequência cardíaca e respiratória e pressão arterial sistólica. 
A pressão arterial sistólica foi mensurada com Doppler, no membro torácico esquerdo. A escolha do manguito foi definida por meio da mensuração da circunferência do membro do animal. Foram realizadas 5 mensurações consecutivas, exclusão dos valores da primeira e da última mensuração, somado os valores das mensurações restantes e dividido por 3. O valor final foi corrigido para que os valores terminassem em 5 ou 0 .

\subsection{AVALIAÇÃO LABORATORIAL}

A análise do hemograma, mensuração sérica de ureia, creatinina, fósforo e urinálise foram realizadas no Laboratório de Análises clínicas do Hospital Veterinário da Universidade de Santo Amaro (Hovet UNISA) e as amostras de SDMA em um laboratório conveniado IDEXX (IDEXX Brasil Laboratórios LTDA).

\subsubsection{Exames hematológicos}

Para o hemograma, as amostras sanguíneas coletadas por punção venosa, após jejum alimentar de seis (6) horas e armazenadas em tubos coletores contendo EDTA K2 sob refrigeração de $4^{\circ} \mathrm{C}$. As amostras foram processadas no mesmo dia em um aparelho hematológico automático (BC 2800 Vet, Mindray, China) para a mensuração de leucócitos totais, eritrócitos, hemoglobina, hematócrito e plaquetas. A contagem diferencial dos leucócitos foi realizada por um veterinário especializado em patologia clínica, por microscopia óptica dos esfregaços sanguíneos, corados pelo método panótico

\subsubsection{Exames bioquímicos}

Para as mensurações séricas de ureia, creatinina e fósforo, as amostras sanguíneas foram coletadas por punção venosa e armazenadas em tubo seco $\mathrm{cm}$ ativador de coágulo sob refrigeração de $4^{\circ} \mathrm{C}$. O processamento foi realizado no mesmo dia da coleta, por bioquímica colorimétrica do soro sanguíneo, utilizando kits comerciais (Labtest, Brasil). 


\subsubsection{Mensuração do SDMA}

A dosagem do SDMA (Symmetric dimethylarginine) foi realizada por meio do soro sanguíneo, obtido por punção venosa e armazenado em tubo seco com ativador de coágulo. As amostras foram centrifugadas no mesmo dia da coleta e congeladas a $-20^{\circ} \mathrm{C}$ para análise posterior. As amostras foram analisadas no aparelho Catalyst One Veterinary Chemistry Analyzer (IDEXX laboratórios LTDA, US).

\subsubsection{Sorologia para Diagnóstico de FIV E FeLV}

O soro sanguíneo, obtido por punção venosa e armazenado em tubo seco com ativador de coágulo. As amostras foram centrifugadas no mesmo dia da coleta e congeladas a $-20^{\circ} \mathrm{C}$ para análise posterior. O diagnóstico de FIV e FeLV foi realizado utilizando o kit comercial SNAP Combo Plus (IDEXX Laboratórios LTDA, Brasil).

\subsubsection{Urinálise}

A urina foi coletada por cistocentese guiada por ultrassom e armazenada em tubo estéril por no máximo 8 horas. A amostra foi analisada quando a coloração, turbidez e densidade (por meio de refratômetro). A análise química foi realizada por meio de fita reagente colorimétrica comercial (Labtest, Brasil) e a avaliação do sedimento foi realizada por microscopia óptica do sobrenadante, após a centrifugação da amostra. A mensuração de proteína e de creatinina urinária foi realizada nas amostras com sedimento inativo, por bioquímica colorimétrica, utilizando kits comerciais (Labtest, Brasil). A relação proteína/creatinina urinária (RPC) foi obtida pela razão entre os dois valores.

\subsection{ULTRASSONOGRAFIA}

O exame ultrassonográfico foi realizado com jejum alimentar de seis (6) horas e água ad libitum. Foi realizado a tricotomia da região ventral do abdômem. O exame foi realizado com um transdutor $7,5 \mathrm{MHz}$. Os rins foram avaliados 
quanto a topografia, tamanho, arquitertura interna, ecotextura, ecogenicidade e presença de urolitíases.

\subsection{DELINEAMENTO EXPERIMENTAL}

Os animais foram selecionados por meio de avalições prévias, realizadas no atendimento clínico do Hovet UNISA, as quais apresentavam alterações sugestivas de DRC. Os tutores eram contatados e caso concordassem com a adesão ao experimento, os animais eram separados nos grupos $E$ (experimental) e grupo C (controle). A inclusão nos grupos foi realizada de forma aleatória, conforme a adesão dos tutores.

A avaliação clínica foi realizada por um médico veterinário do Hovet UNISA, especializado em medicina felina. O veterinário avaliador e os tutores não sabiam o grupo em que se encontravam os animais. Os tutores dos animais do grupo placebo foram informados após o término do estudo. Nos animais do grupo $E$ foram aplicadas $2 \times 10^{6}$ células, ressuspendidas em $3 \mathrm{ml}$ de solução fisiológica fosfatada (PBS) e nos animais do grupo $\mathrm{C}$ foi aplicado $3 \mathrm{ml}$ de PBS. O delineamento experimental está descrito no esquema abaixo (Figura 1): 
Figura 1 - Protocolo experimental utilizado para a aplicação intraperitoneal de células progenitoras renais e monitoração dos animais.

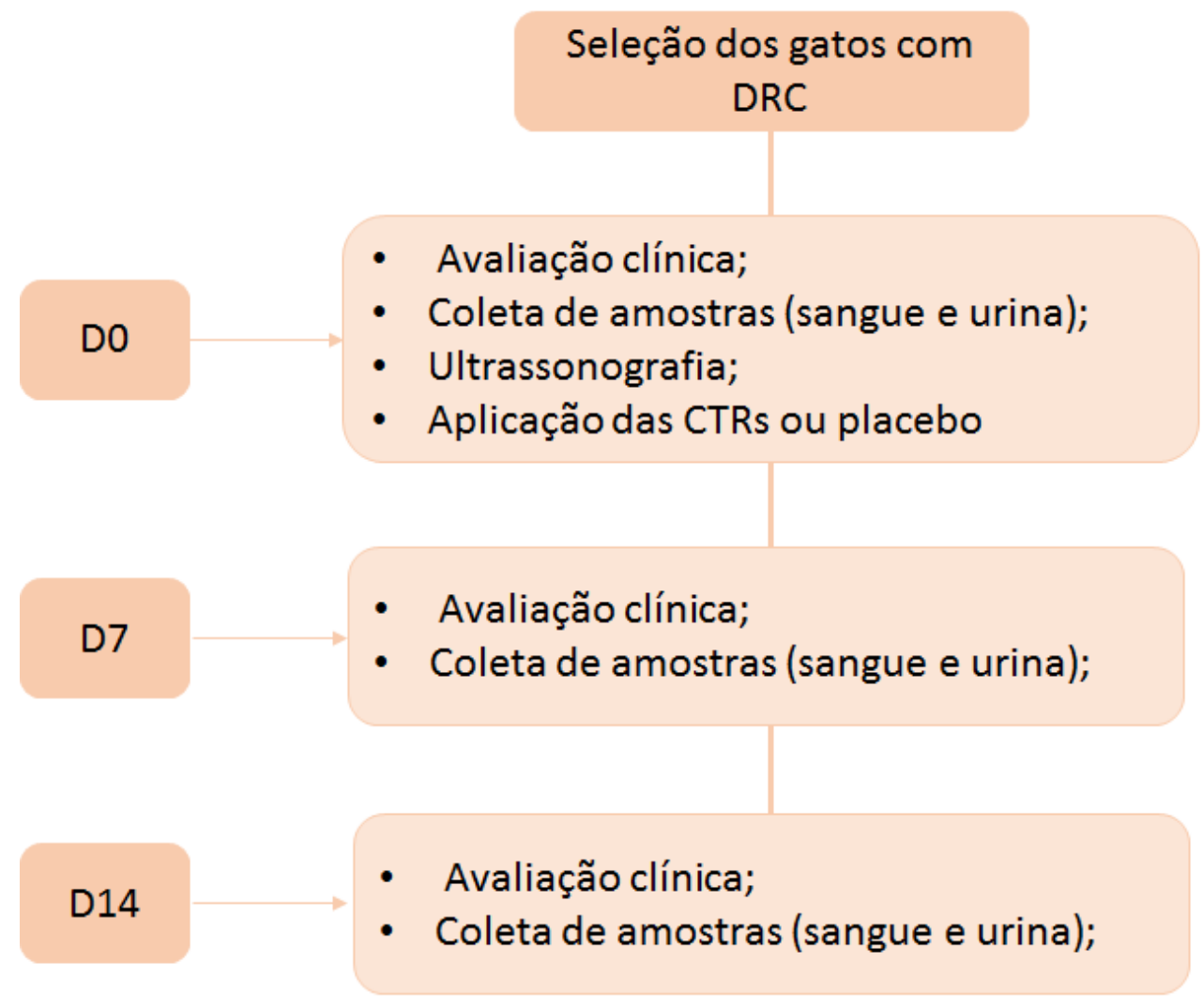

Fonte: NHANHARELLI, J. P. (2018) 


\subsection{ANÁLISE ESTATÍSTICA}

As variáveis creatinina, SDMA, densidade urinária, fósforo, leucócitos, peso e pressão arterial foram avaliados tiveram seu comportamento avaliados segundo o grupo e tempo de avaliação. Os dados foram submetidos à estatística inferencial segundo o teste de "Scheirer Ray Hare", alternativa não paramétrica ao ANOVA 2 Fatores. Adotou-se como nível de significância o valor de 5\%. 


\section{RESULTADOS}

\subsection{OBTENÇÃO E CULTIVO DAS CÉLULAS PROGENITORAS RENAIS}

As células obtidas do metanefro dos fetos de gato foram cultivadas no meio DMEN F12 (Gibco by Life Technologies, NY, USA \#10565018), suplementado com $1 \%$ de aminoácidos, $0,5 \%$ de amicacina e $10 \%$ de soro feral bovino. As células foram mantidas em estufa, a $37^{\circ} \mathrm{C}$ até atingirem a confluência de $80 \%$, o que ocorreu em torno de 96 horas após o processamento inicial. As células explantadas foram tripsinisadas e transferidas para 2 placas de cultivo de $60 \mathrm{~mm}$ (Gibco by Life Technologies, NY, USA), sendo esse processo repetido até a passagem 3 (P3) (Figura 2).

Figura 2 - Cultivo in vitro de células progenitoras renais
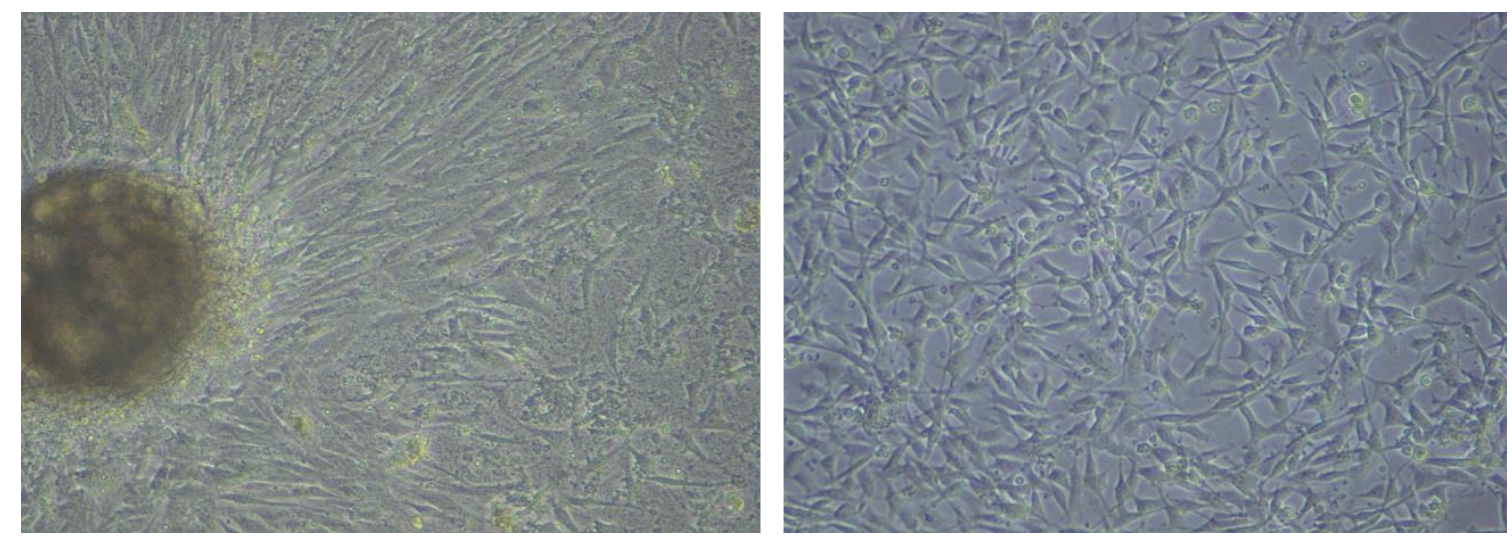

Fonte: NHANHARELLI, J.P. (2018)

Legenda: A - Migração de células a partir do explante do tecido renal; B - Linhagem celular do tipo mesenquimal renal aderida na superfície de cultivo, apresentando morfologia fibroblastóide 20ul (20x).

Após esse período, as células selecionadas para a aplicação foram tripsinisadas e ressuspendidas em PBS (solução fisiológica fosfatada), sendo centrifugadas a $1200 \mathrm{rpm}$, durante 5 minutos, três vezes seguidas, para a retirada do meio de cultivo. Uma amostra das células era separada após a centrifugação e contadas pelo método de Azul de Trypan (1:1). As células foram contadas na câmara de Neubauer e apresentaram alto nível de viabilidade. Após a contagem as células foram ressuspendidas em PBS e utilizadas na concentração de $2 \times 10^{6}$ células $/ \mathrm{ml}$. As células excedentes ao valor estipulado foram descartadas por meio de diluição. 
A amostra de células era então identificada e armazenada em criotubo, para o transporte, o qual era realizado sob refrigeração (Figura 3). O intervalo máximo entre o processamento, transporte e utilização foi de 1 hora.

Figura 3 - Armazenamento e preparo prévio ao transporte das células progenitoras renais

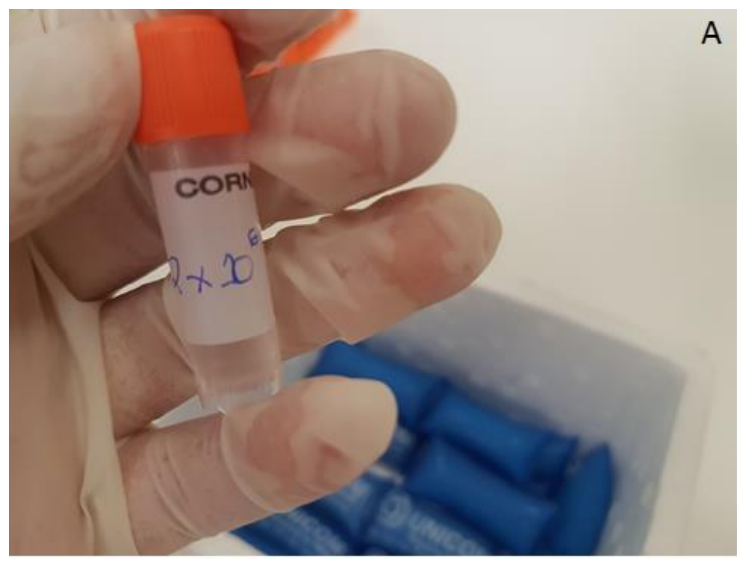

A

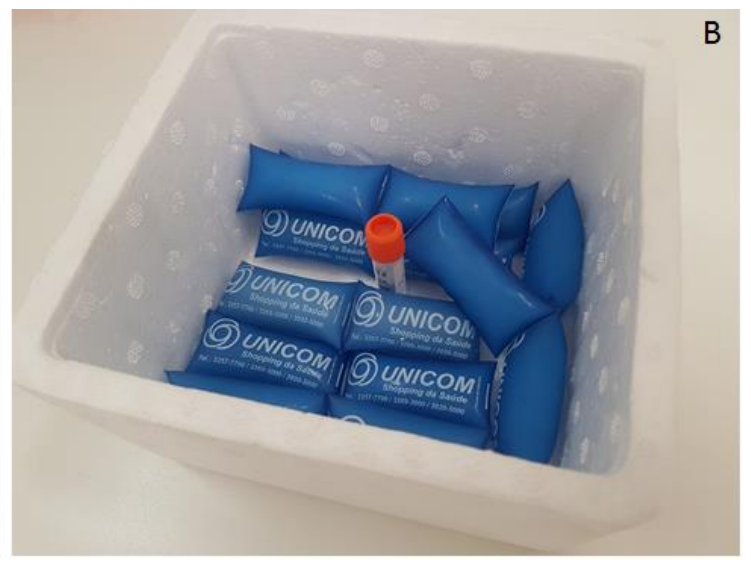

Fonte: NHANHARELLI, J. P. (2018)

Legenda: A - células progenitoras renais, após a contagem de $2 \times 10^{6}$ e armazenamento em criotubo; B - Acondicionamento da amostra de células previamente ao transporte. 


\subsection{DESCRIÇÃO DOS ANIMAIS UTILIZADOS}

Os animais que atendiam aos critérios de inclusão foram descritos, de acordo com o grupo e o estágio da doença na tabela abaixo (Tabela 4).

Tabela 4 - Animais portadores de doença renal crônica (DRC) selecionados no atendimento do Hospital veterinário UNISA.

\begin{tabular}{|c|c|c|c|c|c|c|c|}
\hline \multirow{2}{*}{$\underset{I}{\text { Anima }}$} & \multirow[t]{2}{*}{ Grupo } & \multirow[t]{2}{*}{ Descrição } & \multicolumn{4}{|c|}{ Critérios de inclusão } & \multirow{2}{*}{$\begin{array}{l}\text { Estági } \\
\text { o DRC } \\
\text { (IRIS) }\end{array}$} \\
\hline & & & Creatinina & DU & $\begin{array}{c}\text { Alteração } \\
\text { morfológic } \\
\text { a }\end{array}$ & FIV/FeLV & \\
\hline 1 & $E$ & $\begin{array}{c}8 \text { anos FC } \\
\text { SRD }\end{array}$ & $2,25 \mathrm{mg} / \mathrm{dl}$ & 1,016 & Sim & Negativo & 2 \\
\hline 2 & $E$ & $\begin{array}{c}9 \text { anos FC } \\
\text { SRD }\end{array}$ & $2,89 \mathrm{mg} / \mathrm{dl}$ & 1,021 & Sim & Negativo & 3 \\
\hline 3 & $E$ & $\begin{array}{c}6 \text { anos FC } \\
\text { SRD }\end{array}$ & $1,5 \mathrm{mg} / \mathrm{dl}$ & 1,050 & Sim & Negativo & 1 \\
\hline 4 & $E$ & $\begin{array}{c}7 \text { anos MC } \\
\text { SRD }\end{array}$ & $1,70 \mathrm{mg} / \mathrm{dl}$ & 1,017 & Sim & Negativo & 1 \\
\hline 5 & $E$ & $\begin{array}{c}10 \text { anos MC } \\
\text { SRD }\end{array}$ & $2,70 \mathrm{mg} / \mathrm{dl}$ & 1,015 & Sim & Negativo & 2 \\
\hline 1 & $\mathrm{C}$ & $\begin{array}{c}7 \text { anos FC } \\
\text { SRD }\end{array}$ & $1,6 \mathrm{mg} / \mathrm{dl}$ & 1,050 & Sim & Negativo & 1 \\
\hline 2 & $\mathrm{C}$ & $\begin{array}{c}8 \text { anos FC } \\
\text { SRD }\end{array}$ & $4,1 \mathrm{mg} / \mathrm{dl}$ & 1,019 & Sim & Negativo & 3 \\
\hline 3 & C & $\begin{array}{c}9 \text { anos MC } \\
\text { SRD }\end{array}$ & $2,57 \mathrm{mg} / \mathrm{dl}$ & 1,021 & Sim & Negativo & 2 \\
\hline 4 & C & $\begin{array}{c}7 \text { anos FC } \\
\text { SRD }\end{array}$ & $2,8 \mathrm{mg} / \mathrm{dl}$ & 1,022 & Sim & Negativo & 3 \\
\hline
\end{tabular}

Fonte: NHANHARELLI, J. P. (2018)

Legenda: FC - fêmea castrada; MC - macho castrado; SRD - sem raça definida; Grupo E experimental (aplicação de células-troncos renais 2x106); Grupo C - controle.

\section{Grupo Experimental}

Animal 1E: Mel, SRD, fêmea, 8 anos, pelagem preta, castrada. Histórico de emagrecimento progressivo, poliúria e polidipsia. Apresentou alterações morfológicas renais na ultrassonografia, creatinina 2,3 $\mathrm{mg} / \mathrm{dl}$ (primeiro atendimento) e baixa densidade urinária, sendo classificada como DRC estágio 2.

Animal 2E: Madá, SRD, fêmea, 9 anos, pelagem branca e preta, castrada. Histórico de êmese esporádica e emagrecimento. Foi levada ao atendimento para exames de rotina após a contactante vir a óbito por doença renal. A ultrassonografia abdominal apresentou alteração morfológica e os exames 
laboratoriais acusaram alteração na creatinina sérica $(2,7 \mathrm{mg} / \mathrm{dl}$ no atendimento inicial) e baixa densidade urinária. $\mathrm{O}$ animal foi classificado com DRC estágio 3.

Animal 3E: Bombom, SRD, fêmea, 6 anos, pelagem tricolor, castrada. Histórico de episódios eméticos e possibilidade de ingestão de planta tóxica ou corpo estranho. Um exame ultrassonográfico foi solicitado e constatado alteração na morfologia renal. Demais exames foram solicitados e não apresentavam alterações. Devido a alteração morfologia, o animal foi classificado como estágio 1 da DRC.

Animal 4E: Bibito, SRD, macho, 7 anos, pelagem branca e preta, castrado. Histórico de poliúria e polidipsia com início há cerca de 3 meses. Realizado exames de triagem para doenças endócrinas e DRC e ultrassonografia abdominal, a qual constatou alterações na morfologia renal. A urinálise apresentou baixa concentração urinária. $\mathrm{O}$ animal foi classificado como estágio 1 da DRC.

Animal 5E: Bob, SRD, macho, 8 anos, pelagem branca, castrado. Histórico de cegueira súbita e dilatação de pupilas. Constatado hipertensão arterial sistêmica, alteração morfológica renal, creatinina inicial 2,0 mg/dl, sendo classificado como DRC estágio 2. No momento de adesão ao experimento, apresentava PAS $140 \mathrm{~mm} \mathrm{Hg}$ (dentro da normalidade), medicado com anlodipina, na dose de $0,650 \mathrm{mg} / \mathrm{q} 24 \mathrm{~h}$. O animal recebeu a aplicação de célulastronco renais, porém a tutora não compareceu aos retornos estipulados e 0 animal foi excluído do estudo.

\section{Grupo Controle}

Animal 1C: Sherry, SRD, fêmea, 7 anos, pelagem branca e marrom, castrada. O animal havia sido recentemente adotado tutor o levou ao atendimento para a realização de exames de rotina, foi constatado creatinina 1,9 $\mathrm{mg} / \mathrm{dl}$. Demais exames foram realizados e constatado alteração na morfologia renal. A creatinina foi recoletada em jejum, previamente ao experimento $(1,6$ $\mathrm{mg} / \mathrm{dl}$ ) e o animal foi classificado como DRC estágio 1.

Animal 2C: Lilica, SRD, fêmea, 8 anos, pelagem preta, castrada. Histórico de DRC diagnosticada há 3 meses. Apresentou alteração morfológica renal, 
baixa densidade urinária e creatinina $4,1 \mathrm{mg} / \mathrm{dl}$, sendo classificada como DRC estágio 3.

Animal 3C: Ceso, SRD, macho, 9 anos, castrado, pelagem amarela. $O$ animal realizou exames de rotina em uma clínica particular, onde foi constatado elevação nos níveis séricos de creatinina e foi encaminhado ao Hovet UNISA para acompanhamento do quadro e realização de demais exames. Foi constatado alteração na morfologia renal, baixa densidade urinária e creatinina 2,57 mg/dl, sendo classificado como DRC estágio 2.

Animal 4C: Sula, SRD, fêmea, 7 anos, pelagem cinza, castrada. Histórico de poliúria, polidipsia há cerca de 1 mês. Apresentou alterações na ultrassonografia renal, baixa densidade urinária e creatinina 2,8 $\mathrm{mg} / \mathrm{dl}$, sendo classificada como estágio 3 da doença. A tutora remarcou por duas vezes a data de aplicação do experimento e previamente ao dia estipulado, o animal iniciou um quadro neurológico central agudo e foi excluído do estudo devido a possibilidade de doença concomitante.

\subsection{SUPORTE NUTRICIONAL E TERAPÊUTICO}

Os animais eram alimentados com dieta comercial para gatos adultos. Alterações na dieta não foram realizadas para que não ocorresse interferência no estudo. $\mathrm{O}$ animal $3 \mathrm{C}$ não aceitou a troca para alimentação terapêutica renal, prescrita após o primeiro atendimento.

Os animais 3E, 4E, 1E, 1C e $2 \mathrm{C}$ não fizeram o uso sprotocolo terapêutico durante o período de experimento.

O animal 2E estava medicado com omeprazol $1 \mathrm{mg} / \mathrm{kg} / \mathrm{q} 12 \mathrm{~h}$, mirtazapina $1,88 \mathrm{mg} / \mathrm{q} 48 \mathrm{~h}$ e realizava fluidoterapia subcutânea, $100 \mathrm{ml}, 2$ vezes por semana. O animal 2C estava medicado com mirtazapina 1,88 mg/q48h, hidróxido de alumínio, 90mg/kg/dia, com a alimentação e fluidoterapia subcutânea com Ringer com lactato, $100 \mathrm{ml}$, duas vezes por semana.

\subsection{APLICAÇÃO INTRAPERITONEAL DAS CPRs.}

A aplicação das células-tronco renais foi realizada pela via intraperitoneal. 
O seguinte procedimento foi estabelecido (Figura 4A):

1 - Posicionamento em decúbito dorsal e contenção manual;

2 - Tricotomia da região abdominal.;

3 - Antissepsia com solução de clorexidina alcoólica $0,5 \%$;

4 - Avaliação ultrassonográfica no sítio de aplicação;

5 - Inserção do cateter 24G na linha alba da região mesogástrica, dois (2) centímetros abaixo da cicatriz umbilical;

6 - Aplicação de células-tronco renais ou placebo, previamente diluídas em $3 \mathrm{ml}$ de PBS.

Os animais demonstraram boa tolerância com a contenção e decúbito, não sendo necessário a utilização de protocolos de sedação. A aplicação de CPRs ou placebo foi realizada sem intercorrências na região mesogástrica. Nenhum dos animais apresentava distensão de órgãos ocos ou aumento de órgãos parenquimatosos no momento da aplicação. O procedimento teve duração de total de 5 minutos, após a contenção dos animais. A manipulação e diluição das CPRs ou placebo foi realizada com material estéril. 
Figura 4: Aplicação intraperitoneal de células progenitoras renais em gatos com doença renal crônica
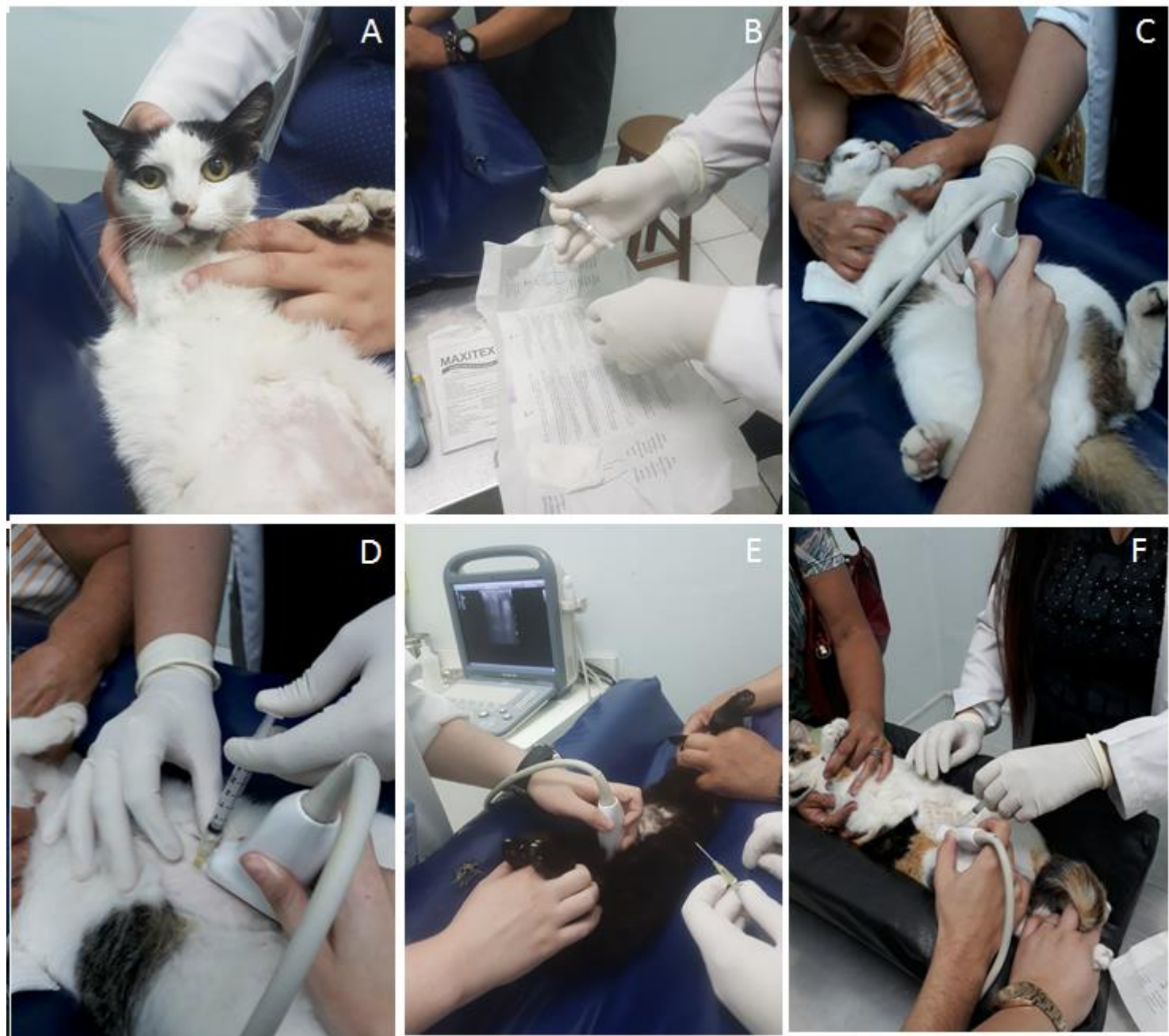

Fonte: NHANHARELLI, J. P. (2018)

Legenda: A - Animal 4E, felino, macho, SRD, 6 anos. Contenção em decúbito dorsal, com região ventral do abdômem tricotomizada; B - Manejo das CPRs com luva e materiais estéreis; C Acesso guiado por ultrassom da cavidade abdominal. Nota-se que mesmo após a inserção do cateter, o animal permanece tranquilo e com pouca contenção; D - Aplicação de CPRs pela via intraperitoneal; E e F - Animais 1E e 3E com contenção manual, realizada pelos tutores. 


\subsection{AVALIAÇÃO CLINICA DOS ANIMAIS}

6.5.1 Avaliação após a aplicação de células-tronco ou placebo

Os animais foram monitorados após a aplicação das células ou placebo para avaliação de possíveis efeitos colaterais ou reações. Os parâmetros de frequência cardíaca, frequência respiratória, pressão arterial sistólica e temperatura foram monitorados antes da aplicação, 10 e 20 minutos após. Os animais foram mantidos com os tutores e sem contenção. Nenhum dos animais apresentaram dor ou desconforto abdominal à palpação. Os resultados dos parâmetros avaliados estão demonstrados no gráfico abaixo (Gráfico 1). 
Gráfico 1 - Parâmetros fisiológicos dos animais avaliados antes e após aplicação de células progenitoras renais ou placebo, pela via intraperitoneal
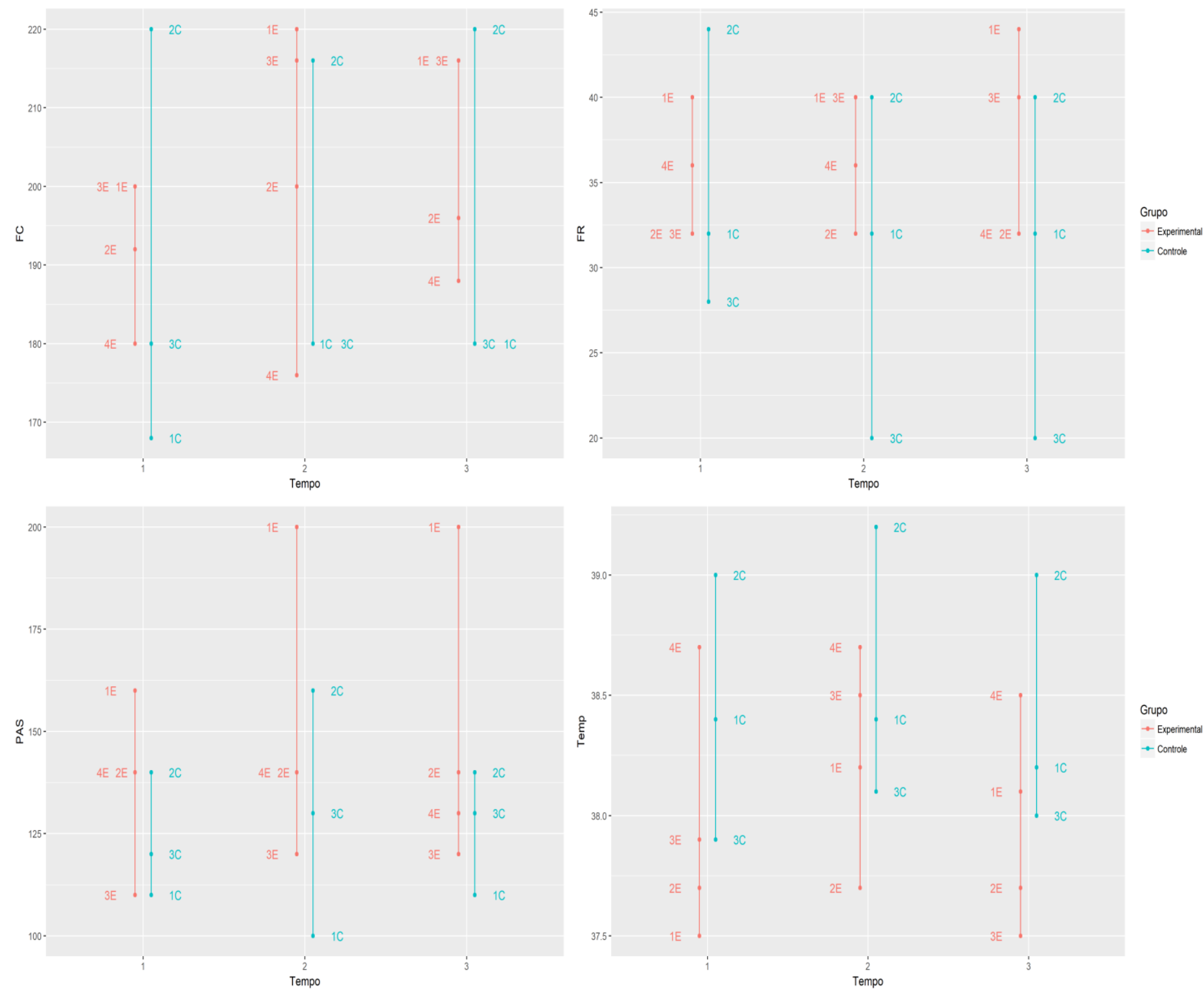

Fonte: NHANHARELLI, J. P. (2018)

Legenda: FC - frequência cardíaca; FR - Frequência respiratória; PAS - pressão arterial sistólica; Temp - temperatura. Tempo 1 - antes da aplicação das CPRs ou placebo. Tempo 2 7 dias após o tratamento; Tempo 3 - 14 dias após o tratamento.

Não houve diferenças significativas nos parâmetros fisiológicos entre os animais do Grupo E e do Grupo C. Um dos animais do grupo E, o animal 1, apresentou um aumento importante da P.A.S., porém demonstrou-se estressado após contenção, dificultando a sua mensuração nos tempos 2 e 3 após a aplicação das CPRs. Os valores descritivos dos parâmetros mensurados estão na Tabela 5. 
Tabela 5: Parâmetros fisiológicos pré e pós aplicação de células-tronco renais ou placebo

T1

T2

T3

Parâmetro Referência Grupo A Grupo B Grupo A Grupo B Grupo A Grupo B

FC $\quad 160-240 \quad 193.00 \pm 9,45 \quad 189.33 \pm 27.23 \quad 203.00 \pm 19.97 \quad 192.00 \pm 20.78204 .00 \pm 14.24 \quad 193.33 \pm 23.09$

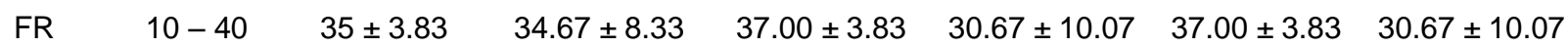

PAS $\quad 120-150137.50 \pm 20.62123 .33 \pm 15.28150 .00 \pm 34.64130 .00 \pm 30.00147 .50 \pm 35.94126 .67 \pm 15.28$

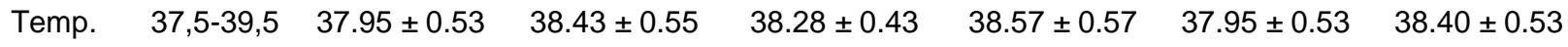

Fonte: NHANHARELLI, J. P. (2018)

Legenda: FC - frequência cardíaca; FR - Frequência respiratória; PAS - pressão arterial sistólica; Temp temperatura. Valores de referência ETTINGER (2010)

\subsubsection{Avaliação da terapia celular}

Os tutores foram questionados quando a ocorrência de manifestações clínicas durante todo o período de observação, nos dias D0, D7 e D14, descritas na Tabela 6.

Os animais 1E, 2E, 4E, 2C e 3C, apresentavam manifestações clínicas de poliúria e polidipsia antes do início do experimento e mantiveram essas alterações nos em D7 e D14. Houve melhora apetite e ingestão de alimentos dos animais 1E, 3E, 4E e o animal 3C no D7. Essas alterações permaneceram até o D14. Os animais 3E e 4E apresentaram também melhora da atividade e locomoção, permanecendo mais tempo ativos e em contato com os tutores.

O animal 1E, apresentou diarreia pastosa de coloração marrom claro, no dia seguinte a aplicação das células progenitoras renais, com resolução após 1 dia, sem necessidade de intervenção medicamentosa.

O animal 2E apresentou hiporexia 3 dias após a aplicação das CTPRs, a qual se estendeu até o D7. Após esse período o animal apresentou melhora e retornou gradualmente ao apetite normal no D14.

O animal 2C, manteve-se sem alterações clínicas no D7. No D14 foi referido pelo tutor a presença de prostração, hiporexia e êmese. 
Tabela 6: Manifestações clínicas apresentadas por gatos portadores de doença renal crônica antes e após serem tratados com células progenitoras renais ou placebo

\begin{tabular}{|c|c|c|c|c|c|c|}
\hline Tempo & \multicolumn{2}{|c|}{ D0 } & \multicolumn{2}{|c|}{ D7 } & \multicolumn{2}{|c|}{ D14 } \\
\hline & Grupo E & Grupo C & Grupo E & Grupo C & Grupo E & Grupo C \\
\hline Prostração & - & - & - & $1(33,3 \%)$ & - & $1(33,3 \%)$ \\
\hline Desidratação & & & $1(25 \%)$ & & & $1(33,3 \%)$ \\
\hline Hiporexia & - & - & $1(25 \%)$ & $1(33,3 \%)$ & - & - \\
\hline Poliúria & $3(75 \%)$ & $2(66,6 \%)$ & $3(75 \%)$ & $2(66,6 \%)$ & $3(75 \%)$ & $2(66,6 \%)$ \\
\hline Polidipsia & $3(75 \%)$ & $2(66,6 \%)$ & $3(75 \%)$ & 2 (66,6\%) & $3(75 \%)$ & $2(66,6 \%)$ \\
\hline Êmese & - & - & - & - & - & $1(33,3 \%)$ \\
\hline Diarreira & - & - & $1(25 \%)$ & - & - & - \\
\hline
\end{tabular}

Fonte: NHANHARELLI, J. P. (2018)

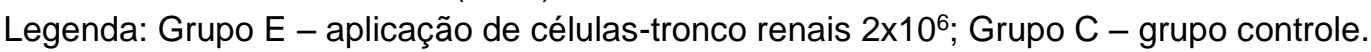
$\%$ porcentagem de animais afetados no grupo. 


\subsubsection{Pressão Arterial}

A pressão arterial sistólica foi mensurada com a utilização de um Doppler, por meio de 5 aferições consecutivas. O valor final foi obtido após a exclusão da primeira e última aferição e cálculo do valor médio entre as aferições realizadas. Os animais selecionados não apresentaram alterações na pressão arterial previamente a aplicação de células-tronco ou placebo. Em um dos animais do grupo experimental, o animal 1E, houve um aumento importante nos tempos $1 \mathrm{e}$ 2. O animal em questão possuía temperamento dócil, mas demonstrou inquietação durante a mensuração da P.A.S. O animal não tolerava bem a manipulação dos membros e assim como na monitoração após a aplicação das CPRs, permaneceu inquieto e estressado durante as aferições, o que pode ter interferido nos valores obtidos. As variações de pressão arterial entre os grupos, está demonstrada no Grafico 2.

Grafico 2 - Valores da Pressão Arterial Sistólica de gatos portadores de doença renal crônica, obtidas antes e após a aplicação de células progenitoras renais (CPRs) ou placebo.

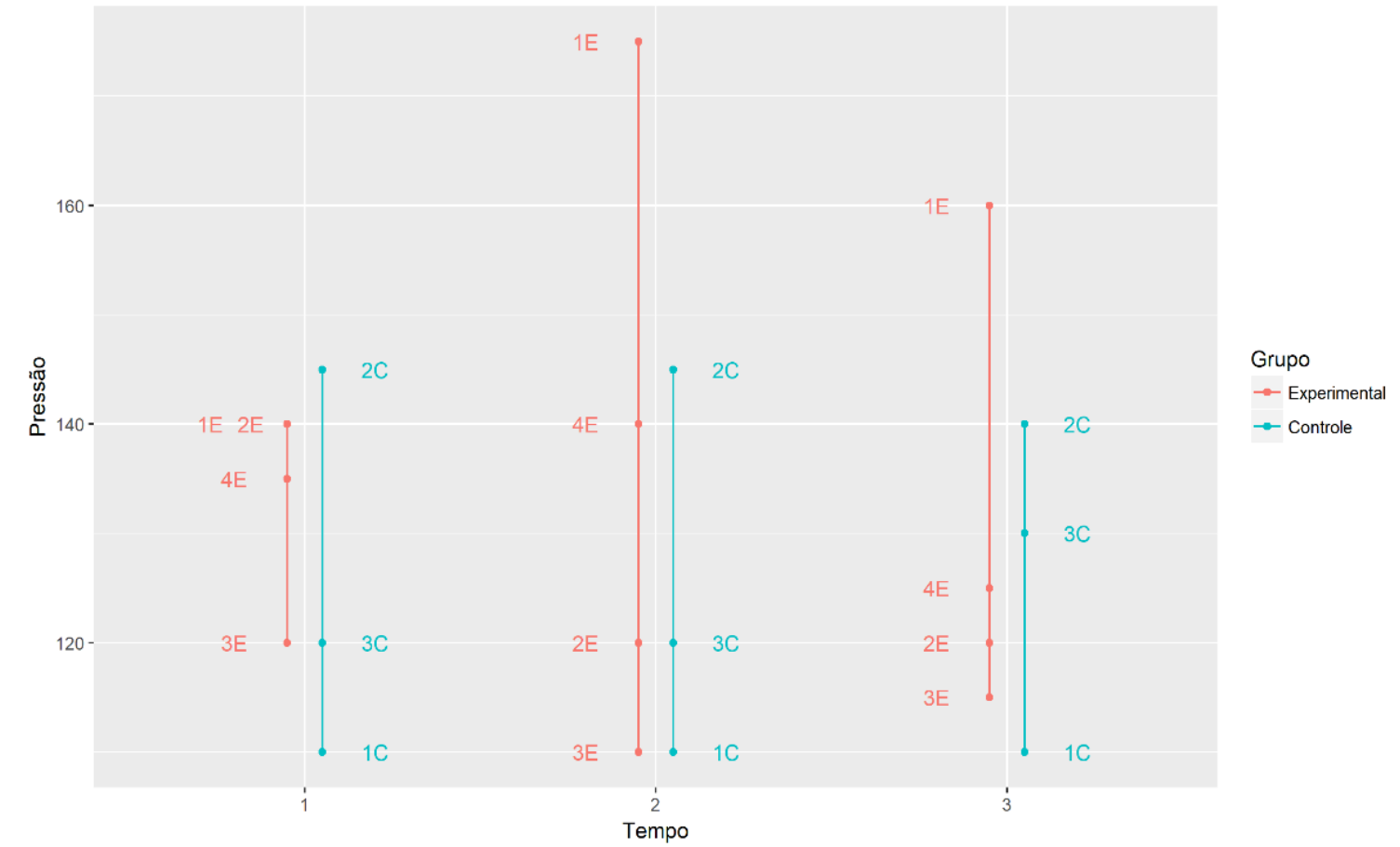

Fonte: NHANHARELLI, J. P. (2018)

Legenda: Tempo 1 - antes da aplicação das CPRs ou placebo. Tempo 2 - 7 dias após 0 tratamento; Tempo 3 - 14 dias após o tratamento. 


\subsubsection{Ganho de Peso}

Os animais 1E, 3E e 4E do grupo tratamento apresentaram ganho de peso de 3,8\%, 2,7\% e 2,3\%, respectivamente, em relação a avaliação anterior a aplicação das células-tronco (tempo 1) e após 14 dias (tempo 3). O animal 2E, do mesmo grupo apresentou perda $1,5 \%$ do peso corporal em relação ao mesmo período, mas na avaliação entre os tempos 2 e 3, o mesmo animal apresentou um ganho de peso de 6,7\%, indicando uma perda de peso entre os tempos $1 \mathrm{e}$ 2 , seguida de uma recuperação no tempo 3. No grupo controle, os animais $1 \mathrm{C} \mathrm{e}$ 3C não apresentaram variações do peso corpóreo e o animal $2 \mathrm{C}$ apresentou uma perda de 5,4\%. Apesar de clinicamente relevantes, não houve diferença estatística entre os grupos (Gráfico 3).

Grafico 3 - Avaliação do ganho de peso de gatos com doença renal crônica, antes e após a aplicação de células progenitoras renais (CPRs) ou placebo

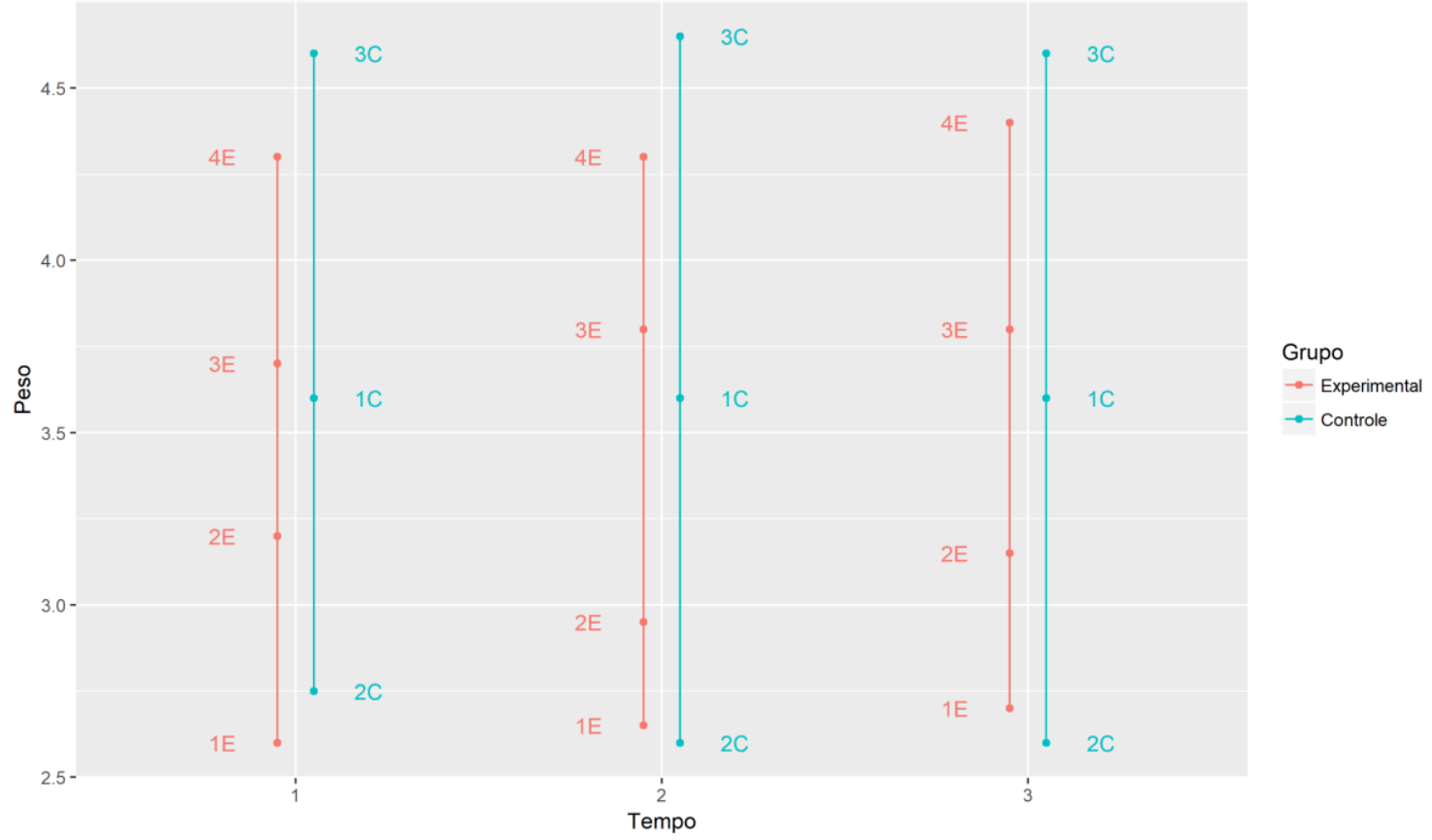

Fonte: NHANHARELLI, J. P. (2018)

Legenda: Tempo 1 - antes da aplicação das CPRs ou placebo. Tempo 2 - 7 dias após 0 tratamento; Tempo 3 - 14 dias após o tratamento. 


\subsection{AVALIAÇÃO LABORATORIAL}

\subsubsection{Exames hematológicos}

$\mathrm{Na}$ avaliação do hemograma, não houveram alterações no hematócrito e nos parâmetros hematimétricos entres os grupos. O valor dos leucócitos do grupo experimental foi significativamente menor $(p<0,02)$ do que os obtidos no grupo controle. Após a aplicação das CPRs (tempos 2 e 3), os animais apresentaram um aumento gradual dos valores de leucócitos. Os animais do grupo apresentaram pequenas variações nos valores dos leucócitos, exceto 0 animal 2C, o qual apresentou um amento no tempo 3. Nenhum dos animais, de ambos os grupos, apresentaram manifestações clínicas de infecção, febre e alterações na morfologia dos leucócitos.

Gráfico 4 - Valores de leucócitos totais de gatos domésticos com doença renal crônica, obtidos antes e após a aplicação de células progenitoras renais (CPRs) ou placebo.

Fonte: NHANHARELLI, J. P. (2018)

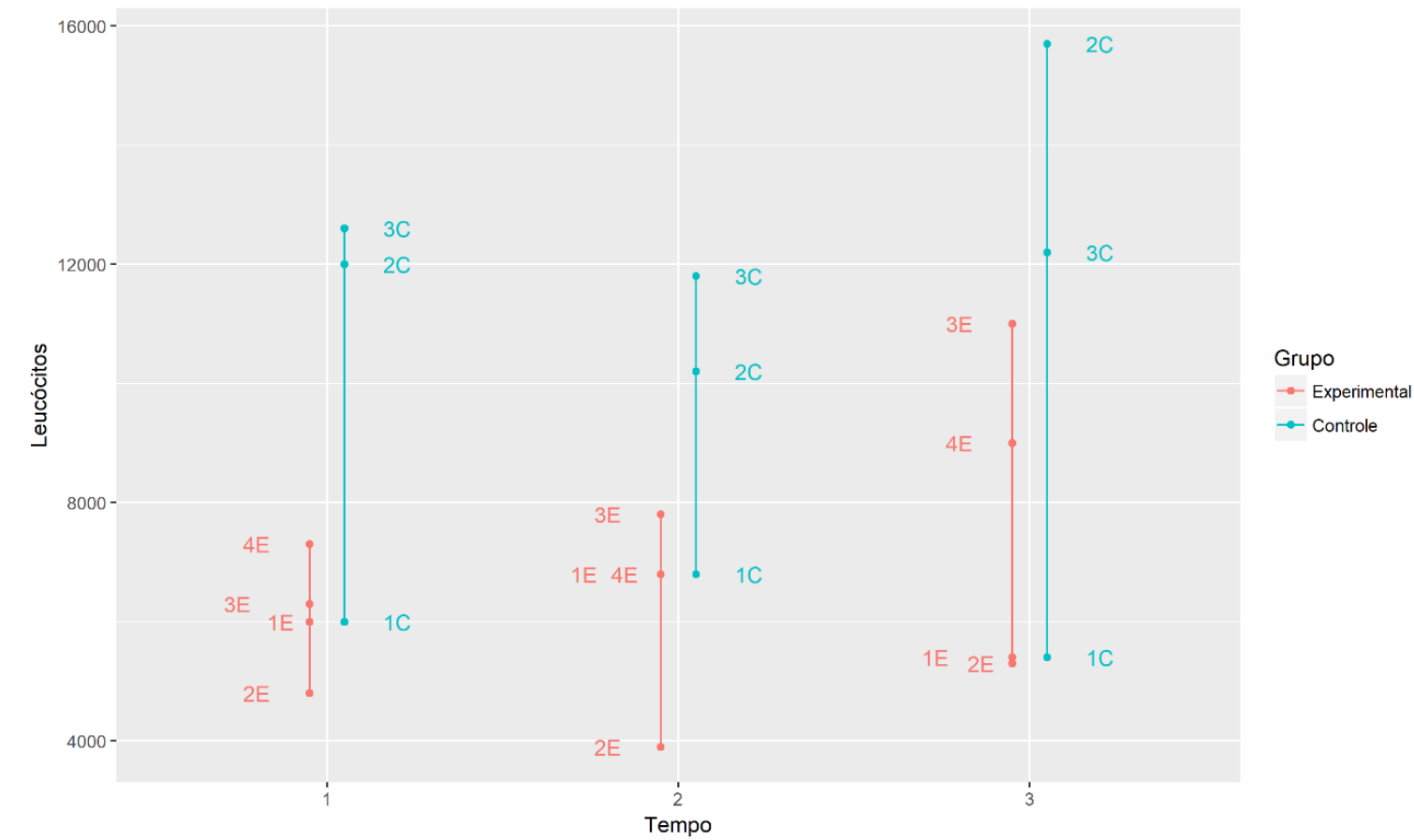

Legenda: Tempo 1 - antes da aplicação das CPRs ou placebo. Tempo 2 - 7 dias após o tratamento; Tempo 3 - 14 dias após o tratamento. 


\subsubsection{Creatinina}

Os valores de creatinina dos animais do grupo experimental apresentaram aumento, quando avaliados no tempo 1 em relação ao tempo 2. E apresentaram redução dos valores séricos, quando avaliados no tempo 1 em relação ao tempo 3. O animal $2 \mathrm{E}$, apresentou valores de creatinina sérica maiores do que os encontrados antes da aplicação das CPRs. No grupo controle, o animal $1 \mathrm{C}$ apresentou uma redução da creatinina nos tempos 2 e 3 . O animal 2C, apresentou um aumento gradual ao decorrer do período de avaliação. O animal 3C não apresentou alterações dos níveis de creatinina durante o período estudado. As variações nos valores de creatinina sérica, apresentaram um padrão semelhante nos animais do grupo experimental, mas foram pouco significativas do ponto de vista clínico e estatístico e estão descritas no Grafico 5.

Grafico 5 - Variações de creatinina sérica em gatos com doença renal crônica, obtidos antes e após a aplicação de células progenitoras renais (CPRs) ou placebo.

Fonte: NHANHARELLI, J. P. (2018)

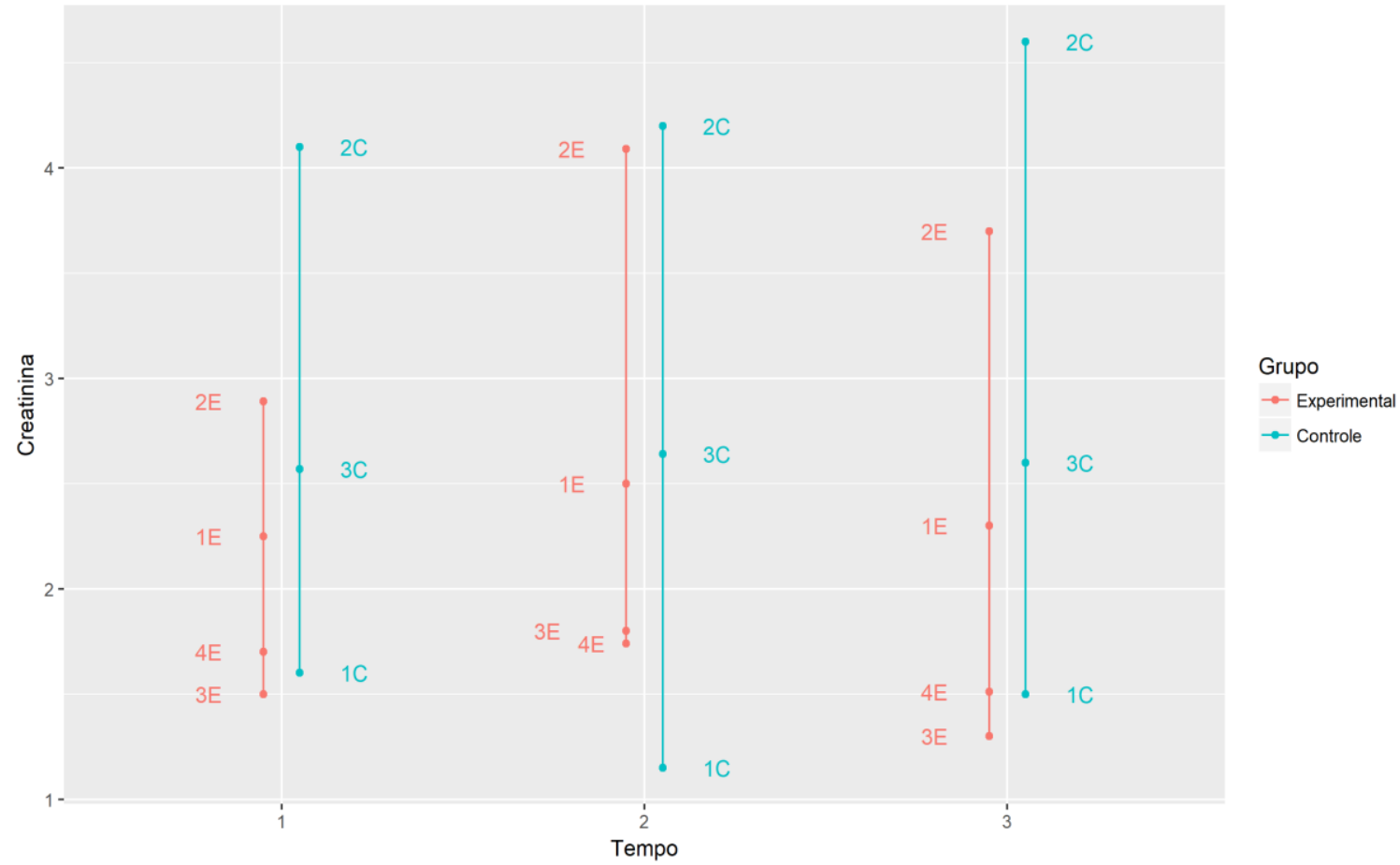

Legenda: Tempo 1 - antes da aplicação das CPRs ou placebo. Tempo 2 - 7 dias após 0 tratamento; Tempo 3 - 14 dias após o tratamento. 


\subsubsection{Ureia}

A ureia foi um dos parâmetros clínicos que mais apresentou variações durante o acompanhamento. Nos animais do grupo experimental houve um aumento dos níveis séricos de ureia entre os tempos 1 e 2, com redução discreta no tempo 3. Os animais $1 \mathrm{C}$ e $3 \mathrm{C}$, do grupo controle mantiveram os valores estáveis e o animal 2C apresentou um aumento importante desses valores, correlacionado às manifestações clínicas apresentadas, demonstradas na Tabela 5. As variações dos valores de ureia nos animais avaliados estão descritas no Gráfico 6

Grafico 6 - Variações de ureia sérica de gatos com doença renal crônica, obtidos antes e após a aplicação de células progenitoras renais (CPRs) ou placebo

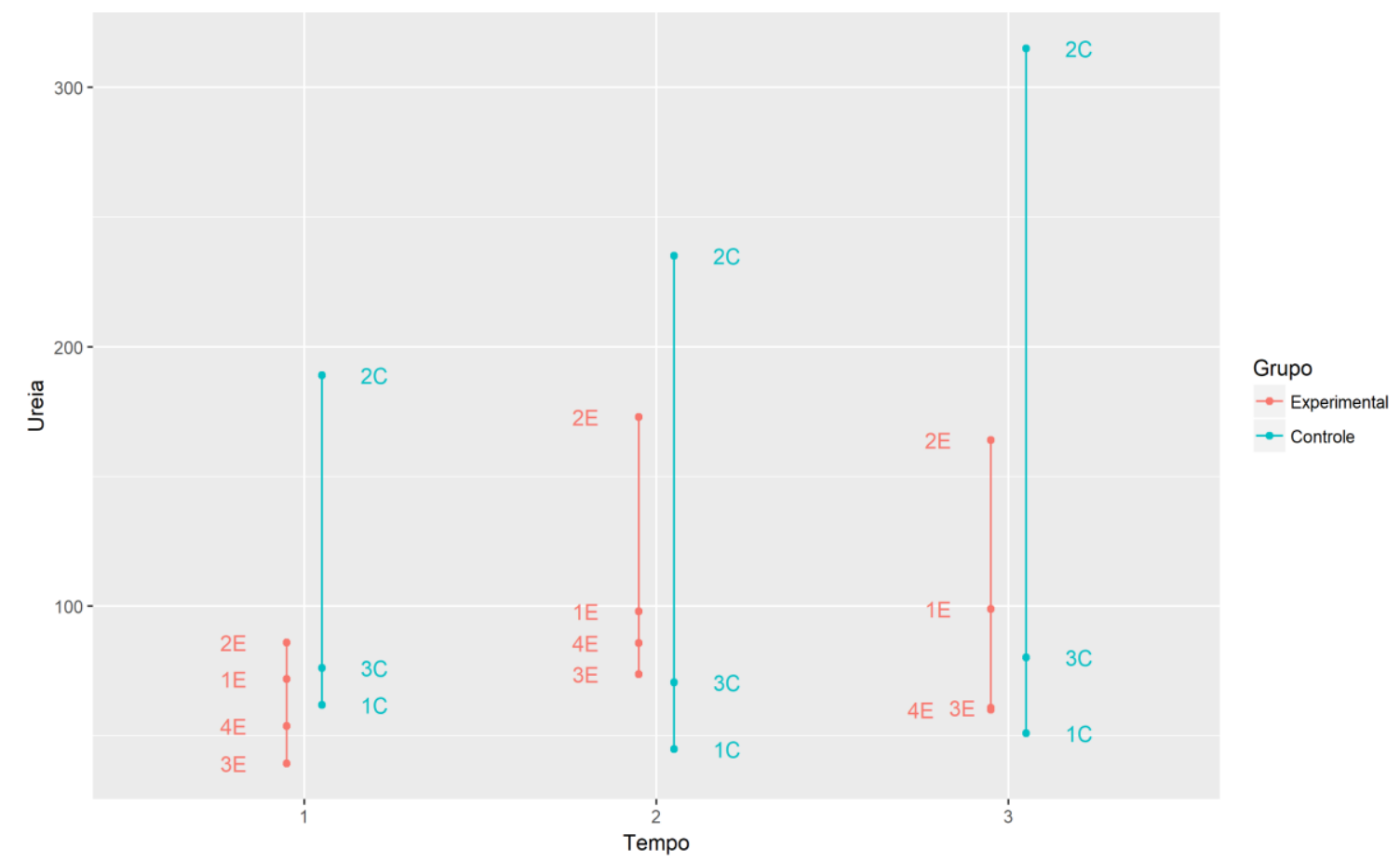

Fonte: NHANHARELLI, J. P. (2018)

Legenda: Tempo 1 - antes da aplicação das CPRs ou placebo. Tempo 2 - 7 dias após 0 tratamento; Tempo 3 - 14 dias após o tratamento. 


\subsubsection{Fósforo}

Houve aumento dos valores de fósforo do tempo 1 para o tempo $3 \mathrm{em}$ todos os animais do grupo experimental. Nos animais do grupo controle, o animal $1 \mathrm{C}$ apresentou redução gradual dos valores de fósforo sérico, enquanto o $3 \mathrm{C}$ se manteve com valores estáveis durante todo o período. $\mathrm{O}$ animal $2 \mathrm{C}$ apresentou também um aumento dos valores de fósforo. As variações dos valores do fósforo sérico estão descritas no Gráfico 6.

Grafico 7 - Variações de fósforo sérico de gatos com doença renal crônica, obtidos antes e após a aplicação de células progenitoras renais (CPRs) ou placebo.

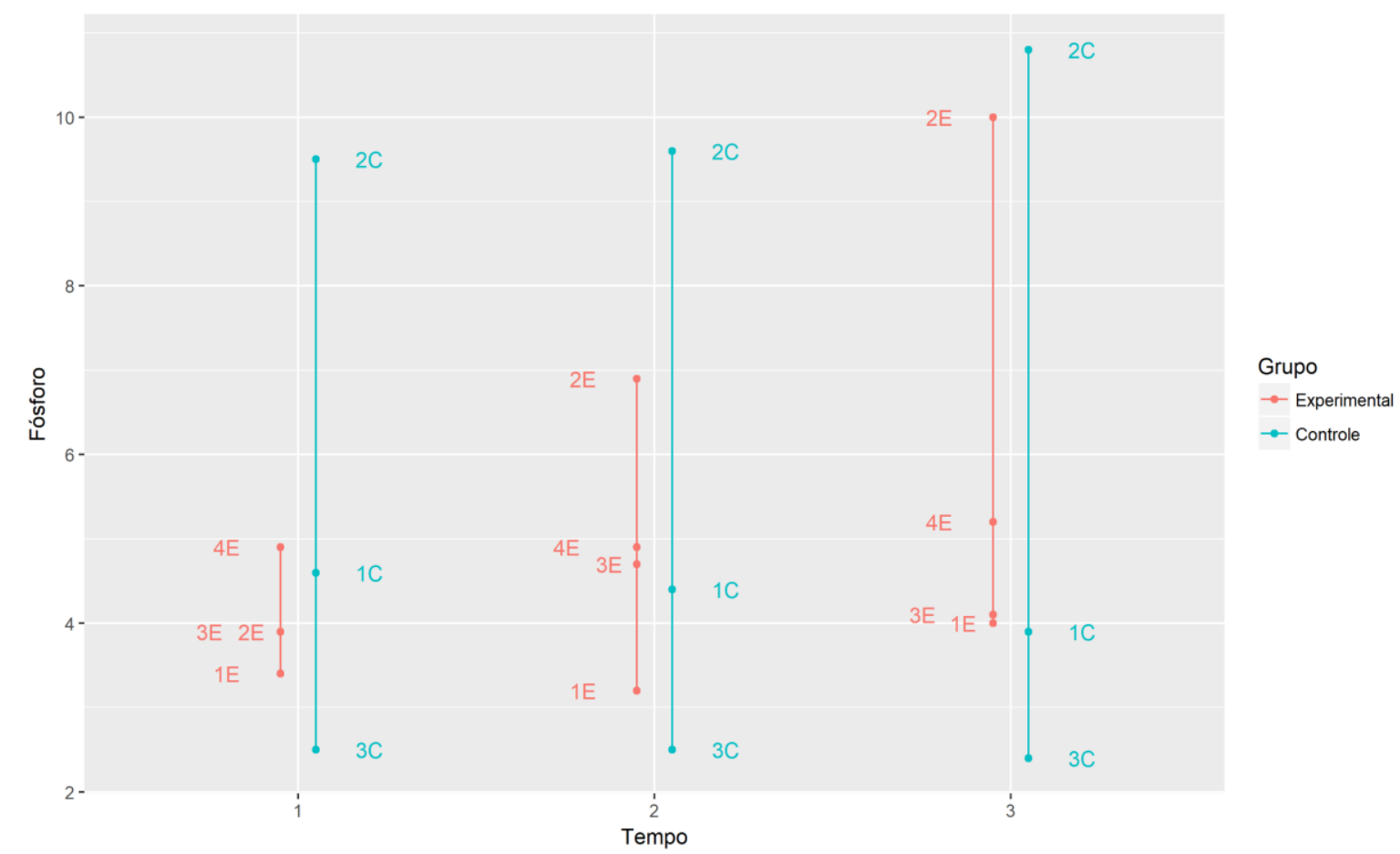

Fonte: NHANHARELLI, J. P. (2018)

Legenda: Tempo 1 - antes da aplicação das CPRs ou placebo. Tempo 2 - 7 dias após o tratamento; Tempo 3-14 dias após o tratamento. 


\subsubsection{SDMA}

$\mathrm{Na}$ avaliação do SDMA, três (3) dos animais do grupo experimental apresentaram uma redução dos valores, com exceção do animal $2 \mathrm{E}$, o qual apresentou aumento do marcador. Em contrapartida, todos os animais do grupo controle apresentaram elevação dos valores de SDMA, no mesmo período de tempo. Os valores não apresentaram significância estatística $(p=0.052)$, devido a variação individual do animal $2 \mathrm{E}$. Os valores e distribuição do SDMA estão descritos no Gráfico 7.

Grafico 8 - Variações de SDMA sérico de gatos com doença renal crônica, obtidos antes e após a aplicação de células progenitoras renais (CPRs) ou placebo

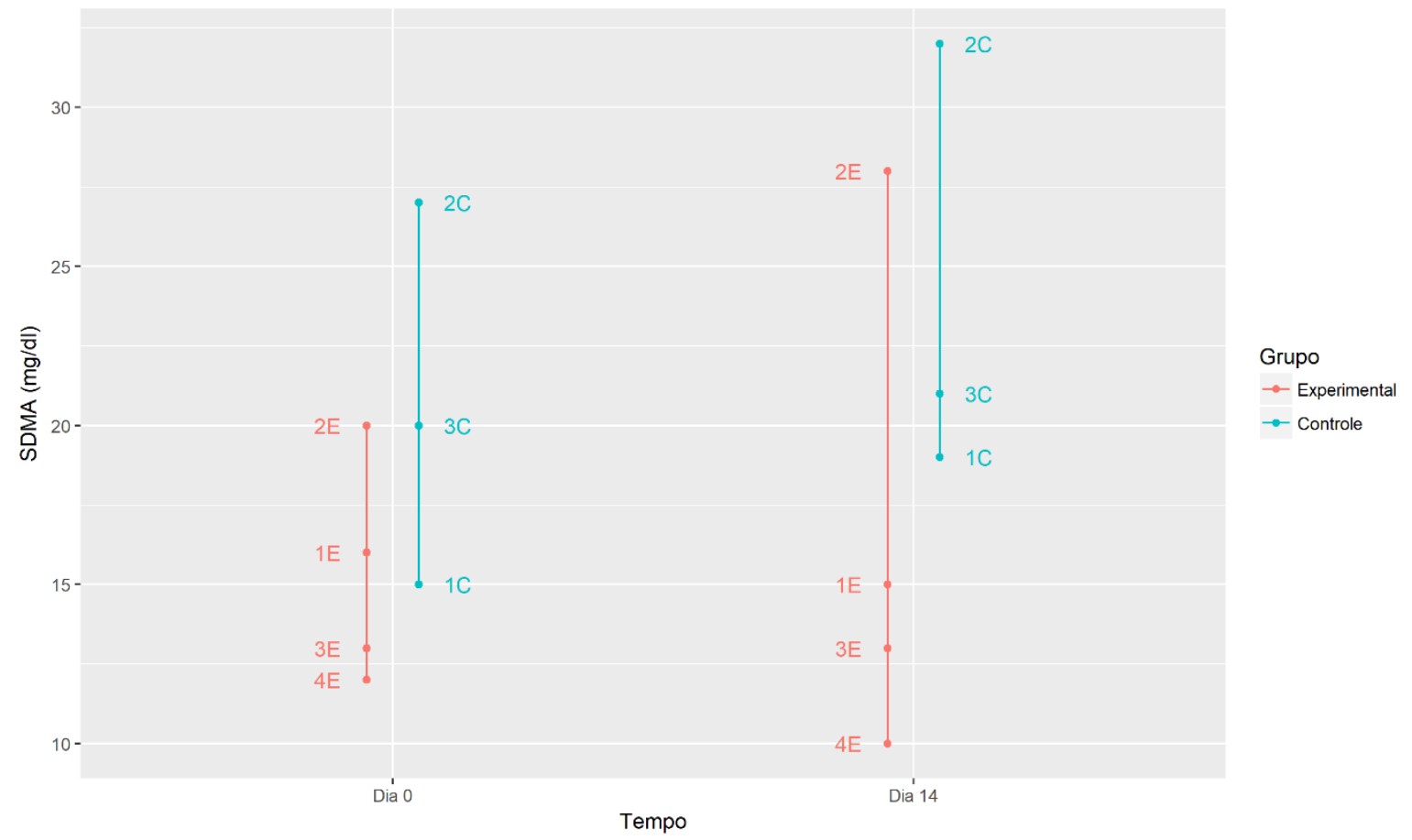

Fonte: NHANHARELLI, J. P. (2018)

Legenda: Dia 0 - antes da aplicação das CPRs ou placebo. Dia 14 - após o tratamento. 


\subsubsection{Urinálise}

Os animais $1 \mathrm{E}, 2 \mathrm{E}, 4 \mathrm{E}, 2 \mathrm{C}$ e $3 \mathrm{C}$ apresentavam uma redução da densidade urinária, correlacionada a clínica de poliúria apresentada pelos mesmos. Os animais 3E e 1C apesar de possuírem alterações morfológicas nos rins, não apresentaram alterações na densidade urinária. As amostras do D7 dos animais $1 \mathrm{E}$ e $2 \mathrm{C}$ não foram coletadas, pois os animais urinaram próximos ao horário de coleta. Os animais 2E, 4E, 1C e 3C apresentaram sedimento urinário ativo, com a presença de bactérias e detritos. Os animais avaliados eram assintomáticos quanto as manifestações clínicas do trato urinário inferior. A presença de sedimento ativo interfere na mensuração de proteinúria, portanto a avaliação desses animais não foi realizada. Nos animais que apresentaram sedimento urinário inativo, a avaliação foi realizada nos apenas nos animais 1E, 3E e $2 \mathrm{C}$ os quais não apresentaram proteinúria.

Grafico 9 - Variações na densidade urinária de gatos com doença renal crônica, obtidos antes e após a aplicação de células progenitoras renais (CPRs) ou placebo

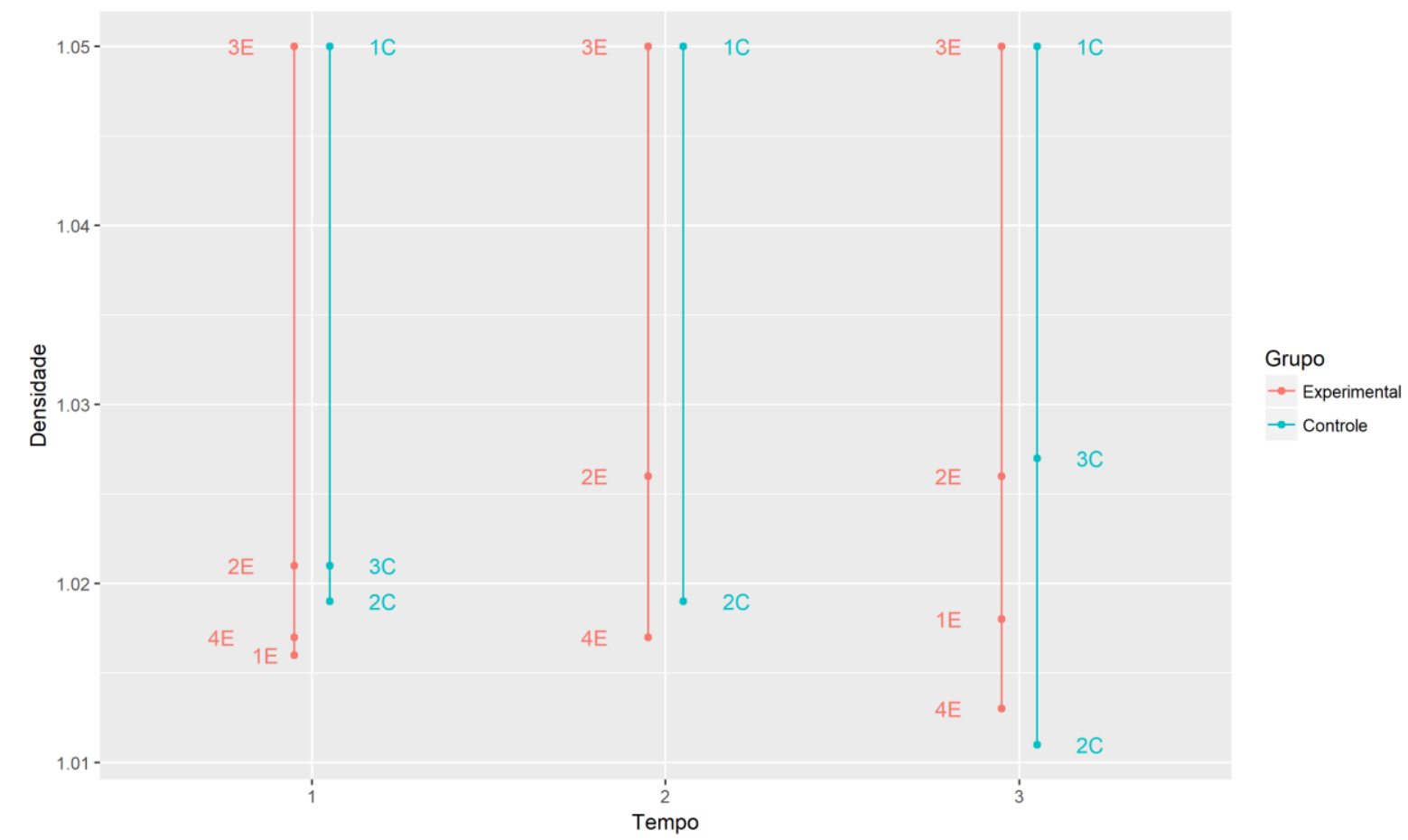

Fonte: NHANHARELLI, J. P. (2018)

Legenda: Tempo 1 - antes da aplicação das CPRs ou placebo. Tempo 2 - 7 dias após o tratamento; Tempo $3-14$ dias após o tratamento. 


\subsection{ULTRASSONOGRAFIA}

Todos os animais apresentavam alterações da morfologia renal na ultrassonografia abdominal. O principal achado foi redução do tamanho renal e diminuição da relação corticomeular. Não houve mudanças na estutura renal antes e após a aplicação das células progenitoras renais. As imagens ultrassonográficas dos animais afetados estão demontradas na Figura 5

Figura 5 - Alterações da morfologia renal de gatos com doença renal crônica
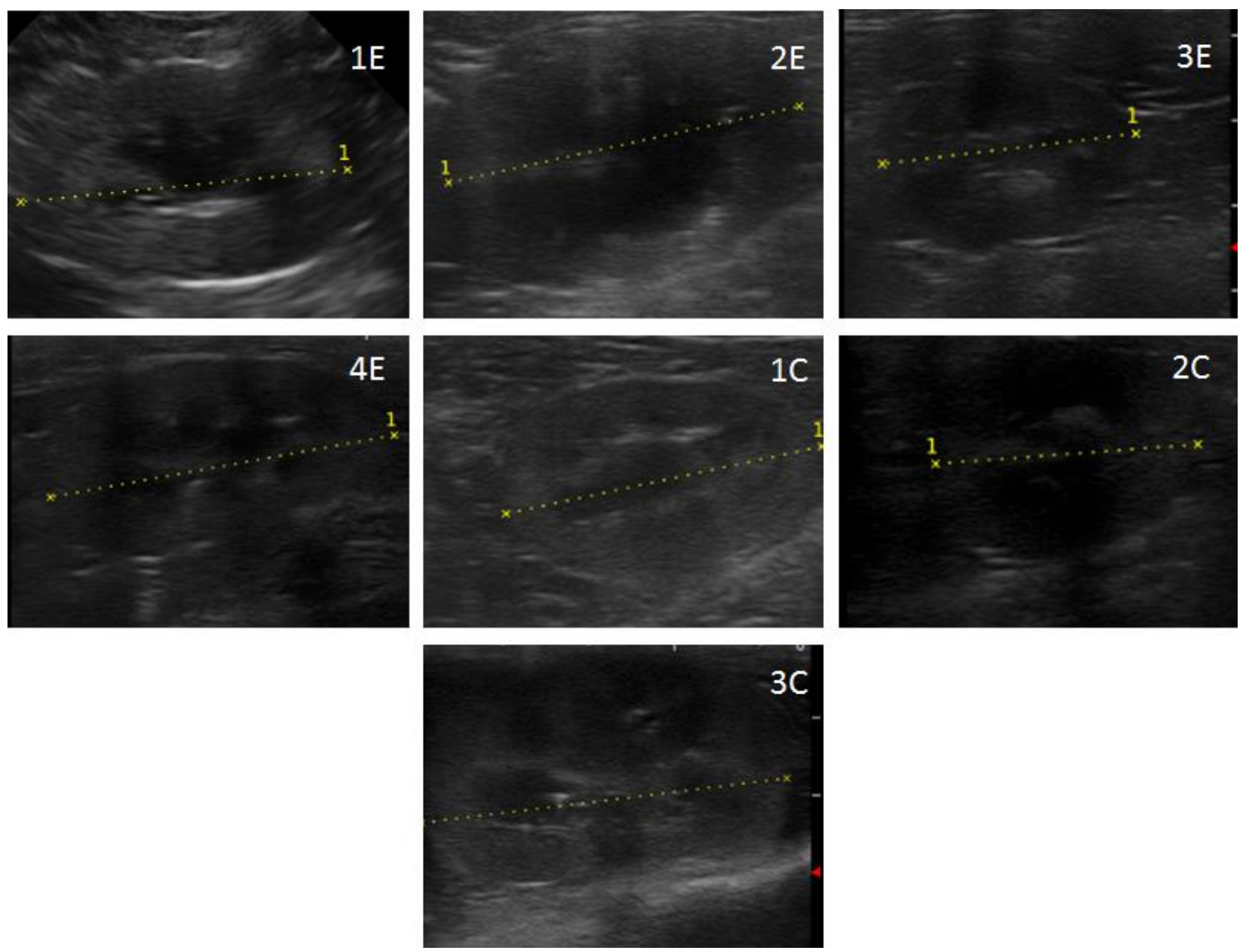

Fonte: NHANHARELLI, J. P. (2018)

Legenda: 1E, 2E, 3E - Rim esquerdo com dimensões reduzidas e redução da relação corticomedular; 4E - Rim contralateral com discreto aumento de tamanho e aumento da ecogenicidade cortical; 1C - Rim com dimensão reduzida, discreta perda da relaçaõ corticomedular e aumento da ecogenicidade; $2 \mathrm{C}$ - Rim com dimensão reduzida, perda da relação corticomedular e contornos irregulares; 3C Rim com diminuição da relação corticomedular. 


\section{DISCUSSÃO}

As células progenitoras renais utilizadas nesse estudo, caracterizadas por MARIO et al. (dados ainda não publicados), são células provenientes do tecido renal fetal, apresentam todas as características e marcadores de células mesenquimais - descritos por DOMINICI, et al (2006) - e marcadores específicos do tecido renal como a Nefrina e o Wt-1. Essas células também apresentam a marcação de c-kit+, como as células-tronco progenitoras renais descritas por Rangel et al, (2013). O isolamento de células-tronco de tecidos adultos, dão origem a uma linhagem celular multipotente. Outra importante característica apresentada pelas CPRs utilizadas, descrita por DOMINICl et al. (2006) e MARTIN et al. (2002), é a ausência da expressão de marcadores do complexo de histocompatibilidade principal, o MHC classe II, o qual é fundamental para os transplantes celulares alogênicos e confere segurança do ponto de vista imunológico, tendo em vista que a expressão desses marcadores podem induzir a rejeição do transplante celular e imunossupressão (ICHIRYU; FAIRCHILD, 2013).

Outra vantagem do transplante alogênico de células-tronco (CTs) na terapia da doença renal é a possibilidade de coleta isolamento de células a partir de indivíduos saudáveis. Sabe-se que a principal ação terapêutica das CTs é proveniente de sua ação parácrina, devido a liberação de vesículas celulares contendo material genético, fatores de crescimento tecidual e mediadores antifibróticos, inicialmente descritos por CAPLAN; DENNIS (2006). Em indivíduos urêmicos, essas características são afetadas. $\mathrm{NOH} \mathrm{OH}$ et al. (2010) demonstrou que as células-tronco urêmicas apresentaram menor expressão de fatores de crescimento, como o VEGF e maior senescência, quando comparadas com CTs derivadas de indivíduos saudáveis. A coleta de tecido para cultivo celular exige sedação do animal, o que pode ser uma desvantagem em animais debilitados.

A ação terapêutica das CTs sofre interferência da via de administração. A via mais utilizada é a endovenosa. Por essa via, grande parte das células são sequestradas pelos capilares pulmonares, esplênicos e hepáticos. Outra desvantagem é a possibilidade de efeitos pró-trombóticos, principalmente em números maiores de células-tronco, devido suas características de auto adesão. As vias intra-arterial e intra-renal apresentam menos riscos e menor sequestro 
capilar, mas necessitam de técnica adequada que muitas vezes são realizadas sob anestesia. Em gatos, o calibre das artérias periféricas dificulta a aplicação intra-arterial. No presente estudo, foi utilizada a via de aplicação intraperitoneal (IP), essa via foi descrita por vários autores na aplicação em modelos animais GAO et al. (2001), ELIOPULOS et al. (2010) e CHENG et al. (2013), e apresentaram efeitos benéficos quando comparada a aplicação intravenosa. $A$ vantagem da utilização dessa via para a administração de células-tronco, é a possibilidade de administração de um volume maior de células, sem causar eventos tromboembólicos, fácil acesso e um ambiente favorável a trocas imunológicas, a cavidade peritoneal, descrito por STOMMEL; STRIK; VANGOOR (2014). No presente estudo, a utilização da via IP em gatos foi tecnicamente efetiva e não apresentou efeitos adversos importantes a curto e médio prazo, com exceção de um animal, o qual apresentou diarreia com resolução espontânea ou alterações fisiológicas significativas após a aplicação, assim como descrito em outros modelos animais.

Um fator incerto sobre a aplicação de CTs na cavidade peritoneal é o tempo de ação. Estudos realizados por BARTOSH et al. (2013) demonstraram a permanência das células injetadas por essa via por cerca de uma semana, mas foram capazes de realizar recrutamento de células do sistema imune. As células são absorvidas por meio dos capilares do peritônio e capilares linfáticos presentes no mesentério.

A seleção dos animais foi realizada segundo os critérios de classificação da DRC proposto pela IRIS (2016). Foram inclusos gatos, portadores de DRC estágio 1 a 3 e quadro clínico estável, devido a interferência da uremia na ação das CTs.

A incidência da doença renal crônica é maior em animais idosos segundo LULICH et al. (1992), MARINO et al. (2014) e BARTGES (2012), principalmente após os 15 anos. Em contrapartida, os a porcentagem de animais nessa faixa de idade que morrem de DRC é de 13\%, segundo O'NEILL et al., (2015) e questiona-se se as alterações renais apresentadas podem ser um fator inerente ao envelhecimento e cursarem de forma diferente a DRC adquirida (BROWN; ELLIOTT; SCHMIEDT; BROWN, 2016). A seleção de animais com idades entre 5 e 10 anos permitiu a exclusão de animais com alterações morfofuncionais devido a senilidade e os animais com doença renal juvenil. 
Outro critério de inclusão utilizado foi a ausência de infecção pelos vírus da AIDS e leucemia felina (FIV e FeLV). POLI et al. (2012) conseguiram comprovar o envolvimento do vírus da FIV como um dos fatores envolvidos no desenvolvimento da DRC em felinos, causando deposição de imunocomplexos e inflamação dos glomérulos. Outro fato importante é que o efeito imunomodulatório das CTs podem favorecer a proliferação de infecções, principalmente as virais, por interferirem na modulação dos linfócitos, conforme descrito por FIERRO et al. (2017).

Os animais apresentaram alterações na ultrassonografia renal condizentes com a literatura, com perda de arquitetura interna renal, redução da relação cortico-medular, aumento da ecogenicidade das corticais, diminuição de tamanho e bordas irregulares.

Esses achados são condizentes com os descritos por SILVA, et al. (2008) e confirmam a existência de doença renal crônica nos animais estágio I, previamente as elevações de creatinina sérica.

A manifestação clínica mais descrita foi poliúria e polidipsia, presente em $70 \%$ dos animais avaliados ao decorrer do estudo, alguns dos animais apresentaram hiporexia (28\%), desidratação (28\%), prostração (14\%), perda de peso (14\%), êmese (14\%) e diarreia (14\%). Ambos animais no estágio 3 da doença, sendo um do grupo experimental e um do grupo controle, apresentaram mais manifestações clínicas do que os indivíduos nos estágios 1 e 2 , o que está de acordo com o descrito por LULICH et al (1992), BARTGES (2012), IRIS (2016).

Apenas 1 dos animais selecionados apresentava hipertensão arterial sistêmica prévia ao início do experimento e o mesmo foi excluído devido descontinuidade do tratamento. Um dos animais do grupo controle apresentou valores acima da normalidade após a aplicação de CPRs com 7 e 14 dias após a aplicação, porém tratava-se de um animal inquieto e não permissivo a manipulação dos membros. Hipertensão secundária ao estresse foi descrito por BROWN et al. (2007) e pode levar a erros diagnósticos. A avaliação dos órgãos alvo (rins, coração, cérebro e pulmão) pode auxiliar no diagnóstico, segundo IRIS (2016) assim como mensurações em casa ou com o mínimo de manipulação, para uma aferição fidedigna. 
Os animais do grupo experimental, apresentaram ganho de peso e melhora do apetite e ingestão de alimentos, em comparação ao grupo controle. Esses valores não foram estatisticamente significativos, mas apresentaram relevância clínica, principalmente devido ao ganho de peso ter ocorrido em um curto espaço de tempo e pela importância da manutenção do peso corporal no prognóstico e sobrevida da DRC. Segundo FREEMAN et al. (2015), os animais com maior peso corpóreo no momento do diagnóstico da DRC possuem maior longevidade quando comparado aos animais mais magros.

Os animais do grupo experimental apresentaram valores estatisticamente menores de leucócitos ( $p=0,02$ ), do que os animais do grupo controle e apresentaram aumento gradual 14 dias após a aplicação das CPRs, Um das possibilidades para as alterações nas contagens dos leucócitos são os efeitos imunomoduladores das CTs, descritos por FIERRO et al. (2017). Apesar das variações numéricas, nenhum dos animais apresentou manifestações clínicas de imunossupressão ou presença de focos infecciosos concomitantes.

A avaliação da relação proteína-creatinina urinária foi realizada apenas em dois animas, ambos não proteinúricos, devido a presença de sedimento urinário ativo na urina tipo I, com presença de bacteriúria, impossibilitando a análise da amostra. De acordo com LEES et al. (2005), a presença de sedimento urinário interfere nos valores de proteína e creatinina urinária, resultando em diagnósticos falso positivos. O tratamento com antibioticoterapia não é recomendado, segundo WEESE (2011), para animais assintomáticos com DRC e infecção do trato urinário (ITU). Outro fator importante para confirmação do diagnóstico de ITU, de acordo com esses autores, é a realização de cultura e antibiograma da urina. A densidade urinária dos animais de ambos os grupos não apresentou alterações antes e após o a aplicação de CPRs ou placebo.

Um fator interessante observado foi o aumento dos valores séricos de fósforo em todos os animais do grupo tratamento, apesar da manutenção dos valores séricos de creatinina e a redução dos valores de SDMA em 3 dos animais. Uma hipótese é o aumento de ingestão de fósforo na dieta e aumento da absorção intestinal, que é a principal via de absorção de fósforo no organismo, segundo ZATZ (2012). Os animais não faziam o uso de ração terapêutica e apenas um animal do grupo controle utilizava quelante de fósforo. O aumento foi mais notado nos animais doentes renais estágio 3 , em ambos os grupos. Os 
animais estágios 1 e 2 do grupo controle não apresentaram aumento dos valores, quando comparados ao tempo anterior.

A variação de creatinina entre os grupos não foi estatisticamente significativa, também observado por QUIMBY et al. (2016). Um fato a ser observado é que numericamente os animais do grupo experimental apresentaram uma elevação inicial dos níveis séricos, com pequenas variações, seguido de redução, após 15 dias de aplicação das células progenitoras renais. Dois animais do grupo controle não apresentaram variações nos valores de creatinina e um dos animais apresentou aumento importante do mesmo.

O SDMA é relatado na literatura como um marcador precoce da DRC e um marcador correlacionado a TFG (HALL, 2014; BRAFF et al., 2014). Três animais do grupo tratamento, apresentaram uma redução dos valores de SDMA, a qual não apresentou peso estatístico $(p=0,052)$ devido a variação individual do animal 2E. A redução dos valores de SDMA pode ser um indicativo de melhora na TFG, a qual não foi demonstrada nos valores de creatinina por ser um exame menos sensível. Os valores de SDMA dos animais avaliados não interferiram na classificação da IRIS (2016), permanecendo dentro dos valores estabelecidos para cada estágio em todos os indivíduos.

Mesmo com o grande avanço da terapia celular nos últimos anos, pouco se sabe do verdadeiro potencial para o tratamento de diversas doenças, principalmente as doenças crônicas. Na DRC, a fibrose renal aparenta ser um fator importante quanto a resposta ao tratamento com células-tronco, pois as mesmas realizam ação parácrina e necessitam de células viáveis para obterem um resposta regenerativa. Nos estudos com ratos, modelos de DRC 5/6, as células-tronco apresentam melhores resultados do que nos gatos com DRC adquirida, esse fato foi relatado por QUIMBY (2016), a qual também questionou se esse modelo de doença induzida pode ser comparado com animais em que o curso da doença evolui por anos. Muitos estudos ainda são necessários, mas a terapia celular continua sendo um grande potencial no tratamento da DRC. 


\section{CONCLUSÃO}

As células progenitoras renais, derivadas do metanefro de fetos de gato são seguras para a aplicação intraperitoneal e aparentam apresentar efeito parácrino quando utilizadas por essa via. Quanto ao efeito terapêutico, a melhora clínica e a redução dos valores de SDMA de 3 dos 4 animais tratados é um fator indicativo do potencial terapêutico das células. $O$ aumento do número de animais avaliados, limitação dos indivíduos aos estágios 1 e 2 da DRC, com menos fibrose tecidual e novos estudos ainda são necessários para estabelecer a viabilidade terapêutica das CPRs no tratamento da DRC, mas os resultados iniciais aparentam ser promissores. 


\section{REFERÊNCIAS BIBLIOGRÁFICAS}

ARATA, S.; OHMI, A.; MIZUKOSHI, F.; BABA, K.; OHNO, K.; SETOGUCHI, A.; TSUJIMOTO, $\mathrm{H}$. Urinary transforming growth factor- $\beta 1$ in feline chronic renal failure. The Journal of Veterinary Medical Science, v.67, n. 12, pp.1253-1255, 2005.

BARAL, R.M.; DHAND, N.K.; FREEMAN, K.P.; KROCKENBERGER, M.B.; GOVENDIR, MERRAN. Biological variation and reference change values of feline plasma biochemistry analytes. Journal of Feline Medicine and Surgery, v. 16, n. 4, pp 317-325, 2014.

BARTGES, J. W. Chronic Kidney Disease in Dogs and Cats. Veterinary Clinics of North America: Small Animal Practice, v. 42, n. 4, pp. 669-692, Jul. 2012.

BARTLETT, P.C.; VAN BUREN, J.W.; NETERER, M.; ZHOU, C. Disease surveillance and referral bias in the veterinary medical database. Preventive Veterinary Medicine, v. 94, n. 3, pp. 264-271, 2010.

BARTOSH, T.J.; YLOSTALO, J.H.; BAZHANOV, N.; KUHLMAN, J.; PROCKOP, D.J. Dynamic compaction of human mesenchymal stem/precursor cells into spheres self-activates caspase-dependent il1 signalling to enhance secretion of modulators of inflammation and immunity (PGE2, TSG6, and STC1). Stem Cells Reviews, v.31, n.11, pp.2443-2456, 2013.

BERNSTEEN, L.; GREGORY, C.R.; KYLES, A.E.; WOOLDRIDGE, J.D.; VALVERDE, C.R. Renal transplantation in cats. Clinical Techniques in Small Animal Practice, v. 15, n. 1, pp. 40-45, 2000.

BIJSMANS, E.S.; JEPSON, R.E.; CHANG, Y.M.; SYME, H.M.; ELLIOTT, J. Changes in systolic blood pressure over time in healthy cats and cats with chronic kidney disease. Journal of Veterinary Internal Medicine, v. 29, n. 3, p. 855861, 2015.

BRAFF, J.; OBARE, E.; YERRAMILLI, M.; ELLIOTT, J.; YERRAMILLI, M. Relationship between serum symmetric dimethylarginine concentration and glomerular filtration rate in cats. Journal of Veterinary Internal Medicine, v. 28, n. 6, p. 1699-1701, 2014.

BROWN, S.A.; BROWN, C.A. Single-nephron adaptations to partial renal ablation in cats. The American Journal of Physiology, v. 269, n. 5 (pt 2), Nov. 1995. 
BROWN, S.; ATKINS, C.; BAGLEY, R.; CARR, A.; COWGILL, L.; DAVIDSON, M.; EGNER, B.; ELLIOTT, J.; HENIK, R.; LABATO, M.; LITTMAN, M.; POLZIN, D.; ROSS, L.; SNYDER, P.; STEPIEN, R. Guidelines for the identification, evaluation, and management of systemic hypertension in dogs and cats. Journal of Veterinary Internal Medicine, v. 21, n. 3, p. 542-558, 2007.

BROWN, C. A.; ELLIOTT, J.; SCHMIEDT, C. W., \& BROWN, S. A. Chronic kidney disease in aged cats: clinical features, morphology, and proposed pathogeneses. Veterinary pathology, v. 53, n. 2, p. 309-326, 2016.

BUCKLEY, C.M.; HAWTHORNE. A.; COLYER, A.; STEVENSON, A.E. Effect of dietary water intake on urinary output, specific gravity and relative super saturation for calcium oxalate and struvite in the cat. The British Journal of Nutrition, v. 106, n. S1, pp. S128-S130, Oct. 2011.

BUSSOLATI, B.; BRUNO, S.; GRANGE, C.; BUTTIGLIERI, S.; DEREGIBUS, M.C.; CANTINO, D.; CAMUSSI, G. Isolation of renal progenitor cells from adult human kidney. The American Journal of Pathology, v. 166, n. 2, pp. 545-555, Feb. 2005.

CAPLAN, A. I.; DENNIS, J. E. Mesenchymal stem cells as trophic mediators. Journal of Cellular Biochemistry, v. 98, n. 5, pp. 1076-1084, 2006.

CARRADE, D.D.; AFFOLTER, V.K.; OUTERBRIDGE, C.A.; WATSON, J.L.; GALUPPO, L.D.; BUERCHLER, S.; KUMAR, V.; WALKER N.J.; BORJESSON, D.L. Intradermal injections of equine allogeneic umbilical cord-derived mesenchymal stem cells are well tolerated and do not elicit immediate or delayed hypersensitivity reactions. Cytotherapy, v. 13, n. 10, pp. 1180-1192, 2011.

CAVAGLIERI, R. C.; MARTINI, D.; SOGAYAR, M. C.; NORONHA, I. L. Mesenchymal stem cells delivered at the subcapsule of the kidney ameliorate renal disease in the rat remnant kidney model. Transplantation Proceedings, v. 41, n. 3, pp. 947-951, Apr. 2009.

CHAKRABARTI, S.; SYME, H.M.; ELLIOTT, J.; Clinicopathological variables predicting progression of azotemia in cats with chronic kidney disease. Journal of Veterinary Internal Medicine, v. 26, n. 2, pp. 275 - 281, 2012.

CHALHOUB, S.; LANGSTON, C.; EATROFF, A. Anemia of renal disease: what it is, what to do and what is new. Journal of Feline Medicine and Surgery, v. 13, n. 9, pp. $629-640,2011$. 
CHAMBERLAIN, G.; FOX, J.; ASHTON, B.; MIDDLETON, J. Concise review: mesenchymal stem cells: their phenotype, differentiation capacity, immunological features, and potential for homing. Stem Cells, v. 25, n. 11, pp. 2739-2749, 2007.

CHAN, D.L. The inappetent hospitalised cat: clinical approach to maximising nutritional support. Journal of Feline Medicine and Surgery, v. 11, n.11, pp. 925-933, 2009.

CHENG, K.; RAI, P.; PLAGOV, A.; LAN, X.; KUMAR, D.; SALHAN, D., GUPTA, $S$. Transplantation of bone marrow-derived MSCs improves cisplatinum-induced renal injury through paracrine mechanisms. Experimental and molecular pathology, v. 94, n. 3, p. 466-473, 2013.

COSTANTINI, F.; KOPAN, R. Patterning a complex organ: branching morphogenesis and nephron segmentation in kidney development. Developmental Cell, v. 18, n.5, pp. 698-712, 2010.

DA SILVA, V. C.; MAMPRIM, M. J.; VULCANO, L. C. Ultra-sonografia no diagnóstico das doenças renais em pequenos animais. Veterinária e Zootecnia, v. 15, n. 3, pp. 435-444, 2008.

DARBÈS, J.; MAJZOUB, M.; HERMANNS, W. Evaluation of the cross-reactivity between human and feline or canine leucocyte antigens using commercially available antibodies. Journal of Veterinary Diagnostic Investigation, v. 9, n. 1, pp. 94-97, 1997.

DIBARTOLA, S.P.; RUTGERS, H.C.; ZACK, P.M.; TARR, M.J. Clinicopathologic findings associated with chronic renal disease in cats: 74 cases (1973-1984). Journal of the American Veterinary Medical Association, v. 190, n. 9, pp. 1196-1202, 1987.

DOMINICI, M.; LE BLANC, K.; MUELLER, I.; SLAPER-CORTENBACH, I.; MARINI, F.; KRAUSE, D.; DEANS, R.; KEATING, A.; PROCKOP, D.; HORWITZ, E. Minimal criteria for defining multipotent mesenchymal stromal cells. The International Society for Cellular Therapy position statement. Cytotherapy, v. 8, n. 4, pp. 315-317, Jan. 2006.

DOW, S.W.; LECOUTEUR, R.A.; FETTMAN, M.J. SPURGEON, T.L Potassium depletion in cats: hypokalemic polymyopathy. Journal of the American Veterinary Medical Association, v. 191, n. 2, pp. 1563-1568, 1987.

ELIOPOULOS, N.; ZHAO, J.; BOUCHENTOUF, M.; FORNER, K.; BIRMAN, E.; YUAN, S.; BOIVIN, M.N.; MARTINEAU, D. Human marrow-derived mesenchymal stromal cells decrease cisplatin renotoxicity in vitro and in vivo and 
enhance survival of mice post-intraperitoneal injection. American Journal of Physiology-Renal Physiology, v. 299, n.6, pp. F1288-1298, 2010.

ELLIOTT, J.; BARBER, P. J. Feline chronic renal failure: clinical findings in 80 cases

diagnosed between 1992 and 1995. Journal of Small Animal Practice, v. 39, n. 2, pp. 78-85, Feb. 1998.

ELLIOTT, J.; SYME, H.M.; REUBENS, E.; MARKWELL, P.J. Assessment of acidbase status of cats with naturally occurring chronic renal failure. Journal of Small Animal Practice, v. 44, n.2, pp. 65-70, 2003.

ELLIOTT, D. A. Nutritional management of chronic renal disease in dogs and cats. Veterinary Clinics: Small Animal Practice, v. 36, n. 6, p. 1377-1384, 2006.

ETTINGER, S.J. The physical examination of the dog and cat. In: ETTINGER S.J., FELDMAN E.C. eds. Textbook of Veterinary Internal Medicine. 7th edition. St. Louis, MO: Saunders Elsevier, pp.1-9, 2010.

FAGOONEe, S.; PELliCANO, R.; SILENGo, L.; ALTRUDA, F. Potential applications of germline cell-derived pluripotent stem cells in organ regeneration. Organogenesis, v. 7, n.2, pp. 116-122, 2011.

FIERRO, F.A.; KO, E.M.; CLARK, K.C.; WALKER, N.J.; ARZI, B.; TEPPER, C.G.; DAHLENBURG, H.; CICCHETTO, A.; KOL, A.; MARSH, L.; MURPHY, W.J.; FAZEL, N.; BORJESSON, D.L.Human and feline adipose-derived mesenchymal stem cells have comparable phenotype, immunomodulatory functions, and transcriptome. Stem Cell Research Therapy, v.8, n.1, p. 69, 2017.

FINCH, N. C.; SYME, H. M.; ELLIOTT, J. The diagnostic utility of routine renal markers for predicting glomerular filtration rate (GFR). Proceedings of the BSAVA congress; 2013 April 4-7; Birmingham, England. p 569

FINCH, N. C.; SYME, H. M.; ELLIOTT, J. Parathyroid hormone concentration in geriatric cats with various degrees of renal function. Journal of the American Veterinary Medical Association, v. 241, n. 10, p. 1326-1335, 2012.

FOSTER, J.D. Update on mineral and bone disorders in chronic kidney disease. Veterinary Clinics: Small Animal Practice, v. 46, n. 6, p. 1131-1149, 2016.

FREEMAN, L.M.; LACHAUD, M.P.; MATTHEWS, S.; RHODES, L.; ZOLLERS, $B$. Evaluation of weight loss over time in cats with chronic kidney disease. Journal of Veterinary Internal Medicine, v. 29, p.1272, 2015. 
GALVAO, J. F.B.; NAGODE, L.A.; SCHENCK, P.A.; CHEW, D.J. Calcitriol, calcidiol, parathyroid hormone, and fibroblast growth factor-23 interactions in chronic kidney disease. Journal of Veterinary Emergency and Critical Care, v. 23, n. 2, p. 134-162, 2013.

GAO, J.; DENNIS, J.E.; MUZIC, R.F.; LUNDBERG, M.; CAPLAN, A.I. The dynamic in vivo distribution of bone marrow-derived mesenchymal stem cells after infusion. Cells, Tissues, Organs, v. 169, n. 1, pp. 12-20, 2001.

GEDDES, R. F.; ELLIOTT, J.; SYME, H. M. Relationship between plasma fibroblast growth factor-23 concentration and survival time in cats with chronic kidney disease. Journal of Veterinary Internal Medicine, v. 29, n. 6, p. 14941501, 2015.

GEDDES, R. F.; FINCH, N. C.; SYME, H. M.; ELLIOTT, J. The role of phosphorus in the pathophysiology of chronic kidney disease. Journal of Veterinary Emergency and Critical Care, v. 23, n. 2, p. 122-133, 2013.

GEST, J.; LANGSTON, C.; EATROFF, A. Iron status of cats with chronic kidney disease. J Journal of Veterinary Internal Medicine, v. 29, n. 6, pp. 1488-1493, 2015.

GOLDSTEIN, R.E.; MARKS, S.L.; KASS, P.H.; COWGILL, L.D. Gastrin concentrations in plasma of cats with chronic renal failure. Journal of the American Veterinary Medical Association, v. 213, n. 6, pp. 826-828, 1998.

HALL, J.A.; YERRAMILLI, M.; OBARE, E.; YERRAMILLI, M.; JEWELL, D.E. Comparison of serum concentrations of symmetric dimethylarginine and creatinine as kidney function biomarkers in cats with chronic kidney disease. Journal of Veterinary Internal Medicine, v. 28, n. 6, p. 1676-1683, 2014.

ICHII, O.; YABUKI, A.; SASAKI, N.; OTSUKA, S.; OHTA, H.; YAMASAKI, M.; TAKIGUCHI, M.; NAMIKI, Y.; HASHIMOTO, Y.; ENDOH, D.; KON, Y. Pathological correlations between podocyte injuries and renal functions in canine and feline chronic kidney diseases. Histology and Histopathology, v. 26, n. 10, pp. 1243-1255, 2011.

ICHIRYU, N.; FAIRCHILD, P. J. Immune privilege of stem cells. Embryonic Stem Cell Immunobiology: Methods and Protocols, p. 1-16, 2013.

IRIS. Staging System for Chronic Kidney Disease (CKD) Novartis Animal Health Inc., Basel 2010000 - 67, 2016. Disponível em: <http://www.iriskidney.com/guidelines/staging/>. Acesso em: jun. 2018. 
JEPSON, RE. Feline systemic hypertension: classification and pathogenesis. Journal of Feline Medicine and Surgery, v.13, n.1 pp.25-34, 2011.

KITAMURA, S.; YAMASAKI, Y.; KINOMURA, M.; SUGAYA, T.; SUGIYAMA, H., MAESHIMA, Y., \& MAKINO, H. Establishment and characterization of renal progenitor like cells from S3 segment of nephron in rat adult kidney. The FASEB Journal, v. 19, n. 13, p. 1789-1797, 2005.

KOBAYASHI, D. L. PETERSON, M. E.; GRAVES, T. K.; LESSER, M.; NICHOLS, C. E. Hypertension in cats with chronic-renal-failure or hyperthyroidism. Journal of Veterinary Internal Medicine, v. 4, n. 2, pp. 58-62, Mar-Apr. 1990.

KOGIKA, M.M.; LUSTOZA, M.D.; NOTOMI, M.K.; WIRTHL, V.A. ; MIRANDOLA, R.M ; HAGIWARA, M.K. Serum ionized calcium in dogs with chronic renal failure and metabolic acidosis. Veterinary Clinical Pathology, v. 35, n. 4, pp. 441-445, 2006.

KRAWIEC D, GELBERG H. Chronic renal disease in cats. Current Veterinary Therapy X, pp. 1170-1173, 1989.

KYLES, A. E.; HARDIE, M.; WOODEN, B. G.; ADIN, A.; STONE, E. A.; GREGORY, C. R.; MATHEWS, G.; COWGILL, L. D.; VADEN, S.; NYLAND, T. G.; LING, G. V. Clinical, clinicopathologic, radiographic, and ultrasonographic abnormalities in cats with ureteral calculi: 163 cases (1984-2002). Journal of the American Veterinary Medical Association, v. 226, n. 6, pp. 932-936, 2005.

LAI, R.C.; YEO, R.W.; LIM, S.K. Mesenchymal stem cell exosomes. Seminars in Cell \& Developmental Biology, v. 40, pp. 82-88, 2015.

LANGSTON, C. Managing fluid and electrolyte disorders in renal failure. The Veterinary Clinics of North America. Small Animal Practice, v. 38, n. 3, pp. 677-697, 2008.

LEE, R.H.; PULIN, A.A.; SEO, M.J.; KOTA, D.J.; YLOSTALO, J ; LARSON, B.L. ; SEMPRUN-PRIETO, L. ; DELAFONTAINE, P. ; PROCKOP, D.J. Intravenous hMSCs improve myocardial infarction in mice because cells embolized in lung are activated to secrete the anti-inflammatory protein TSG-6. Cell Stem Cell, v. 5, n. 1, pp. 54-63, 2009.

LEE, S.R.; LEE, S.H. ; MOON, J.Y. ; PARK, J.Y. ; LEE, D ; LIM, S.J. ; JEONG, K.H. ; PARK, J.K. ; LEE, T.W. ; IHM, C.G. Repeated administration of bone marrow-derived mesenchymal stem cells improved the protective effects on a remnant kidney model. Renal Failure, v. 32, n. 7, pp. 840-848, 2010. 
LEE, Y.J.; CHEN, H.Y. ; HSU, W.L. ; OU, C.M. ; WONG, M.L. Diagnosis of feline polycystic kidney disease by a combination of ultrasonographic examination and PKD1 gene analysis. The Veterinary Record, v. 167, n. 16, pp. 614-618, 2010.

LEES, G.E. ; BROWN, S.A. ; ELLIOTT, J ; GRAUER, G.E. ; VADEN, S.L. Assessment and management of proteinuria in dogs and cats: 2004 ACVIM Forum Consensus Statement (small animal). Journal of Veterinary International Medicine, v. 19, n.3, pp. 377-385, 2005.

LIU, Y. Cellular and molecular mechanisms of renal fibrosis. National Reviews Nephrology, v. 7, n. 12, pp. 684-696, 2011.

LULICH, J.P.; OSBORNE, C.A.; O'BRIEN, T.D.; POLZIN, D.J. Feline renal failure: questions, answers, questions. The Compendium on Continuing Education for the Practicing Veterinarian, v. 14, n. 2, pp. 127-152, 1992.

LYONS, L.A. ; BILLER, D.S. ; ERDMAN, C.A. ; LIPINSKI, M.J. ; YOUNG, A.E. : ROE, B.A. ; QIN, B. ; GRAHN, R.A. Feline polycystic kidney disease mutation identified in PKD1. Journal of the American Society of Nephrology, v. 15, n. 10, pp. 2548-2555, 2004.

MARINO, C.L. ; LASCELLES, B.D. ; VADEN, S.L. ; GRUEN, M.E. ; MARKS, S.L. Prevalence and classification of chronic kidney disease in cats randomly selected from four age groups and in cats recruited for degenerative joint disease studies. Journal of Feline Medicine and Surgery, v. 16, n. 6, pp. 465-472, 2014.

MARTIN, D.R. ; COX, N.R. ; HATHCOCK, T.L. ; NIEMEYER, G.P. ; BAKER, H.J. Isolation and characterization of multipotential mesenchymal stem cells from feline bone marrow. Experimental Hematology, v. 30, n. 8, pp. 879-886, 2002.

MARIO, L. C. et al. Desenvolvimento de células renais funcionais derivadas de mesonefro e metanefro de gato doméstico "in vitro". Tese de doutorado em andamento. Dados não publicados

MASUDA, S. ;YOKOO, T. ; SUGIMOTO, N. ; DOI, M. ; FUJISHIRO, S.H. ; TAKEUCHI, K. ; KOBAYASHI, E. ; HANAZONO, Y. A simplified in vitro teratoma assay for pluripotent stem cells injected into rodent fetal organs. Cell Medicine, vol. 3, no. 1-3, pp. 103-112, 2012.

MCLELAND, S.M. ; LUNN, K.F. ; DUNCAN, C.G. ; REFSAL, K.R. ; QUIMBY, J.M. Relationship among serum creatinine, serum gastrin, calcium-phosphorus product, and uremic gastropathy in cats with chronic kidney disease. Journal of Veterinary Internal Medicine, v. 28, n. 3, pp. 827-837, 2014. 
MISHINA, M. ; WATANABE, T. ; MAEDA, H. ; FUJII, K. ; WAKAO, Y. ; TAKAHASHI, M. ; EJIMA, H. Renal transplantation in cats with chronic renal failure. Journal of Veterinary Medical Science, v. 58, n. 7, pp. 655-658, 1996.

MORIGI, M.; IMBERTI, B.; ZOJA, C.; CORNA, D.; TOMASONI, S.; ABBATE, M.; ROTTOLI, D.; ANGIOLETTI, S.; BENIGNI, A.; PERICO, N.; ALISON, M.; REMUZZIM G. Mesenchymal stem cells are renotropic, helping to repair the kidney and improve function in acute renal failure. Journal of the American Society of Nephrology, v. 15, n. 7, p. 1794-1804, 2004.

NAKHOUL, G.N. ; HUANG, H. ; ARRIGAIN, S. ; JOLLY, S.E. ; SCHOLD, J.D. ; NALLY JR, J.V. , NAVANEETHAN, S.D. Serum Potassium, End-Stage Renal Disease and Mortality in Chronic Kidney Disease. American Journal of Nephrology, v. 41, n. 6, pp. 456-463, 2015.

O'NEILL, D.G. ; CHURCH, D.B. ; MCGREEVY, P.D. ; THOMSON, P.C. ; BRODBELT, D.C. Longevity and mortality of cats attending primary care veterinary practices in England. Journal of Feline Medicine and Surgery, v.17, n. 2, pp. 125-133, 2015.

O'NEILL, D.G. ; CHURCH, D.B. ; MCGREEVY, P.D. Prevalence of disorders recorded in cats attending primary-care veterinary practices in England. Veterinary Journal, v. 202, n. 2, pp. 286-291, 2014.

SCHENCK, P. A.; CHEW, D. J. Prediction of serum ionized calcium concentration by serum total calcium measurement in cats. Canadian Journal of Veterinary Research, v. 74, n. 3, p. 209-213, 2010.

POLI, A ; TOZON, N ; GUIDI, G ; PISTELLO, M. Renal alterations in feline immunodeficiency virus (FIV)-infected cats: a natural model of lentivirus-induced renal disease changes. Viruses, v. 4, n. 9, pp. 1372-1389, 2012.

POLZIN, D.J. Chronic kidney disease. In: BARTGES, J.; POLZIN D.J. Nephrology and urology of small animals. Wiley-Blackwell, pp. 433-471, 2011.

POLZIN, D. J. Evidence-based step-wise approach to managing chronic kidney disease in dogs and cats. Journal of Veterinary Emergency and Critical Care, v. 23, n. 2, pp. 205-215, 2013.

POLZIN, D.J.; CHURCHILL, J. A. Controversies in veterinary nephrology: renal diets are indicated for cats with international renal interest society chronic kidney disease stages 2 to 4: the pro view. Veterinary Clinics: Small Animal Practice, v. 46 , n. 6 , pp. 1049-1065, 2016. 
QUIMBY, J.M.; WEBB, T.L.; RANDALL, E.; MAROLF, A.; VALDES-MARTINEZ, A.; DOW, S.W. Assessment of intravenous adipose-derived allogeneic mesenchymal stem cells for the treatment of feline chronic kidney disease: a randomized, placebo-controlled clinical trial in eight cats. Journal of Feline Medicine and Surgery, v. 18, n. 2, pp. 165-171, 2016.

QUIMBY, J.M.; WEBB, T.L.; DOW, S.W.; GIBBONS, D.S. Evaluation of intrarenal mesenchymal stem cell injection for treatment of chronic kidney disease in cats: a pilot study. Journal of Feline Medicine and Surgery, v. 13, n. 6, pp. 418-426, 2011.

QUIMBY, J.M.; WEBB, T.L.; HABENICHT, L.M., DOW, S.W. Safety and efficacy of intravenous infusion of allogeneic cryopreserved mesenchymal stem cells for treatment of chronic kidney disease in cats: results of three sequential pilot studies. Stem Cell Research \& Therapy, v. 4, n. 2, pp. 48, 2013.

QUIMBY, J. M.; DOW, S. W. Novel treatment strategies for feline chronic kidney disease: A critical look at the potential of mesenchymal stem cell therapy. The Veterinary Journal, v. 204, n. 3, pp. 241-246, 2015.

QUIMBY, J. M. Update on medical management of clinical manifestations of chronic kidney disease. Veterinary Clinics: Small Animal Practice, v. 46, n. 6, p. 1163-1181, 2016.

QUIMBY, J.M.; LUNN, K.F. Mirtazapine as an appetite stimulant and anti-emetic in cats with chronic kidney disease: a masked placebo-controlled crossover clinical trial. Veterinary Journal,v.197, n. 3, pp. 651-655, 2013.

RANGEL, E.B.; GOMES, S.A.; DULCE, R.A.; PREMER, C; RODRIGUES, C.O.; KANASHIRO-TAKEUCHI, R.M.; OSKOUEI, B; CARVALHO, D.A.; RUIZ, P; REISER, J; HARE, J.M. C-Kit+ Cells Isolated from Developing Kidneys Are a Novel Population of Stem Cells with Regenerative Potential. Stem Cells, v. 31, n. 8, pp. 1644-1656, 2013.

REYNOLDS, B. S.; LEFEBVRE, H. P. Feline CKD: Pathophysiology and risk factors-what do we know? Journal of Feline Medicine and Surgery, v. 15, n. 1, pp. 3-14, 2013.

RIDEOUT, B. A.; MOORE, P. F.; PEDERSEN, N. C. Distribution of MHC class II antigens in feline tissues and peripheral blood. HLA, v. 36, n. 5, pp. 221-227, 1990. 
RINGDÉN, O.; UZUNEL, M.; RASMUSSON, I.; REMBERGER, M.; SUNDBERG, B.; LÖNNIES, H.; MARSCHALL, H.; DLUGOSZ, A.; SZAKOS, A.; HASSAN, Z.; OMAZIC, B.; ASCHAN, J.; BARKHOLT, L.; LE BLANC, K. Mesenchymal stem cells for treatment of therapy-resistant graft-versus-host disease. Transplantation, v. 81, n. 10, p. 1390-1397, 2006.

ROSS, L.A.; FINCO, D.R. Relationship of selected clinical renal function tests to glomerular filtration rate and renal blood flow in cats. American Journal of Veterinary Research, v. 42, n. 10, pp. 1704-1710, 1981.

ROSS, S.J.; OSBORNE, C.A.; KIRK, C.A.; LOWRY, S.R.; KOEHLER, L.A.; POLZIN, D.J. Clinical evaluation of dietary modification for treatment of spontaneous chronic kidney disease in cats. Journal of the American Veterinary Medical Association, v. 229, n. 6, pp. 949-957, 2006.

SEMEDO, P.; CORREA-COSTA, M.; ANTONIO CENEDEZE, M.; MARIA AVANCINI COSTA MALHEIROS, D.; ANTONIA DOS REIS, M.; SHIMIZU, M.H.; SEGURO, A.C.; PACHECO-SILVA, A.; SARAIVA CAMARA, N.O. Mesenchymal stem cells attenuate renal fibrosis through immune modulation and remodeling properties in a rat remnant kidney model. Stem Cells, v. 27, n. 12, pp. 30633073, 2009.

DE SOUSAI, S.R.; GALANTEI, N.Z.; BARBOSAII, D.A; PESTANAI, J.M.. Incidence of infectious complications and their risk factors in the first year after renal transplantation. Brazilian Journal of Nephrology, v. 32, n. 1, pp. 77-84, 2010.

STEPIEN, R.L. Blood pressure determination In: BARTGES, J.W.; POLZIN, D.J., editors. Nephrology and urology of small animals. Ames (IA): Wiley-Blackwell, .p. 86-90, 2011.

STOMMEL, M.W.; STRIK, C.; VAN GOOR, H. Response to pathological processes in the peritoneal cavity-sepsis, tumours, adhesions, and ascites. Seminars in Pediatric Surgery, v.23, n.6, pp. 331-335, 2014.

SYME, H.M. Proteinuria in cats. Prognostic marker or mediator? Journal of Feline Medicine and Surgery, v. 11, n. 3, pp. 211-218, 2009.

SYME, H. M.; MARKWELL, P.J.; PFEIFFER, D.; ELLIOTT, J. Survival of cats with naturally occurring chronic renal failure is related to severity of proteinuria. Journal of Veterinary Internal Medicine, v. 20, n. 3, pp. 528-535, 2006. 
TAUGNER, E.; BAATZ, G.; NOBILING, R. The renin-angiotensin system in cats with chronic renal failure. Journal of Comparative Pathology, v.115, n. 3, pp. 239-252, 1996.

THOMPSON, H. L.; MCLELLAND, B. T.; MANILAY, J. O. Indirect immune recognition of mouse embryonic stem cell-derived hematopoietic progenitors in vitro. Experimental Hematology, v. 42, n. 5, pp. 347-359, 2014.

TÖGEL, F.; WEISS, K.; YANG, Y.; HU, Z.; ZHANG, P.; WESTENFELDER, C. Vasculotropic, paracrine actions of infused mesenchymal stem cells are important to the recovery from acute kidney injury. American Journal of Physiology-Renal Physiology, v. 292, n. 5, p. 1626-1635, 2007.

TOLBERT, M. K., GRAHAM, A., ODUNAYO, A., PRICE, J., STEINER, J. M., NEWKIRK, K., \& HECHT, S. Repeated famotidine administration results in a diminished effect on intragastric $\mathrm{pH}$ in dogs. Journal of veterinary internal medicine, v. 31, n. 1, p. 117-123, 2017

VAN HOEK, I.; DAMINET, S. Interactions between thyroid and kidney function in pathological conditions of these organ systems: a review. General and Comparative Endocrinology,v. 160, n. 3, pp. 205-215, 2009.

VAN HOOF, M.; DE GEUS, J.P.; ROOS, M.; BROWN, C.; JACOBS, H.; PLOEGH, $\mathrm{H}$. The primary structure of a feline class I gene: Striking similarity to HLA-A. Immunogenetics, v. 30, n. 5, pp. 330-334, 1989.

VERLANDER, J. W. Fisiologia renal. CUNNINGHAM, JG Tratado de fisiologia veterinária, v. 3, 1999.

VIDANE, A.S.; PINHEIRO, A.O.; CASALS, J.B.; PASSARELLI, D.; HAGE. M.; BUENO, R.S.; MARTINS, D.S.; AMBRÓSIO, C.E.. Transplantation of amniotic membrane-derived multipotent cells ameliorates and delays the progression of chronic kidney disease in cats. Reproduction in Domestic Animals, pp. 316326, 2016.

VILLANUEVA, S.; CARREÑO, J.E.; SALAZAR, L.; VERGARA, C.; STRODTHOFF, R.; FAJRE, F.; CÉSPEDES, C.; SÁEZ, P.J.; IRARRÁZABAL, C.; BARTOLUCCI, J.; FIGUEROA, F.; VIO, C.P. Human mesenchymal stem cells derived from adipose tissue reduce functional and tissue damage in a rat model of chronic renal failure. Clinical Science, v. 125, n. 4, pp. 199-210, 2013.

WEESE, J.S.; BLONDEAU, J.M.; BOOTHE, D.; BREITSCHWERDT, E.B.; GUARDABASSI, L.; HILLIER, A.; LLOYD, D.H.; PAPICH, M.G.; RANKIN, S.C.; TURNIDGE, J.D.; SYKES, J.E. Antimicrobial use guidelines for treatment of 
urinary tract disease in dogs and cats: antimicrobial guidelines working group of the international society for companion animal infectious diseases. Veterinary Medicine International, 2011.

WEHNER, A.; HARTMANN, K.; HIRSCHBERGER, J. Associations between proteinuria, systemic hypertension and glomerular filtration rate in dogs with renal and nonrenal diseases. The Veterinary Record, v. 162, n. 5, pp. 141-147, 2008.

WEISS, D. J.; WARDROP, K. J. Schalm's veterinary hematology. John Wiley \& Sons, 2011.

WHITE, J.D; LEES, G.E. Congenital kidney disease. In: BARTGES, J.; POLZIN, D.J., editors. Nephrology and urology of small animals. Ames:Blackwell Publishing, pp. 568-576, 2011.

WHITE, J. D.; NORRIS, J.M.; BARAL, R.M.; MALIK, R. Naturally-occurring chronic renal disease in Australian cats: A prospective study of 184 cases. Australian Veterinary Journal, v. 84, n. 6, pp. 188-194, 2006.

WHITTEMORE, J.C.; HAWLEY, J.R.; JENSEN, W.A.; LAPPIN, M.R..Antibodies against Crandell Rees feline kidney (CRFK) cell line antigens, alpha-enolase, and annexin A2 in vaccinated and CRFK hyper inoculated cats. Journal of Veterinary Internal Medicine, v. 24, n. 2, pp. 306-313, 2010.

WILSON, T.; STARK, C.; HOLMBOM, J.; ROSLING, A.; KUUSILEHTO, A.; TIRRI, T.; PENTTINEN, R; EKHOLM, E. Fate of bone marrow-derived stromal cells after intraperitoneal infusion or implantation into femoral bone defects in the host animal. Journal of Tissue Engineering. 2010.

YABUKI, A.; MITANI, S.; FUJIKI, M.; MISUMI, K.; ENDO, Y.; MIYOSHI, N.; YAMATO, O. Comparative study of chronic kidney disease in dogs and cats: induction of myofibroblasts. Research in Veterinary Science, v. 88, n. 2, pp. 294-299, 2010.

YOKOTE, S.; YAMANAKA, S.; YOKOO, T.. De novo kidney regeneration with stem cells. Journal of Biomedicine and Biotechnology, v. 2012, 2012.

ZATZ, R. Fisiopatologia renal. Atheneu, 2002. 